\title{
DESEMPENHO FISIOLÓGICO DA CULTURA DE MILHO COM PLANTAS DE ARQUITETURA CONTRASTANTE: PARÂMETROS PARA MODELOS DE CRESCIMENTO
}

\section{MARCELO RIBEIRO ROMANO}

\author{
Tese apresentada à Escola Superior de Agricultura \\ "Luiz de Queiroz", Universidade de São Paulo, para \\ obtenção do título de Doutor em Agronomia, Área de \\ Concentração: Fitotecnia.
}

P I R A C I C A B A

Estado de São Paulo - Brasil

Janeiro - 2005 


\title{
DESEMPENHO FISIOLÓGICO DA CULTURA DE MILHO COM PLANTAS DE ARQUITETURA CONTRASTANTE: PARÂMETROS PARA MODELOS DE CRESCIMENTO
}

\section{MARCELO RIBEIRO ROMANO}

Engenheiro Agrônomo

Orientador: Prof. Dr. DURVAL DOURADO NETO

\begin{abstract}
Tese apresentada à Escola Superior de Agricultura "Luiz de Queiroz", Universidade de São Paulo, para obtenção do título de Doutor em Agronomia, Área de Concentração: Fitotecnia.
\end{abstract}

P I R A C I C A B A

Estado de São Paulo - Brasil

Janeiro - 2005 
Dados Internacionais de Catalogação na Publicação (CIP) DIVISÃO DE BIBLIOTECA E DOCUMENTAÇÃO - ESALQ/USP

\section{Romano, Marcelo Ribeiro}

Desempenho fisiológico da cultura de milho com plantas de arquitetura

contrastante: parâmetros para modelos de crescimento / Marcelo Ribeiro Romano. - Piracicaba, 2005.

100 p. : il.

Tese (Doutorado) - - Escola Superior de Agricultura Luiz de Queiroz, 2005.

Bibliografia.

1. Biometria 2. Crescimento vegetal 3. Dossel (Botânica) 4. Fisiologia vegetal 5. Fotossíntese 6. Milho - Produtividade 7. Radiação solar e terrestre I. Título

CDD 633.15 
A Deus, por me dar a vida e a mente e ainda me mostrar o caminho...

À minha amada esposa Anne e aos meus queridos filhos Amanda e Allan, pelo amor e confiança,

\section{Dedico.}

Aos meus pais Jorge e Mariza, em reconhecimento de todo o esforço para nunca nos faltar nada, principalmente amor,

\section{Ofereço.}




\section{AGRADECIMENTOS}

Ao Professor Dr. Durval Dourado Neto pela amizade, orientação, incentivo e pela sua sábia visão de futuro.

Ao Departamento de Produção Vegetal da ESALQ/USP, seus professores pelos valiosos ensinamentos e seus funcionários pelo apoio nos experimentos de campo.

Ao Professor Dr. Ricardo Ferraz de Oliveira, pelo apoio, disponibilização de mesa de estudo e dos equipamentos do laboratório de Fisiologia de Plantas Cultivadas Sob Condições de Estresse.

Ao Professor Dr. Paulo Augusto Manfron, de forma especial e grata, pela orientação e encaminhamento na carreira profissional de docência.

Ao Professor Dr. André Belmont Pereira, pela amizade, orientação e confiança no nosso trabalho.

A UEPG, pela oportunidade de trabalho e aperfeiçoamento profissional.

Aos colegas Mauro Guida dos Santos, Rafael Vasconcelos Ribeiro, Carlos Rodrigues Pereira, Oscar Dario Bermudez Zambrano, Miriam Ferraz Moreira, Gustavo Maia Souza, Camila do Prado Cenciani, Reinaldo Antônio Garcia Bonecarrére e Felipe Gustavo Pilau pela convivência, colaboração nos trabalhos e paciência.

A Sra. Luciane Aparecida Lopes, pela presteza e cordialidade na secretaria de pós-graduação em fitotecnia.

À Embrapa - Centro Nacional de Pesquisa de Milho e Sorgo, em especial ao Pesquisador Pedro Abel Vieira, pela recomendação e doação das sementes dos híbridos de milho pesquisados.

Ao Professor Dr. Marcos Bernardes, pelas orientações e empréstimo de equipamentos. 
Ao professor Dr. Edgar Gomes Ferreira de Beauclair, por ter nos selecionado no processo seletivo de ingresso ao curso de doutorado e pelo total apoio, confiança e compreensão.

À Coordenação de Aperfeiçoamento de Pessoal de Nível Superior (CAPES) pela bolsa concedida.

À bibliotecária Silvia, pelas correções da tese, paciência e boa vontade em solucionar problemas.

À Copiadora Luiz de Queiroz, pelos serviços de alta qualidade e principalmente pela simpatia de seus atendentes. 


\section{SUMÁRIO}

Página

LISTA DE SÍMBOLOS

viii

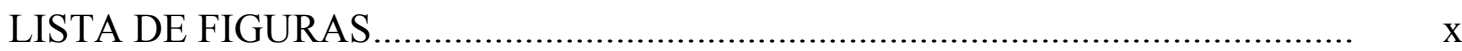

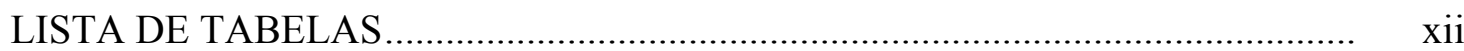



2 REVISÃO DE LITERATURA ….......................................................... 4

$2.1 \quad$ A cultura de milho ...................................................................................

2.1.1 Importância econômica e social................................................................. 4



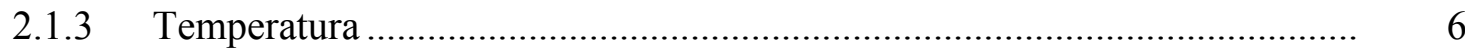

2.1.4 Radiação............................................................................................ 9

2.2 Arquitetura de parte aérea ........................................................................ 12

$2.3 \quad$ Efeitos do desfolhamento em milho ...................................................... 16

2.4 Assimilação de dióxido de carbono e eficiência quântica da fotossíntese.... 20

$2.5 \quad$ Modelagem em agricultura ......................................................................... 23

3 MATERIAL E MÉTODOS …........................................................... 28

3.1 Local e época de realização do experimento de campo ............................... 28

3.2 Genótipos utilizados............................................................................. 28

3.3 Delineamento experimental, dimensão de parcelas e população e distribuição de plantas............................................................................. 29

3.4 Condução do experimento de campo ........................................................ 29

3.5 Épocas de amostragem e estádios fenológicos ........................................... 31

3.6 Assimilação de dióxido de carbono, eficiência quântica da fotossíntese e respiração 
3.7 Índice de área foliar e área foliar específica .............................................. 32

3.8 Fitomassa seca da parte aérea, partição e produtividade de grãos ................ 33

3.9 Análise de crescimento quantitativo ............................................................ 34

3.10 Eficiência do uso da radiação ...................................................................... 34

3.11 Coeficiente de extinção da luz .............................................................. 34

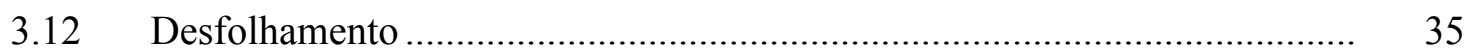

3.13 Coleta e análise dos dados meteorológicos............................................... 35

$4 \quad$ RESULTADOS E DISCUSSÃO ….......................................................... 37

4.1 Índice de área foliar ........................................................................ 37



4.3 Fitomassa seca da parte aérea de plantas, partição de fitomassa seca e produtividade de grãos................................................................................... $\quad 50$

4.4 Assimilação máxima de $\mathrm{CO}_{2}$, respiração e eficiência quântica ..................... 61

4.5 Eficiência de uso da radiação......................................................................... 66

4.6 Coeficiente de extinção da luz .................................................................. 71



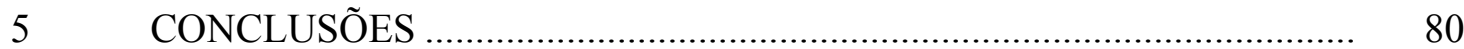

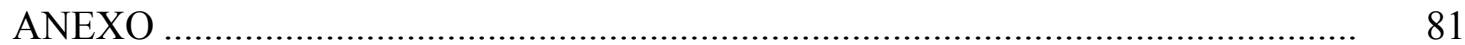

REFERÊNCIAS BIBLIOGRÁFICAS _............................................................ 87 


\section{LISTA DE SÍMBOLOS}

A $\quad$ g.m $\mathrm{m}^{-2} \cdot \mathrm{h}^{-1} \quad$ Taxa de assimilação bruta de $\mathrm{CO}_{2}$

$\varepsilon \quad \mathrm{g} \mathrm{CO}_{2} \cdot \mathrm{MJ}^{-1} \quad$ Eficiência quântica

AFE $\quad \mathrm{cm}^{2} \cdot \mathrm{g}^{-1} \quad$ Área foliar específica

$\mathrm{A}_{\mathrm{m}} \quad \mathrm{g} \cdot \mathrm{m}^{-2} \cdot \mathrm{h}^{-1} \quad$ Taxa de assimilação bruta máxima de $\mathrm{CO}_{2}$

$\mathrm{CO}_{2} \quad$ Dióxido de carbono

DMS Diferença mínima significativa

FSa $\quad$ kg.ha ${ }^{-1} \quad$ Fitomassa seca de parte aérea

FSc $\quad$ kg.ha ${ }^{-1} \quad$ Fitomassa seca de colmo

FSe $\quad$ kg.ha ${ }^{-1} \quad$ Fitomassa seca de espiga

$\mathrm{FSe} / \mathrm{FSa} \quad$ Relação fitomassa seca de espiga/fitomassa seca parte aérea

FSf kg.ha ${ }^{-1} \quad$ Fitomassa seca de folha

FSfs $\quad$ kg.ha ${ }^{-1} \quad$ Fitomassa seca de folha seca

FSge $\quad$ g.espiga $^{-1} \quad$ Fitomassa seca de grãos da espiga por espiga

FSpe $\quad$ g.espiga $^{-1} \quad$ Fitomassa seca de palha da espiga por espiga

FSse $\quad$ g.espiga $^{-1} \quad$ Fitomassa seca de sabugo da espiga por espiga

IAF $\quad \mathrm{m}^{2} \cdot \mathrm{m}^{-2} \quad$ Índice de área foliar

$\mathrm{k}$

Coeficiente de extinção da luz

$\mathrm{N} \quad$ nitrogênio

PAR MJ.m ${ }^{-2} \cdot$ dia $^{-1}$ Radiação fotossinteticamente ativa

PARi MJ.m ${ }^{-2} \cdot \operatorname{dia}^{-1}$ Radiação fotossintéticamente ativa interceptada

Pgr kg.ha ${ }^{-1} \quad$ Produtividade de grãos com $13 \%$ de umidade

PPFD $\quad \mu \mathrm{mol} . \mathrm{m}^{-2} . \mathrm{s}^{-1} \quad$ Densidade de fluxo de fótons fotossintético

RUE $\quad \mathrm{g} \mathrm{FSa} . \mathrm{MJ}^{-1}$ Eficiência de utilização (uso) da radiação

TAL $\quad$ g.m $\mathrm{m}^{-2} \cdot \mathrm{dia}^{-1} \quad$ Taxa assimilatória líquida 
TCC kg.ha ${ }^{-1} \cdot$ dia $^{-1} \quad$ Taxa de crescimento de cultura

TCR kg.kg ${ }^{-1} \cdot$ dia $^{-1}$ Taxa de crescimento de relativo 


\section{LISTA DE FIGURAS}

Página

1 Vista geral do experimento no campo

2 Disposição dos tubos solarímetros sob a cultura ............................................... 36

3 Estação meteorológica automática e datalogger ............................................ 36

4 Índice de área foliar de 3 híbridos de milho da emergência ao ponto de maturidade fisiológico

5 Área foliar específica de três híbridos de milho da emergência ao estádio de grão farináceo duro

6 Fitomassa seca de parte aérea (total), Fitomassa seca de colmo, fitomassa seca de folhas, fitomassa seca de folha seca, fitomassa seca de espiga, taxa de crescimento de cultura (TCC) e taxa assimilatória líquida (TAL) de três híbridos de milho, da emergência ao estado de grão farináceo duro

7 Radiação total diária (MJ.m ${ }^{-2} \cdot$ dia $^{-1}$ ) de Piracicaba-SP de 29 de setembro de 2003 (emergência) a 02 de fevereiro de 2004 (ponto de maturidade fisiológico). (Os meses são mostrados no primeiro dia de cada mês)

8 Relação entre a acumulação de fitomassa seca da parte aérea e PAR interceptado acumulado dos híbridos BRS 1010, BRS 3003 e BRS 1001, da emergência ao estádio de grão pastoso

9 Variação da fração interceptada da radiação PAR ( ) e do IAF durante o ciclo dos híbridos BRS 1010, BRS 3003 e BRS 1001

10 Foto dos híbridos BRS 1010 (esquerda), BRS 3003 (centro) e BRS 1001 (direita) 
11 Produtividade relativa (\%) dos híbridos BRS 1010, BRS 3003 e BRS 1001, submetidos a tratamento de desfolha dos estratos, superior, médio e inferior após o período da antese

12 Foto das espigas dos híbridos BRS 1010, BRS 3003 e BRS 1001 obtidas de plantas que sofreram desfolhamento na época da polinização. (A) terço superior, (B) terço médio, $(\mathrm{C})$ terço inferior e (D) controle. 


\section{LISTA DE TABELAS}

Página

1 Teste de Tukey para médias de IAF $\left(\mathrm{m}^{2} \cdot \mathrm{m}^{-2}\right)$ de três híbridos de milho com diferentes arquiteturas de parte aérea. Estádio de 4 folhas - 21 DAE

2 Teste de Tukey para médias de IAF $\left(\mathrm{m}^{2} \cdot \mathrm{m}^{-2}\right)$ e espessura de estratos $(\mathrm{cm})$ do dossel vertical de três híbridos de milho com diferentes arquiteturas de parte aérea. (A) estrato médio superior e (B) estrato médio inferior. Estádio de 8 folhas -34 DAE

3 Teste de Tukey para médias de IAF $\left(\mathrm{m}^{2} \cdot \mathrm{m}^{-2}\right)$ e espessura de estratos $(\mathrm{cm})$ do dossel vertical de três híbridos de milho com diferentes arquiteturas de parte aérea: (A) estrato terço superior; (B) estrato terço médio; e (C) estrato terço inferior. Estádio de 12 folhas - 49 DAE

4 Teste de Tukey para médias de IAF $\left(\mathrm{m}^{2} \cdot \mathrm{m}^{-2}\right)$ e espessura de estratos $(\mathrm{cm})$ do dossel vertical de três híbridos de milho com diferentes arquiteturas de parte aérea: (A) estrato terço superior; (B) estrato terço médio; e (C) estrato terço inferior. Estádio de florescimento - 64 DAE

5 Teste de Tukey para médias de IAF $\left(\mathrm{m}^{2} \cdot \mathrm{m}^{-2}\right)$ e espessura de estratos $(\mathrm{cm})$ do dossel vertical de três híbridos de milho com diferentes arquiteturas de parte aérea: (A) estrato terço superior; (B) estrato terço médio; e (C) estrato terço inferior. Estádio de grão leitoso - $80 \mathrm{DAE}$

6 Teste de Tukey para médias de IAF $\left(\mathrm{m}^{2} \cdot \mathrm{m}^{-2}\right)$ e espessura de estratos $(\mathrm{cm})$ do dossel vertical de três híbridos de milho com diferentes arquiteturas de parte aérea: (A) estrato terço superior; (B) estrato terço médio; e (C) estrato terço inferior. Estádio de grão pastoso - $100 \mathrm{DAE}$ 
7 Teste de Tukey para médias de IAF $\left(\mathrm{m}^{2} \cdot \mathrm{m}^{-2}\right)$ e espessura de estrato $(\mathrm{cm})$ do dossel vertical de três híbridos de milho com diferentes arquiteturas de parte aérea: (A) estrato terço superior. Estádio de grão farináceo duro - 114 DAE .....

8 Teste de Tukey para médias de AFE $\left(\mathrm{cm}^{2} \cdot \mathrm{g}^{-1}\right)$ de folhas do dossel vertical estratificado de três híbridos de milho com diferentes arquiteturas de parte aérea, do estádio de 4 folhas ao grão farináceo duro. (A) estrato terço superior; (B) estrato terço médio; e (C) estrato terço inferior ..

9 Teste de Tukey para médias de AFE $\left(\mathrm{cm}^{2} \cdot \mathrm{g}^{-1}\right)$ de folhas do dossel vertical estratificado de três híbridos de milho com diferentes arquiteturas de parte aérea, do estádio de 4 folhas ao grão farináceo duro. (A) estrato terço superior; (B) estrato terço médio; e (C) estrato terço inferior

10 Teste de Tukey para médias de FSc, FSf, e FSa $\left(\mathrm{kg} \cdot \mathrm{ha}^{-1}\right)$ de três híbridos de milho com diferentes arquiteturas de parte aérea. Estádio de 4 folhas -21 DAE

11 Teste de Tukey para médias de FSc, FSf, e FSa $\left(\mathrm{kg} \cdot \mathrm{ha}^{-1}\right)$ de três híbridos de milho com diferentes arquiteturas de parte aérea. Estádio de 8 folhas -34 DAE

12 Teste de Tukey para médias de FSc, FSf, e FSa $\left(\mathrm{kg} \cdot \mathrm{ha}^{-1}\right)$ de três híbridos de milho com diferentes arquiteturas de parte aérea. Estádio de 12 folhas - (49 DAE)

13 Teste de Tukey para médias de FSc, FSf, e FSa $\left(\mathrm{kg} \cdot \mathrm{ha}^{-1}\right)$ de três híbridos de milho com diferentes arquiteturas de parte aérea. Estádio de florescimento 64 DAE.

14 Teste de Tukey para médias de FSc, FSf, FSfs, FSe, FSa $\left(\mathrm{kg} \cdot \mathrm{ha}^{-1}\right)$ e relação FSe/FSa de três híbridos de milho com diferentes arquiteturas de parte aérea. Estádio de grão leitoso - 80 DAE

15 Teste de Tukey para médias de FSc, FSf, FSfs, FSe, FSa em kg.ha ${ }^{-1}$ e relação FSe/FSa de três híbridos de milho com diferentes arquiteturas de parte aérea. Estádio de grão pastoso - $100 \mathrm{DAE}$ 
16 Teste de Tukey para médias de FSc, FSf, FSfs, FSe, FSa $\left(\mathrm{kg} \cdot \mathrm{ha}^{-1}\right)$ e relação FSe/FSa de três híbridos de milho com diferentes arquiteturas de parte aérea. Estádio de grão farináceo duro - 114 DAE.

17 Teste-T para médias de Pgr $\left(\mathrm{kg} \cdot \mathrm{ha}^{-1}\right)$ de três híbridos de milho com diferentes arquiteturas de parte aérea. Estádio de ponto de maturidade fisiológico - 127 DAE

18 Médias de Am $\left(\mathrm{g} \cdot \mathrm{m}^{-2} \cdot \mathrm{h}^{-1}\right.$ de $\left.\mathrm{CO}_{2}\right)$, respiração foliar de escuro $\left(\mathrm{g} \cdot \mathrm{m}^{-2} \cdot \mathrm{h}^{-1}\right.$ de $\mathrm{CO} 2)$ e $\varepsilon$ (g.MJ-1 de $\mathrm{CO}_{2}$ ) de três híbridos de milho com diferentes arquiteturas de parte aérea. Estádio de 4 folhas - 21 DAE

19 Médias de Am $\left(\mathrm{g} \cdot \mathrm{m}^{-2} \cdot \mathrm{h}^{-1}\right.$ de CO2), respiração de escuro foliar $\left(\mathrm{g} \cdot \mathrm{m}^{-2} \cdot \mathrm{h}^{-1}\right.$ de $\left.\mathrm{CO}_{2}\right)$ e $\varepsilon\left(\mathrm{g} \cdot \mathrm{MJ}^{-1}\right.$ de $\left.\mathrm{CO}_{2}\right)$ no estrato médio superior $(\mathrm{A})$ e médio inferior (B) de três híbridos de milho com diferentes arquiteturas de parte aérea.com diferentes ângulos de inserção foliar. Estádio de 8 folhas - 34 DAE

20 Médias de $\mathrm{Am}\left(\mathrm{g} \cdot \mathrm{m}^{-2} \cdot \mathrm{h}^{-1}\right.$ de $\left.\mathrm{CO}_{2}\right)$, respiração de escuro foliar $\left(\mathrm{g} \cdot \mathrm{m}^{-2} \cdot \mathrm{h}^{-1}\right.$ de $\mathrm{CO} 2)$ e $\varepsilon\left(\mathrm{g} \cdot \mathrm{MJ}^{-1}\right.$ de $\left.\mathrm{CO}_{2}\right)$ no estrato terço superior $(\mathrm{A})$, terço médio (B) e terço inferior (C) de três híbridos de milho com diferentes arquiteturas de parte aérea. Estádio de 12 folhas - 49 DAE

21 Médias de Am $\left(\mathrm{g} \cdot \mathrm{m}^{-2} \cdot \mathrm{h}^{-1}\right.$ de $\left.\mathrm{CO}_{2}\right)$, respiração de escuro foliar $\left(\mathrm{g} \cdot \mathrm{m}^{-2} \cdot \mathrm{h}^{-1}\right.$ de $\mathrm{CO} 2)$ e $\varepsilon\left(\mathrm{g}^{\mathrm{M}} \mathrm{MJ}^{-1}\right.$ de $\left.\mathrm{CO}_{2}\right)$ no estrato terço superior (A), terço médio (B) e terço inferior (C) de três híbridos de milho com diferentes arquiteturas de parte aérea. Estádio de grão leitoso - $80 \mathrm{DAE}$

22 Eficiência de uso da radiação $\left(\right.$ g. $\left.\mathrm{MJ}^{-1}\right)$ de três híbridos de milho com diferentes arquiteturas de parte aérea referente a 6 intervalos entre estádios de fase fenológica.

23 Eficiência de uso da radiação $\left(\mathrm{g} \cdot \mathrm{MJ}^{-1}\right)$ de três híbridos de milho com diferentes arquiteturas de parte aérea, nas fases vegetativa e reprodutiva e da emergência a grão pastoso

24 Coeficiente de extinção da luz de três híbridos de milho com diferentes arquiteturas de parte aérea calculados em cinco estádios de desenvolvimento e a sua média 
25 Variação horária dos valores médios do coeficiente de extinção (k) da luz de três híbridos de milho, com diferentes arquiteturas de parte aérea, calculados em cinco diferentes estádios de desenvolvimento

26 Teste de Tukey para comparação de médias de fitomassa de grãos da espiga (g.espiga $^{-1}$ ) entre três híbridos (colunas) e dentro de cada híbrido de milho (linha), submetido ao desfolhamento dos terços superior (A), terço médio (B), terço inferior (C) e controle sem desfolhamento (D) do dossel vertical após a antese

27 Teste de Tukey para comparação de médias de fitomassa de grãos da espiga $\left(\right.$ g.espiga $^{-1}$ ) para conjunto de três híbridos de milho submetido ao desfolhamento do terço superior (A), terço médio (B), terço inferior (C) e controle sem desfolhamento (D) do dossel vertical após a antese........................ 79

28 Temperatura, radiação solar e precipitação 


\title{
DESEMPENHO FISIOLÓGICO DA CULTURA DE MILHO COM PLANTAS DE ARQUITETURA CONTRASTANTE: PARÂMETROS PARA MODELOS DE CRESCIMENTO
}

\author{
Autor: MARCELO RIBEIRO ROMANO \\ Orientador: Prof. Dr. DURVAL DOURADO NETO
}

\section{RESUMO}

A taxa de assimilação de dióxido de carbono por uma cultura é função da radiação fotossinteticamente ativa interceptada, a qual está intimamente relacionada com a arquitetura da parte aérea da cultura. O melhoramento genético de milho tem caminhado para a seleção de plantas com arquitetura de parte aérea mais ereta. Estudar a interceptação da radiação e suas consequências na produtividade de três híbridos de milho contrastantes em arquitetura de parte aérea foi o objetivo desta pesquisa. Para tanto, um experimento de campo sob condição irrigada foi conduzido na Escola Superior de Agricultura "Luiz de Queiroz", Universidade de São Paulo, em Piracicaba, Estado de São Paulo, Brasil, durante os anos de 2003 e 2004. De acordo com os resultados obtidos, nas condições do experimento, pode-se concluir que: (i) a arquitetura de parte aérea de milho afeta a interceptação de radiação solar na população de 66.000 plantas.ha $^{-1}$; (ii) a taxa de assimilação de dióxido de carbono máxima da folha recém madura varia com o estádio de desenvolvimento fenológico de forma crescente da emergência ao estádio de doze folhas; (iii) para uma determinada folha, a taxa de assimilação de dióxido de carbono máxima é sempre constante da emergência ao estádio de doze folhas; (iv) a área foliar específica diminui com a evolução do ciclo da cultura; (v) a ordem de grandeza da eficiência do uso da radiação pela cultura de milho é $3,9 \mathrm{~g} \cdot \mathrm{MJ}^{-1}$; (vi) a maior 
produtividade do genótipo de arquitetura foliar ereta se deve à maior interceptação de radiação por unidade de área foliar, com conseqüente maior taxa assimilatória líquida; (vii) genótipo de arquitetura foliar ereta apresenta menor queda de produtividade de grãos quando o terço superior do dossel é desfolhado; e (viii) o coeficiente de extinção deve ser determinado especificamente para cada genótipo, levando em consideração a variação temporal (escala horária) durante o dia. 


\title{
PHYSIOLOGICAL PERFORMANCE OF THE MAIZE CROP WITH DIFFERENT PLANTS ARCHITECTURE: PARAMETERS FOR GROWTH MODELS
}

\author{
Author: MARCELO RIBEIRO ROMANO \\ Adviser: Prof. Dr. DURVAL DOURADO NETO

\section{SUMMARY} \\ Carbon dioxide assimilation rate varies with active photosynthetic radiation \\ interception. Crop shoot architecture defines radiation interception. Maize breeding had \\ lead to erect shoot architecture plants selection. The objective of this research was to \\ study the radiation interception, and its effects, on three hybrids maize contrasting shoot \\ architecture. Therefore, an irrigated field experiment was carried out in the Escola \\ Superior de Agricultura "Luiz de Queiroz”, Universidade de São Paulo, Piracicaba, State \\ of São Paulo, Brazil, during the summer growing seasons of 2003 and 2004. According \\ to the results, in the experiment conditions, it is possible to conclude that: (i) the maize \\ shoot architecture affects the solar radiation interception when plants density was 66,000 \\ plants.ha $^{-1}$; (ii) The maximum carbon dioxide assimilation rate of a mature leaf varies \\ with the phenological development (increasing from the emergence point to when the \\ plants have 12 leaves); (iii) for a certain leaf, the maximum carbon dioxide assimilation \\ is constant (from the emergence point to when the plants have 12 leaves); (iv) specific \\ leaf area decreases along the crop development; (v) maize radiation use efficiency mean \\ is $3,9 \mathrm{~g} \cdot \mathrm{MJ}^{-1}$; (vi) the higher yield, presented by the genotype with erect leaves, is due to \\ a higher radiation interception by leaf area unit, which leads to a higher assimilation rate \\ net; (vii) the genotype with erect leaves architecture presents smaller grain yield drop
}


when the upper third canopy is taken out; and (viii) light extinction coefficient must be determinate for each genotype, when time variation is considered (hour scale) along the day. 


\section{INTRODUÇÃO}

O melhoramento de milho nos últimos anos tem levado a seleção de genótipos mais produtivos e com ciclo melhor ajustado ao período mais favorável para o crescimento e desenvolvimento. A arquitetura da parte aérea da planta de milho é uma característica que está sendo modificada indiretamente por essa seleção. Genótipos de milho, produtivos e com ciclo de vida mais curto, freqüentemente estão associados à arquitetura da parte aérea caracterizada por folhas mais eretas. Tal característica, aliada com o menor porte, tem permitido aumento de população de plantas por área cultivada, muitas vezes ultrapassando 80.000 plantas.ha ${ }^{-1}$.

Todos os organismos vivos interagem com o seu ambiente físico através dos processos de troca de energia. Para as plantas, esses processos de troca de energia são decisivos para o estabelecimento das temperaturas foliares, das taxas de ganho de carbono fotossintético e das taxas de perda de água. Como as plantas são sésseis, existem restrições na sua habilidade de alterar o ambiente e a energia ao seu redor. Então, mecanismos para modular as trocas de energia entre a folha e o ambiente são cruciais para a planta, na tentativa de se manter o potencial de crescimento e reprodução. O ângulo foliar e as características da superfície foliar são, em grande parte, responsáveis pela quantidade de radiação interceptada pela folha e pela fração dessa possível de ser absorvida, respectivamente. A interação entre o tamanho da folha, forma e o grau de abertura estomática interagem para estabelecer quanto da radiação absorvida pode virar re-emissão, convecção e calor latente de troca.

As características morfológicas de um dossel de cultura e a eficiência de processos fisiológicos, influenciando e sendo influenciadas pelos elementos do microclima (radiação, temperatura, vento e umidade), definem a quantidade de fotoassimilados que uma planta produz. A forma de consumo destes fotoassimilados é 
que distingue se uma espécie ou uma variedade apresenta características agronômicas superiores à outra.

Desde que a folha é o órgão onde ocorrem as maiores trocas de energia e gases entre o meio e a planta, conhecer a influência da sua disposição, orientação, tamanho, forma e propriedades óticas, sintetizadas na arquitetura do dossel, sobre o meio físico, e as conseqüências dessa interação nos processos que se desenvolvem desde a escala de célula até de cultura são fundamentais para se estabelecer manejos fitotécnicos baseados no conhecimento científico.

$\mathrm{O}$ cálculo da assimilação de $\mathrm{CO}_{2}$ pelo dossel fotossintético das culturas vegetais é a parte central da maioria dos modelos de simulação de crescimento e produção de culturas. Entre os fatores que controlam a taxa de assimilação de $\mathrm{CO}_{2}$ pelo dossel, a densidade de fluxo de fótons que atinge as folhas e a temperatura são os principais. A diferença entre a maioria dos modelos está no tratamento dada a penetração da radiação no dossel, um fenômeno intimamente relacionado com a arquitetura de parte aérea do dossel.

A arte de desenvolver modelos que simulam processos em sistemas retirados de um mundo real é uma ferramenta valorosa para o aprendizado de processos, desvendar lacunas do conhecimento, obter resposta rápida de alterações nas variáveis que compõem o processo e fazer previsões antecipadas com o objetivo de orientar agricultores e governos na tomada de decisões. O desenvolvimento de modelos baseados em índices obtidos por equipe multidisciplinar de modeladores, através de experimentação agronômica clássica, em condições locais e com variabilidade genética de uso corrente naqueles ambientes, traz mais confiança no uso do modelo desenvolvido, superando as calibrações de modelos importados em que a maioria dos índices não é passível de modificações.

O presente trabalho teve como objetivos: (i) obter índices biométricos e fisiológicos de híbridos tropicais de milho (BRS 1010, BRS 3003 e BRS 1001) contrastantes em arquitetura de parte aérea visando servirem de parâmetros para modelos de estimativa de crescimento e produtividade, (ii) avaliar a influência da arquitetura no valor do coeficiente de extinção (k); (iii) determinar o valor da eficiência 
do uso da radiação; (iv) verificar a influência do desfolhamento de diferentes estratos do dossel vertical de híbridos contrastantes em arquitetura de parte aérea no rendimento de grãos. 


\section{REVISÃO DE LITERATURA}

\subsection{A cultura de milho}

\subsubsection{Importância econômica e social}

O milho (Zea mays L.) é o segundo cereal em importância no mundo, após o trigo e seguido pelo arroz (Lisboa et al., 1999). Algumas vantagens conferidas à cultura do milho justificam a sua ampla distribuição, tais como: (i) composição e valor nutritivo; (ii) alta produção por unidade de trabalho e unidade de área; (iii) fonte de nutrição de fácil transporte; (iv) pequenas perdas de grãos causadas por pássaros e chuvas; (v) período longo de colheita; e (vi) permite o armazenamento (Jones, 1985).

Devido a sua grande diversidade de aplicações, tanto na alimentação humana quanto na alimentação animal, a cultura de milho apresenta relevante importância social e econômica. Além da geração de empregos no setor primário, o milho é matéria-prima indispensável para impulsionar diversos complexos agroindustriais (Fancelli \& Dourado Neto, 2000).

O Brasil é o terceiro maior produtor mundial, sendo superado apenas pelos Estados Unidos e pela China. A área semeada no Brasil varia em torno de 13 milhões de hectares, com uma produção aproximada de 41,5 milhões de toneladas, conferindo uma produtividade de 3 t.ha $^{-1}$. A "safrinha" participa ocupando uma área em torno de 3 milhões de hectares e respondo com 13,5\% da produção nacional. Os maiores Estados produtores são: Paraná (29,4\%); Rio Grande do Sul (13,5\%) e Minas Gerais (10,8\%) (FNP, 2002).

$\mathrm{Na}$ última década, a cultura no Brasil obteve um expressivo ganho de produtividade, fruto das pesquisas no desenvolvimento de novos genótipos e de práticas de manejo da cultura. A Empresa Brasileira de Pesquisa Agropecuária (Embrapa), 
através do Centro de Milho e Sorgo, coordena uma das mais importantes pesquisas de seleção de novos genótipos de milho para as diversas regiões do Brasil, são os denominados Ensaios Nacionais e Regionais de Milho. No entanto, a produtividade brasileira de milho está ainda longe das produtividades médias de 10 t.ha $^{-1}$ obtidas por países como os Estados Unidos e França.

\subsubsection{Fenologia}

O milho é uma planta de ciclo vegetativo variado, evidenciando desde genótipos extremamente precoces, cuja polinização pode ocorrer 30 dias após a emergência, até mesmo aqueles cujo ciclo vital pode alcançar 300 dias. Contudo, em nossas condições, a cultura do milho apresenta ciclo variável entre 110 e 180 dias, em função da caracterização dos genótipos (superprecoce, precoce, normal), período esse compreendido entre a semeadura e a colheita (Fancelli \& Dourado Neto, 2000).

De acordo com Fancelli \& Dourado Neto (2000), o ciclo da cultura compreende

cinco etapas de desenvolvimento: (i) germinação e emergência: ocorre entre a semeadura e o aparecimento da plântula, cujo período varia entre 4 e 12 dias, em função da temperatura e umidade do solo; (ii) crescimento vegetativo: iniciado a partir da emissão da segunda folha, até o início do florescimento, cuja extensão varia em função do genótipo e de fatores climáticos, caracterizando e classificando diferentes genótipos quanto à duração do ciclo; (iii) florescimento: estabelecido entre o início da polinização e o início da frutificação; (iv) frutificação: período compreendido entre a fecundação e o enchimento completo dos grãos, cuja duração varia entre 40 e 60 dias; (v) maturidade: período compreendido entre o final da frutificação e o aparecimento da "camada preta" no ponto de inserção dos grãos com o sabugo. A formação da "camada preta" representa o rompimento do elo de ligação entre a planta-mãe e fruto, caracterizando o momento ideal para a colheita, em função da máxima produção concentrada. Porém, a alta umidade dos grãos nesse momento ( $30 \%$ a $38 \%$ ), constitui-se num impedimento natural às operações mecânicas inerentes a um processo de colheita eficiente, o que torna-se possível quando a umidade dos grãos encontra-se entre $18 \%$ e $25 \%$, procedendo-se à 
secagem artificial até $13 \%$ de umidade, permitindo seu armazenamento seguro (Fancelli \& Dourado Neto, 2000).

Entretanto, para maior facilidade de manejo e estudo, bem como objetivando a possibilidade do estabelecimento de correlações entre elementos fisiológicos, climatológicos, fitogenéticos, entomológicos, fitopatológicos, fitotécnicos, com o desempenho da planta, o ciclo da cultura do milho foi dividido em 11 estágios distintos de desenvolvimento, segundo Fancelli (1986), citado por Fancelli \& Dourado Neto (2000) (i) estádio 0 (da semeadura à emergência); (ii) estádio 1 (planta com quatro folhas totalmente desdobradas); (iii) estádio 2 (planta com oito folhas); (iv) estádio 3 (plantas com doze folhas); (v) estádio 4 (emissão do pendão); (vi) estádio 5 (florescimento e polinização); (vii) estádio 6 (grãos leitosos); (viii) estádio 7 (grãos pastosos); (ix) estádio 8 (início da formação de "dentes" que é a concavidade na parte superior do grão); (x) estádio 9 (grãos “duros”); e (x) estádio 10 (grãos maduros fisiologicamente).

Porém, deve-se ressaltar que os estádios de crescimento e desenvolvimento anteriores ao aparecimento das espigas são identificados, mediante a avaliação do número de folhas plenamente expandidas ou desdobradas. Assim, a folha do milho pode ser considerada desdobrada quando a mesma apresenta a linha de união lâmina-bainha (“colar") facilmente visível. Para os estádios posteriores à emissão da espiga, a identificação deverá ser efetuada com base no desenvolvimento e consistência dos grãos (Kiniry \& Bonhomme, 1991).

\subsubsection{Temperatura}

A produtividade de milho depende do número de grãos por unidade de área e da quantidade de fotoassimilados disponíveis para esses grãos. É variável entre os diferentes híbridos ou cultivares e é influenciada por fatores de ambiente que predominam no período em torno da fertilização. Nesse período crítico, deficiência hídrica, deficiência nutricional, elevado número de dias nublados (baixa disponibilidade de radiação solar), sombreamento devido as altas populações podem provocar 
abortamento de grãos, mesmo após fertilizados, reduzindo o número de grãos (Rodrigues \& Didonet, 2001).

A produtividade de uma cultura de milho depende diretamente da relação intrínseca estabelecida entre a planta e o ambiente físico em que se encontra, com ênfase para a temperatura, luz, ventos e disponibilidade hídrica, o que determina a adaptação de diferentes genótipos para diferentes ambientes, em função do manejo adotado (Palhares, 2003).

Para Fancelli \& Dourado Neto (2000), a fotossíntese, respiração e transpiração são processos fisiológicos da planta de milho que resultam diretamente da energia disponível no ambiente, comumente chamada de calor.

De acordo com Shaw (1977), as maiores produções de milho ocorrem onde as temperaturas nos meses mais quentes oscilam de $21^{\circ} \mathrm{C}$ a $27^{\circ} \mathrm{C}$. Aparentemente, segundo o autor acima citado, não existe um limite máximo de temperatura para a produção de milho, no entanto, a produtividade tende a diminuir com o aumento da temperatura.

O conceito de temperatura ótima deve ser visto com cautela, pois esta temperatura varia com o estádio de desenvolvimento da planta, por exemplo, a temperatura ótima para germinação não é a mesma para a floração ou frutificação, podendo ainda ser diferente da temperatura ótima para o desenvolvimento vegetativo (Nunes, 1993).

Para o milho, o período compreendido entre 15 dias antes e 15 dias após o aparecimento da inflorescência masculina, o requerimento de um suprimento hídrico satisfatório aliado à temperatura adequada tornam tal períodos extremamente crítico. Daí, a razão pela qual a mencionada fase deve ser criteriosamente planejada, com o intuito de coincidir com período estacional que apresenta temperaturas favoráveis $\left(25^{\circ} \mathrm{C}\right.$ a $30^{\circ} \mathrm{C}$ ) e chuvas freqüentes (Frattini, 1975).

Dados experimentais relatam que a cada grau de temperatura média diária superior a $21,1^{\circ} \mathrm{C}$ nos primeiros 60 dias após a semeadura pode apressar o florescimento de dois a três dias (Fancelli \& Dourado Neto, 2000). 
A elevação da temperatura contribui para a redução da taxa fotossintética líquida em função do aumento da respiração, interferindo diretamente na produção (Fancelli \& Dourado Neto, 2000).

Temperaturas elevadas prevalecentes no período noturno (maiores que $24^{\circ} \mathrm{C}$ ) promovem um consumo energético elevado, em função do incremento da respiração celular, ocasionando menor saldo de fotoassimilados, com conseqüente queda na produtividade da cultura. Da mesma maneira, temperaturas acima de $32{ }^{\circ} \mathrm{C}$ reduzem, sensivelmente a germinação do grão de pólen, por ocasião de sua emissão (Fancelli \& Dourado Neto, 2000).

No desenvolvimento do milho, a duração do ciclo em dias tem demonstrado inconsistência. Isso se deve ao fato de que a duração de subperíodos e dos ciclos da planta estão associados às variações das condições ambientais, e não ao número de dias dos meses. De forma generalizada, a temperatura apresenta-se como o elemento climático mais importante para predizer os eventos fenológicos da cultura (Gadioli, 1999). Tendo em vista o sucesso na predição de datas de ocorrência dos estádios de desenvolvimento da cultura do milho, os modeladores têm afirmado que o conceito unidade térmica é universalmente aplicável (Lima, 1995; Bergonci \& Bergamaschi, 2002).

Segundo Villa Nova et al. (1972), a quantidade de energia exigida por uma cultura tem sido expressa em graus-dia, ou unidades térmicas de desenvolvimento, exigência térmica, exigência calórica, unidade de calor. Graus-dia é definido como a diferença entre a temperatura média diária e a temperatura base inferior de determinada espécie. A base teórica para essa técnica é que, dos processos envolvidos no desenvolvimento e crescimento da cultura, todos são sensíveis à temperatura do ar, cabendo enfatizar que a resposta das plantas à temperatura do ar obedece a limites (inferior e superior) e é extensiva ao desenvolvimento total da cultura. Segundo Wislie (1962), a temperatura basal inferior de crescimento do milho é de $10^{\circ} \mathrm{C}$, a ótima varia de 28 a $35^{\circ} \mathrm{C}$ e a temperatura basal superior é de aproximadamente $45^{\circ} \mathrm{C}$. Para Kiniry (1991), o limite inferior e superior para o desenvolvimento e crescimento da planta de 
milho estão entre $8^{\circ} \mathrm{C}$ e $44^{\circ} \mathrm{C}$, respectivamente, sendo que o desenvolvimento e crescimento máximo ocorre entre $26^{\circ} \mathrm{C}$ e $34^{\circ} \mathrm{C}$.

A temperatura é um dos principais fatores de ambiente que pode afetar o rendimento de grãos de milho, através de seu efeito na duração e na taxa de acúmulo de massa seca pelos grãos, refletindo diretamente no rendimento final de grãos. Normalmente, o aumento da temperatura provoca aumento na taxa de crescimento e diminuição na duração do período em que os grãos permanecem acumulando massa seca (Muchow, 1990), tendo reflexos no peso final de grãos.

O aumento da temperatura contribui para a redução da taxa fotossintética líquida em função do aumento da respiração, interferindo diretamente na produção. Assim, temperaturas elevadas prevalecentes no período noturno (superior a $24^{\circ} \mathrm{C}$ ) promovem um consumo energético demasiado, em função do incremento da respiração celular, ocasionando menor saldo de fotoassimilados, com conseqüente queda na produtividade da cultura (Dourado Neto, 1999).

\subsubsection{Radiação}

A quantidade de energia solar atingindo uma superfície na terra é dependente da orientação da superfície relativa a posição do sol, e da transmissividade atmosférica (Forseth \& Norman, 1995). A posição do sol no céu é determinada pela latitude, dia do ano e horas do dia. A transmissividade atmosférica é uma função da altitude, nebulosidade e quantidade de partículas (poluentes, poeira e vapor d'água) na ar (Forseth \& Norman, 1995; Alfonsi, 1991).

A distribuição difusa representa a parte da radiação que interage com gases e nuvens presentes na atmosfera (Goudriaan \& Laar, 1994). O balanço de energia radiante, também denominada de radiação líquida, vem a ser o saldo de radiação sobre uma superfície (Ometo, 1981).

Algumas considerações sobre a importância do balanço de energia e a radiação líquida na determinação do fluxo de vapor d'água na atmosfera são feitas por Villanueva (1987) e diversos foram os estudos desenvolvidos por pesquisadores voltados ao monitoramento do saldo de radiação, bem como aos aspectos de sua partição nos 
variados sistemas agrícolas. A radiação solar é praticamente a única fonte de energia para os processos fisiológicos e bioquímicos que ocorrem nos vegetais. Sendo assim, a produção final de matéria seca de uma planta depende, em última instância, da eficiência com que as folhas convertem energia radiante em energia química, por meio da fotossíntese (Assis \& Mendez, 1989).

O cálculo da energia livre entrando em um sistema planta-ambiente é necessário para se estimar o potencial produtivo de culturas ou comunidade de plantas. A fotossíntese é o processo básico de transformação de energia nesse complexo sistema, e os modelos correntes de utilização de radiação pelas plantas são quase sempre baseados na irradiância de PAR (radiação fotossinteticamente ativa), ao invés da radiação solar total. A amplitude do PAR é determinada de acordo com a banda do espectro de absorção dos pigmentos das plantas. Os comprimentos de onda da radiação entre 400 e 750nm são normalmente considerados como a faixa do PAR.

Jong et al. (1982) mostraram que a produção de milho no Hawaii foi linearmente relacionada à radiação incidente e respondeu a 78,5\% da variação da produtividade. No entanto, diferenças no desenvolvimento de dossel entre culturas e climas podem confundir comparações de eficiência baseada apenas na radiação incidente.

A eficiência do uso da radiação de cultura (RUE, g.MJ ${ }^{-1}$ ) é uma variável derivada da relação da massa de matéria seca acumulada da cultura $\left(\mathrm{FSa}, \mathrm{g} \cdot \mathrm{m}^{-2}\right)$ e da radiação interceptada pelo dossel vegetal (PARi, MJ.m ${ }^{-2}$ ) num intervalo de tempo. RUE é uma medida independente que pode ser usada para descrever o desempenho de culturas e destacar limitações na produtividade. Monteith (1977) e Biscoe \& Gallagher (1977) estabeleceram que a RUE é relacionada quase que linearmente com a radiação fotossinteticamente ativa absorvida (PARa). Para efeito de cálculo, o PAR representa 40 a $50 \%$ do total da radiação solar direta coletada pelos solarímetros, ou seja, é a radiação possível de ser interceptada pelas folhas. Essa estimativa já inclui a presença da radiação difusa, rica em PAR. De acordo com o conteúdo de clorofila nas folhas, a radiação absorvida pelas plantas pode representar de 80 a $90 \%$ da radiação interceptada.

Teoricamente, RUE depende da taxa de assimilação de $\mathrm{CO}_{2}$ pelas folhas. $\mathrm{O}$ incremento na RUE está diretamente ligado ao incremento da taxa de fotossíntese foliar. 
Segundo Sands (1996), a RUE é alterada substancialmente pela fotossíntese máxima e a eficiência quântica e pouco alterada pelas diferenças de altitude, latitude, época do ano, ângulo foliar e índice de área foliar. Análises teóricas das potenciais fontes de variação entre locais são atribuídas à radiação solar e à fração de radiação difusa (Sinclair \& Muchow, 1999). Sands (1996) conclui que a temperatura pode influenciar RUE dependendo da resposta fotossintética à temperatura. Gosse et al. (1986) avaliaram diferentes espécies quanto a RUE e encontraram, em corroboração com análises teóricas, que espécies $\mathrm{C}_{4}$ apresentaram maiores valores de RUE que espécies $C_{3}$. Andrade et al. (1992; 1993), trabalhando com milho na região de BalcarceArgentina, verificaram um decréscimo linear de RUE em função da diminuição da temperatura média na faixa de 21 a $16{ }^{\circ} \mathrm{C}$. RUE máxima em milho ocorre durante o crescimento vegetativo, e há uma tendência para decréscimo de RUE durante o enchimento de grãos associado com a mobilização do nitrogênio foliar para o grão (Muchow \& Davis, 1988). Os valores médios para RUE para milho de acordo com diversos trabalhos de literatura situam-se entre 3,2 a 3,4g. $\mathrm{MJ}^{-1}$ de PAR interceptado para o período vegetativo e 2,6 a 3,4 g. $\mathrm{MJ}^{-1}$ de PAR interceptado para todo o ciclo da cultura (Sinclair \& Muchow, 1999). Kiniry, et al. (1988) analisando vários trabalhos na literatura do tema, consideram um valor médio de 3,5 g. $\mathrm{MJ}^{-1}$ de PAR interceptado, para a cultura de milho.

A influência da assimilação de $\mathrm{CO}_{2}$ (A) na RUE é resultado da ligação entre a taxa de assimilação de $\mathrm{CO}_{2}$ (A) e o conteúdo de N foliar. Segundo Evans (1989), o nitrogênio influencia o crescimento e desenvolvimento das culturas pelos seus efeitos na variação temporal da área foliar e na capacidade fotossintética. Sinclair \& Horie (1989) concluíram que a variação da taxa máxima de assimilação de $\mathrm{CO}_{2}\left(\mathrm{~A}_{\mathrm{m}}\right)$ foliar foi diretamente associada com as trocas no teor de nitrogênio por unidade de área foliar (SLN, gN.m ${ }^{-2}$ folha) e desenvolveram argumentos teóricos que indicavam que uma relação hiperbólica entre RUE e SLN deveria existir, com uma grande sensibilidade de RUE aos baixos níveis de SLN.

Muchow \& Sinclair (1994) estudaram a relação entre RUE e o teor de N foliar em milho e sorgo derivado de diferentes níveis de $\mathrm{N}$ proveniente de fertilizante e 
observaram que existe uma saturação na resposta de RUE pelo incremento do conteúdo de $\mathrm{N}$ foliar. Wright \& Hammer (1994) observaram em cultura de amendoim que RUE observado foi $32 \%$ maior que o valor teórico de RUE considerando uma distribuição homogênea de SLN no dossel, sugerindo com isso que exista uma distribuição não uniforme de SLN no dossel. O gradiente do conteúdo de $\mathrm{N}$ foliar no dossel de culturas pode resultar da idade do tecido foliar, luz, ou ambos fatores (Werger \& Hirose, 1991). Em algumas poáceas perenes, a distribuição de SLN é marcada por um decréscimo exponencial do topo para a base do dossel (Pons et al., 1989).

Aproximadamente $75 \%$ em plantas $C_{3}$ e $60 \%$ em plantas $C_{4}$ de todo o nitrogênio das folhas estão envolvidos no processo de fotossíntese (Evans, 1989) e têmse amplamente demonstrado que o conteúdo de nitrogênio foliar apresenta um efeito robusto no ganho potencial de carbono pelas folhas (Field, 1983; van Keulen et al., 1989). Entretanto a capacidade fotossintética do dossel não depende apenas de SLN, mas sim da interação de SLN, distribuição da área foliar no dossel e a radiação ambiente. Pereira, et al. (1981) observaram que o conteúdo de $\mathrm{N}$ nas partes vegetativas do milho reduziu gradualmente durante o crescimento reprodutivo em forma harmônica com o incremento de $\mathrm{N}$ na espiga, sendo que a quantidade de $\mathrm{N}$ remobilizado foi equivalente à quantidade total de $\mathrm{N}$ acumulado nos grãos.

\subsection{Arquitetura de parte aérea}

Segundo Rodrigues \& Didonet (2003), o número potencial de óvulos (grãos) por espiga é determinado quando as plantas atingem 10 a 12 folhas com o colar visível, muito antes do espigamento, momento em que se estabelece o número real de grãos por espiga. Nesse período, sob ausência de deficiência hídrica e nutricional, os principais fatores que condicionam o número de grãos são interceptação de radiação solar e temperatura do ar. Assim, para se obter o máximo número de grãos por unidade de área, em determinada densidade de plantas, é recomendável fazer com que o pendoamento ocorra nos dias mais longos do ano, de modo a coincidir a máxima área foliar de plantas com a maior disponibilidade de radiação solar. 
A produção média de grãos de milho por área aumentou drasticamente durante a segunda metade do último século (Duvick \& Cossman, 1999). Entre os vários fatores que contribuíram para esse aumento está a seleção de novos híbridos sob condições adensadas de semeadura. O aumento da tolerância de plantas de milho à intensa competição por luz, nutrientes e água, vem sendo obtido pela seleção de genótipos mais produtivos sob alta população de plantas e em ampla variedade de áreas (Sangoi \& Salvador, 1998). Conseqüentemente, a mudança da tolerância ao estresse por densidade de plantas é mais um resultado indireto que direto da seleção (Tollenaar \& Wu, 1999).

A densidade de plantas é considerada uma das mais importantes práticas culturais que determinam a produtividade de grãos pela cultura de milho. As características de perfilhamento pobre e ausência de ramificação fazem da planta de milho, a poácea mais sensível a variação da densidade de semeadura.

A densidade ótima de semeadura para a cultura depende da interação entre o genótipo e o ambiente. O sistema de produção adotado engloba as condições ambientais e de manejo (radiação, temperatura, nutrientes; água e controle fitossanitário) disponíveis para o desenvolvimento e crescimento da cultura. O genótipo deve expressar suas características morfológicas e fisiológicas no ambiente escolhido para maximizar a produtividade de grãos. A arquitetura foliar é a característica morfológica que mais influencia a resposta do genótipo à densidade de plantas. A arquitetura foliar de uma planta de milho é representada pela interação do número de folhas, ângulo foliar, área foliar, formato e distribuição ao longo do colmo. A importância da arquitetura foliar está relacionada com a maximização da interceptação da radiação solar pelo dossel, passo essencial para a obtenção da produtividade potencial (Sangoi et al., 2002).

Estrutura de dossel refere-se ao conteúdo e organização do material da planta acima do solo, incluindo o tamanho, formato e orientação de órgão da planta, como folha, colmos, ramos, flores e frutos (Norman \& Campbell, 1989). A estrutura do dossel vegetal determina o microambiente dinâmico que se forma ao redor das folhas, atuando na densidade e composição do fluxo radiante, temperatura do ar, temperatura do solo, pressão de vapor do ar, temperatura da folha, calor armazenado no solo, velocidade do vento, interceptação da precipitação e duração de folha verde (Nobel, 1991; Norman \& 
Campbell, 1989; Beadle et al., 1985; Ross, 1981). Portanto, a estrutura do dossel tem uma grande influência na troca de massa e energia entre a planta e o ambiente.

A obtenção da variedade I.R.8 de arroz com arquitetura de parte aérea ereta representa um das maiores contribuições da fisiologia de plantas para o aumento da produtividade de espécies cultivadas, segundo Nobel et al. (1995). Tal estrutura de dossel permite que mais luz atinja as folhas inferiores, aumentando a interceptação da luz pelo dossel, resultando em aumento de fotossíntese pela comunidade vegetal (Beadle, et al., 1985).

A maioria dos genótipos precoces e superprecoces cultivados no Brasil apresentam pequena estatura, menor número de folhas e folhas mais eretas. A produção das plantas, apresentando essas características, resulta em redução relativa dos custos de produção e manutenção (ex. água, nutrientes e assimilados) por planta (Loomis \& Connor, 1992). A menor quantidade de biomassa por planta permite se colocar mais indivíduos por área, que levando ao aumento do índice de área foliar (IAF). O incremento no IAF favorece uma interceptação mais efetiva da luz (Tollenaar et al., 1997). Segundo Sinclair (1998), o incremento da produção de matéria seca de uma cultura está associado ao aumento do nível de radiação interceptado pelo seu dossel. A mudança da arquitetura foliar também permitiu aos híbridos modernos manter elevadas taxas fotossintéticas de folhas mesmo em altas densidades, o que não se verifica nos híbridos clássicos (Dwyer et al., 1991). Tollenaar (1992) verificou que em híbridos modernos ocorre um aumento na eficiência do uso da radiação durante o período de enchimento de grãos, o que resultou em maiores produções de grãos por planta e maiores produtividades finais, quando comparado com híbridos clássicos.

O conhecimento da distribuição vertical da área foliar é essencial para se estimar a radiação interceptada pelo dossel de uma cultura (Sivakrumar \& Virmani, 1984). A estimativa acurada da radiação interceptada é importante para o uso em modelos que integram a fotossíntese no dossel.

Segundo Boedhram et al. (2001), o IAF de milho é distribuído simetricamente na vertical da emergência até a maturidade. Esses autores mostraram que a distribuição normal deu um excelente ajuste da curva $\left(r^{2}>0,94\right)$ que mensura a distribuição do IAF a 
cada intervalo de $0,10 \mathrm{~m}$ da altura, independente do $\mathrm{N}$ aplicado, umidade do solo, estádio de desenvolvimento da cultura, ou época.

O IAF e a distribuição de área foliar dentro de um dossel de milho são os principais fatores determinantes da interceptação total de luz, afetando a fotossíntese, transpiração e acúmulo de matéria seca (Pearce et al., 1967; Lieth \& Reynolds, 1984). A distribuição vertical da área foliar é determinada pelo tamanho de folha, ângulo foliar, e comprimento de internódio. A concepção de um tipo ótimo de planta visando a performance da taxa de fotossíntese, crescimento e produção de grãos foi introduzido por Donald (1968). Mock \& Pearce (1975) definiram um ideotipo de milho com um IAF superior a 4, compreende ainda uma distribuição baseada em folhas anguladas mais verticalmente para aquelas situadas acima da espiga, e mais horizontalmente para aquelas situadas abaixo da espiga, com o objetivo único de maximizar a interceptação de luz pelo dossel.

Uma outra consideração na determinação da distribuição ótima da área foliar para fotossíntese, crescimento e produção de grãos é a comparação de taxas de fotossíntese em diferentes níveis no dossel. As folhas abaixo da espiga são mais velhas e mais sombreadas que aquelas mais altas no dossel e apresentam menores taxas fotossintéticas ainda quando expostas a luz solar direta (Dwyer \& Stewart, 1986). Folhas nas vizinhanças da espiga apresentam uma maior taxa fotossintética no dossel e também são as que envelhecem mais lentamente, então, elas mantêm suas taxas máximas de fotossíntese por um período mais longo que outras folhas na planta (Thiagarajah et al., 1981). Maior penetração de luz até folhas da espiga podem, portanto, contribuir para maiores taxas de crescimento do milho, que é conseguido através de folhas orientadas mais verticalmente que horizontalmente (Loomis \& Williams, 1969).

De fato, a utilização otimizada da radiação para a fotossíntese geralmente ocorre quando a radiação incidente é distribuída tanto uniformemente quanto possível entre as folhas, porque a fração de folhas que são expostas aos níveis de radiação acima da saturação lumínica da fotossíntese ou abaixo do ponto de compensação luminoso é então minimizado (Turitzin \& Drake, 1981). Nobel et al. (1995) mencionam que quando o IAF excede o valor de 3, dosséis com folhas eretas próximo ao topo e folhas horizontais 
próximo da base tendem a apresentar maior produtividade quando comparado a dosséis de distribuição aleatória ou com inclinações uniformes de folha.

A presença de muitas camadas de folhas e a mudança no decorrer do dia da disponibilidade e direção do fluxo radiante dificulta a integração da fotossíntese no dossel para as diversas culturas. Assim, até mesmo descrições aproximadas da radiação interceptada dentro de estandes regulares de culturas em monocultivo envolvem cálculos baseados em muitas assunções simplificadas (Nobel et al., 1995).

Diante da dificuldade de se analisar a absorção da radiação cobrindo todos os fatores, Nobel (1995) recomenda uma simplificação baseada na lei de Beer. Assume-se que o decréscimo do fluxo radiante de cima para baixo dentro de um dossel é semelhante a absorção da luz por uma solução de clorofila ou outros pigmentos. Ocorre um decréscimo mais ou menos exponencial com a quantia de material foliar deparado.

O coeficiente de absorção foliar (k) também denominado de coeficiente de extinção da luz é o parâmetro adimensional da equação que integra a queda no fluxo da radiação dentro de um dossel. Ele representa a fração absorvida dos fótons incidentes por unidade de área foliar. O valor de $\mathrm{k}$ varia entre as espécies, poáceas de dossel com folhas mais eretas apresentam menores valores, ao redor de 0,4 , permitindo uma maior penetração de luz, já culturas como soja, girassol e batata apresentam valores para $\mathrm{k}$ próximos a 1,0, tais culturas apresentam altos teores de clorofila e folhas e um dossel com folhas predominantemente horizontais. Dosséis com o predomínio de folhas no plano horizontal são denominados planofilos e naqueles onde ocorre o predomínio de folhas no plano vertical são denominados erectofilos (Nobel et al., 1995).

\subsection{Efeitos do desfolhamento em milho}

O período crítico no ciclo vital do milho inicia-se, aproximadamente, com 2 semanas antes da antese e se prolonga por 2 a 3 semanas após a anteses. A ocorrência de estresse antes do florescimento pode causar retração no desenvolvimento da espiga, enquanto que anormalidades durante e após a polinização poderão resultar no abortamento e redução do número e peso de grãos (Daynard \& Duncan, 1969). 
Pinter \& Kalman (1979) avaliando o comportamento de 6 híbridos de milho, com características vegetativas diferentes, constataram que a redução da área foliar dos materiais em estudo, na época do florescimento feminino, resultou em redução de 70 a 90g.planta ${ }^{-1}$ de grãos, bem como foram evidenciadas consideráveis diferenças nas reações dos seis genótipos ao tratamento de desfolha.

Em experimento desenvolvido por Hsu (1978), a desfolha parcial no estádio de 9 folhas completas causou o atraso do pendoamento e da emissão dos estilo-estigmas, além de reduzir a produção em $42 \%$. Outros componentes, como o sistema radicular, colmos, espigas, altura da planta e altura da espiga também foram significativamente afetados.

Para Frey (1981), a retirada de 50\% dos limbos foliares na época de emissão de $50 \%$ dos pendões ocasionou sensível redução da taxa de acúmulo de matéria seca da parte aérea e da massa seca da espiga, por proporcionar um menor período para o enchimento de grãos.

Efeitos na produção de grãos ocasionados por 0, 25, 50, 75 e 100\% de desfolha em plantas de milho foram avaliadas por Britz (1982). Concluiu o autor que desfolhações extensivas durante o período de crescimento ativo da folha diminuíram o número de grãos por espiga, ao passo que a remoção de folhas, após a polinização, diminuiu o peso de grãos e o período para seu enchimento. Ainda, de forma geral, os efeitos se ampliaram com o aumento da desfolha efetuada além do período de $40 \%$ do pendoamento, sendo mais notório em épocas úmidas do que em épocas secas.

Resultados semelhantes foram obtidos por Diaz (1983), onde a desfolha durante o florescimento causou a maior redução de produção $\left(149 \mathrm{~kg}_{\text {g.ha }}{ }^{-1}\right)$ comparando com o tratamento testemunha. Os componentes da produção afetados pela desfolha no estádio mencionado foram o número de grãos por planta, número de espigas por planta, comprimento da espiga e peso de 1000 grãos.

Vasilas \& Seif (1985) procedendo a remoção de folhas em duas linhagens e em seis híbridos simples, em níveis relativos a 0,50 e 100\% de desfolha nos estádios de 7 folhas, 14 folhas, antese, grão leitoso e grão com o dente formado, observaram que a desfolha completa na antese, reduziu a produção em 100\% em todos os materiais. 
Hammond \& Pendleton (1964) avaliaram os efeitos de dez tratamentos de desfolha em milho, a partir da emergência do pendão, com o objetivo de determinar a importância relativa da posição da folha na produção de grãos, peso de grãos, número de grãos e conteúdo de proteínas e óleo do grão. Observaram os autores que a remoção das folhas superiores afetou a produção mais drasticamente que a remoção de folhas inferiores mesmo estas compreendendo a maior área foliar relativa. A análise dos componentes da produção mostrou que as reduções na produção foram devidas, principalmente, à diminuição no número de grãos do que ao peso de grãos.

A participação de folhas na produção e a distribuição da matéria seca em milho, após o florescimento, também foram avaliadas por Alisson \& Watson (1966). A análise dos resultados evidenciou que a maior parte do acúmulo de matéria seca após o florescimento foi proporcionado pelas folhas superiores. As cinco folhas superiores, as quatro medianas e as seis basais representavam, respectivamente, 26,42 e $32 \%$ da extensão da área foliar, sendo a contribuição estimada dos três grupos de folhas mencionados para a produção de matéria seca da planta corresponde a 40, 45 e 15\%, respectivamente. A diminuição do peso do colmo causado pela desfolha, segundo os autores, sugeriu que a matéria seca previamente armazenada foi translocada para o grão. Entretanto, a produção da matéria seca depois do florescimento é mais que suficiente para a plena formação e enchimento dos grãos e a fotossíntese antecedente a esta época pouco contribui para tal evento.

Diaz (1983) avaliando os efeitos da desfolha em milho branco meio-dente conclui que as folhas medianas e superiores contribuíram com $80 \%$ do total de matéria seca acumulada no grão, sendo que os fotossintetizados presentes na parte inferior da planta, após a emergência dos estilos-estigmas, foram translocados para as raízes.

A dinâmica de distribuição e utilização de assimilados em 3 posições de folhas, a saber: a. folha cuja espiga está inserida; b. terceira folha acima da espiga e c. abaixo da espiga, foi determinado por Fairey \& Daynard (1978) aos 10 dias após a emergência dos estilo-estigmas, mediante a técnica de plantas marcadas com carbono 14. Os resultados obtidos evidenciaram que a taxa inicial de translocação de assimilados (principalmente açúcares) das lâminas foliares aumentou com a altura da folha no dossel da cultura. 
Entretanto, aos 21 dias após a marcação, nenhuma diferença na retenção de ${ }^{14} \mathrm{C}$ foi denotada para as várias posições das folhas. O carbono incorporado por (b) foi recuperado em aminoácidos livres, amido e ácidos orgânicos por um período maior daquele incorporado por (c) e (a). O armazenamento temporário de açúcares no tecido do colmo foi evidente para os três tratamentos de folha marcada. Ainda, segundo os autores, parte do carbono incorporado pelas folhas inferiores, provavelmente, deva ter sido ciclado através do sistema radicular e retornado à parte aérea na forma de compostos nitrogenados.

A desfolha pode também afetar a formação do grão, visto que a retirada das folhas acima da espiga aos 12 e 24 dias após 50\% da emissão dos estilo-estigmas, segundo Jones \& Simmons (1983), promoveu a redução do desenvolvimento do grão e a duração do período de enchimento, principalmente na primeira época de desfolha.

Tollenaar \& Daynard (1978), objetivando avaliar o efeito da remoção de folhas na acumulação de matéria seca e teor de umidade dos grãos e taxa de formação da camada preta, submeteram plantas de milho à desfolha no florescimento e em intervalos subseqüentes de 2 semanas até a $6^{\text {a }}$ semana. Concluíram os autores que o número de grãos foi consideravelmente afetado pela retirada das folhas durante as duas primeiras semanas após o florescimento, enquanto que a desfolha tardia afetou principalmente o peso de grãos. Ainda, constataram que o teor de sólidos solúveis no colmo decresceu rapidamente após a remoção de folhas, indicando uma utilização acelarada de carboidratos solúveis contidos no colmo para o enchimento de grãos.

Da mesma forma, Daynard et alli (1969) já haviam reportado a evidência de nítida redução no peso seco do colmo, com início em 2 a 3 semanas depois da emergência de 50\% dos estilo-estigmas, correspondente ao período de maior acúmulo de matéria seca pela espiga. Contudo, em decorrência da participação deferenciada de grupos de folhas presentes na planta de milho na determinção da produção, a retirada de folhas em estádios iniciais de desenvolvimento da espécie considerada pode não afetar a produção final.

Quando a desfolha consistiu na remoção de folhas superiores de plantas em floração, a maioria dos resultados apresentados evidenciou significativa queda de 
produção, demonstrando a importância das folhas do ápice da planta no rendimento final. Dos componentes da produção mais afetados pela desfolha nesse período, destacam-se o número, comprimento e peso de espigas, além do número e peso de grãos.

O conceito atual de um genótipo moderno prevê a existência de um grande número de folhas acima da espiga com lâminas eretas, e planas na região mediana, aumentando a eficiência na utilização da energia radiante. Segundo Fornasieri Filho (2000), as folhas acima da espiga são responsáveis por cerca de 50 a $80 \%$ da matéria seca acumulada nos grãos. Porém, Magalhães \& Paiva (1993) ressaltam que, apesar da melhor interceptação de luz nesses genótipos modernos, muitos deles podem apresentar a limitação para a produção de grãos relacionada diretamente com sua habilidade em mobilizar, translocar e armazenar os fotoassimilados nos grãos e não na capacidade de sintetizar metabólitos (relações fonte/dreno), referindo-se ao modo de partição de fotoassimilados. Na verdade, a capacidade dos grãos (dreno) em alocar e utilizar os fotoassimilados produzidos (fonte) e as inter-relações entre esses fatores determinam o potencial de rendimento da cultura de milho (Magalhães \& Jones, 1990a; Magalhães \& Jones, 1990b).

Fancelli (1988), em experimento de campo, submeteu plantas de milho à desfolha das 5 folhas superiores e em 5 épocas diferentes. Concluiu o autor que quando a desfolha ocorre próxima a época do florescimento ela promove uma significativa queda na produtividade da cultura, principalmente pela redução do comprimento de espigas, peso de espigas e peso de grãos.

\subsection{Assimilação de dióxido de carbono e eficiência quântica da fotossíntese}

Cerca de $90 \%$ da matéria seca acumulada pela planta de milho provém da fixação atmosférica de $\mathrm{CO}_{2}$ pelo processo de fotossíntese (Magalhães \& Paiva, 1993).

A capacidade do milho em produzir grãos é dependente da habilidade da cultura para assimilar $\mathrm{CO}_{2}$. A assimilação de dióxido de carbono pode ser medido diretamente em nível de folha (A) e indiretamente em nível de dossel pela eficiência do uso da radiação (RUE) (Muchow \& Sinclair, 1994). 
Híbridos de milho cultivados até a colheita (115 dias) em câmara de crescimento, objetivando a determinação dos padrões de respiração e fotossíntese, foram avaliados por Ruget et al. (1981). Notaram os autores que a respiração total atingiu valor máximo por ocasião do pendoamento, ao passo que a fotossíntese máxima ocorreu poucos dias antecedentes à manifestação da área foliar máxima.

Para Pearson et al. (1984) o valor máximo da fotossíntese líquida do conjunto de folhas de milho foi obtido na antese, sendo ainda detectadas diferenças significativas entre genótipos durante o enchimento de grãos. Ainda, mudanças de curta duração, constatadas no transcorrer do ensaio, não foram relacionadas com a concentração de nitrato ou concentração de $\mathrm{N}$ total no interior da folha.

Williams (1985), avaliando a taxa fotossintética líquida, a condutância estomática e intracelular em folhas de milho em sua porção distal, após o florescimento, observou que o valor máximo da taxa líquida de assimilação de $\mathrm{CO}_{2}$ correspondeu a $30 \mu \mathrm{molCO} 2 \cdot \mathrm{m}^{-2} \cdot \mathrm{s}^{-1}$, decrescendo do topo da planta para as folhas de posição mais baixa. Comportamento semelhante também foi constatado com condutância estomática e condutância intracelular, sendo a taxa líquida de assimilação de $\mathrm{CO}_{2}$ foi mais eficientemente correlacionado à concentração interna de $\mathrm{CO}_{2}$ que à condutância estomática. Os dados também sugerem que um incremento da concentração celular de $\mathrm{CO}_{2}$ com a idade da folha pode ser uma característica comum de desenvolvimento de plantas $\mathrm{C} 4$.

Para Tsai (1982), no milho, a eficiência da distribuição de assimilados provoca aumento considerável na produção. Em sistemas de produção de milho tropical, a produção de grãos é menor do que aquela obtida em ambientes temperados devido à ineficiente partição de fotoassimilados. Ainda, segundo o autor, o decréscimo na altura da planta, área foliar acima da espiga e o tamanho do pendão poderiam incrementar a eficiência da distribuição equilibrada de fotoassimilados em milhos tropicais.

Vários autores afirmam que o rendimento de grãos de milho é limitado, principalmente, pela capacidade de suprimento de assimilados da fonte produtora (Tollenar \& Daynard, 1978; Schoper et al., 1982), enquanto outros consideram a capacidade dos grãos em armazenar os fotoassimilados disponíveis como causa limitante 
ao rendimento de grãos (Magalhães \& Jones, 1990a; Magalhães \& Jones, 1990b). Segundo esses últimos autores, a limitação dos grãos em acumular biomassa poderia estar ligada ao potencial genético da planta em estabelecer quantidade de drenos reprodutivos. Considerando que o número de grãos está estreitamente relacionado ao rendimento final de grãos de milho (Cirilo \& Andrade, 1994b), condições desfavoráveis de ambiente durante o crescimento de grãos podem causar abortamento destes (Jacobs \& Pearson, 1991). A diminuição do número de grãos resulta em redução da capacidade dos drenos em mobilizar fotoassimilados.

Durante o crescimento de grãos, que genericamente situa-se entre a fertilização e a maturação fisiológica, há uma fase linear, após uma fase "lag", que se estende até imediatamente antes da maturação fisiológica, em que mais de $90 \%$ da massa seca do grão é acumulada (Johnson \& Tanner, 1972; Tollenaar, 1977). Nesse período de intenso acúmulo de massa seca, tanto a translocação dos fotoassimilados pré-existentes, quanto a fotossíntese corrente contribuem cada uma com percentuais diferentes para aumento de massa seca do grão. A contribuição percentual de fotoassimilados de cada uma dessas fontes (partição), para o acúmulo de massa seca total do grão, é afetada pela quantidade de radiação interceptada, pela taxa de crescimento da cultura no florescimento e pelo tempo em que os grãos permanecem acumulando massa seca (Grant, 1989; Aluko \& Fisher, 1988; Tollenaar, 1977; Cirilo \& Andrade, 1994).

Sinclair \& Muchow (1994) com a finalidade de explicar a queda da RUE em função do teor de $\mathrm{N}$ foliar acima do esperado pelas análises teóricas, fizeram a hipótese que em baixos teores de $\mathrm{N}$ foliar não só a assimilação de $\mathrm{CO}_{2}$ estaria limitando a RUE, mas também a eficiência quântica seria um fator de redução. Tal hipótese é corroborada pelos resultados de Goudriaan \& van Keulen (1979) e Khamis et al. (1990) que observaram a queda da eficiência quântica em folhas de milho de plantas crescidas em solução nutritiva com deficiência de N. E ainda com Thiagarajah et al. (1990) que na comparação de folhas de milho com diferentes idades obtiveram redução tanto na troca de $\mathrm{CO}_{2}$ quanto na eficiência quântica com a idade. Segundo Sinclair \& Muchow (1994) observações experimentais da eficiência quântica de espécies $\mathrm{C}_{4}$ parece necessário em vista da hipótese da grande influência na RUE dos baixos teores de $\mathrm{N}$ foliar. 
$\mathrm{Na}$ análise de sensibilidade do modelo Hibrid-maize para os parâmetros que influenciam a produção de matéria seca, Yang et al (2004) observaram valores para a eficiência quântica variando entre 9 e $16 \mathrm{~g} \mathrm{CO}_{2} \mathrm{MJ}^{-1}$. Os autores, por último citado, consideraram a faixa de valor superior ao encontrado na literatura para plantas $\mathrm{C}_{4}$ como o milho, e sugeriram futuras investigações sobre o parâmetro.

\subsection{Modelagem em agricultura}

De uma forma geral, as funções de produção usadas para recomendações agrícolas têm sido baseadas em análises de correlação e regressão. O uso desse tipo de análise tem auxiliado no conhecimento qualitativo das variáveis e suas interações envolvidas nos sistemas de produção das culturas e também contribuído para o progresso de ciência da agricultura. No entanto, a informação qualitativa obtida nesse tipo de análise é específica para determinados ambientes, havendo usualmente poucas considerações a respeito dos processos físicos e fisiológicos envolvidos (Jame \& Curtforth, 1996).

A interação entre as plantas e o ambiente envolve uma complexidade de processos físicos, químicos e biológicos. A fim de se obter melhor conhecimento das respostas da cultura ao ambiente, modelos de simulação são utilizados como ferramenta de grande potencial na área de sistemas cultivados, permitindo o estudo e entendimento do conjunto, estimando a performance da cultura em diferentes áreas e situações (Tojo Soler, 2004).

No Brasil o rendimento médio da cultura de milho gira em torno de $2.700 \mathrm{~kg} . \mathrm{ha}^{-1}$, valor muito aquém do desejado. Práticas corretas de manejo podem ser determinantes para a condução adequada da lavoura, assim sendo todas as informações sobre elementos bióticos (pragas, doenças e plantas daninhas), clima, planta, solo e a interação entre esses fatores podem auxiliar tanto o produtor quanto o pesquisador no desenvolvimento da cultura (Dourado Neto, 1999).

Costa (1997), com o objetivo de facilitar o entendimento da definição de modelos de simulação distingue três termos: sistemas, modelos, e simulação. Sistemas é uma parte limitada da realidade que contém vários elementos inter-relacionados; modelo é 
uma representação simplificada de um sistema; simulação é a arte de construir modelos matemáticos e de estudar suas propriedades em relação às do sistema (De Wit, 1982).

Jame \& Cutforth (1996) definem modelo como uma série de equações matemáticas, as quais descrevem um sistema físico, no caso, sistema solo-plantaatmosfera. O modelo simula uma cultura pela estimativa do desenvolvimento e crescimento de seus componentes, como folhas, raízes, caules e grãos. Portanto, um modelo de simulação de crescimento de cultura não somente estima a biomassa total ou a produção na colheita, mas também, inclui informações quantitativas sobre a maioria dos processos envolvidos no crescimento e desenvolvimento da planta.

Segundo Monteith (1996), os modelos de simulação de cultura podem ser definidos como conjunto de equações para estimar o crescimento, desenvolvimento e produção de uma cultura a partir de uma série de coeficientes fitogenéticos e variáveis ambientais. Os modelos permitem analisar detalhadamente os diversos componentes da produção, possibilitando uma visão integrada de sua participação no sistema.

Thornley (1976) relata que modelos são equações ou o conjunto delas, podendo representar quantitativamente as suposições e hipóteses idealizadas sobre o sistema real.

Devido à expansão do desenvolvimento e utilização dos modelos no mundo, tornou-se necessário a classificação dos mesmos. Vários sistemas de classificação, levando-se em consideração principalmente a arquitetura e a fisiologia dos modelos foram desenvolvidos. Sendo assim, observa-se uma aceitação quase completa na literatura científica mundial de uma primeira classificação dos modelos em duas categorias principais: modelos empíricos e modelos mecanísticos (Costa, 1997).

Modelos empíricos são modelos que se baseiam simplesmente na interação quantitativa entre os elementos considerados no mesmo. Nesses modelos as análises dos resultados não se baseiam na explicação dos fenômenos envolvidos, mas na relação entre os elementos. Normalmente, tais modelos fundamentam-se em relações derivadas a partir de análise de regressões e, geralmente, necessitam de grande número de dados para seu desenvolvimento (Costa, 1997). Em sendo uma mera descrição matemáticaestatística dos dados, os modelos empíricos não consideram o entendimento científico do sistema. São modelos que representam grandes restrições quanto a extrapolação de 
seus resultados, mas no entanto tem grande potencial na previsão de certos fenômenos, como por exemplo, produtividade de culturas, dentro da região em que foi desenvolvido (Costa, 1997).

Modelos mecanísticos são modelos que tem sua estrutura baseada na descrição do processo que ocorre no sistema real considerado, ou seja, existe a tentativa de se considerar os princípios físicos e biológicos que no sistema. Tais modelos procuram entender o que ocorre no níve i, baseado nos processos que ocorrem no nível i-1. Tais modelos apresentam grandes dificuldades na obtenção dos dados necessários para o seu desenvolvimento. Por outro lado, eles apresentam pouca restrição a extrapolação geográfica e espacial dos resultados. É necessários que se entenda o conceito de modelo mecanístico em seu sentido mais amplo, ou seja, uma tentativa de juntar os processos do sistema de uma forma mecanística, mas para tal, muitas vezes incorporam submodelos empíricos (Costa, 1997).

De acordo com Dourado Neto (1996), os modelos matemáticos podem ser determinísticos, quando prevêem com exatidão e precisão o comportamento de um dado fenômeno de interesse em sistemas reais, heterogêneos e anisotrópicos ou modelos estocásticos, quando permitem prever apenas com precisão o comportamento em estudo, onde a exatidão é verificada estatisticamente associada a um nível de significância.

De acordo com Boote et al. (1996) e Hoogeboom (2000), os esforços despendidos para a construção de modelos dados a sua complexidade se justificam pelas seguintes razões: (i) são ferramentas importantes para sumarizar o conhecimento científico; (ii) auxilia os agricultores na tomada de decisões de manejo; (iii) subsidia governos na elaboração de políticas de planejamento agrícola, (iv) o grande potencial didático do desenvolvimento de modelos e (v) a orientação de pesquisas e a racionalização do uso de experimentos convencionais.

Segundo Munakata (1995), os estudos de simulação de crescimento das culturas podem ser definidos em duas linhas: (i) aquela que considera a estrutura do dossel da planta (características para a interceptação da luz); e (ii) a dinâmica da produção de fitomassa seca (crescimento). 
Muitos modelos de fotossíntese e partição de carbono estão em desenvolvimento com o objetivo de estabelecer relações quantitativas entre fatores ambientais, características do dossel da cultura, ontogenia, taxas de fotossíntese e partição de fotoassimilados entre os vários órgãos da planta (Sing, 1994).

Diferentes abordagens são dadas para simular o desenvolvimento e crescimento de milho. Modelos genéricos descrevem os processos de assimilação, respiração, desenvolvimento e crescimento sem considerar a espécie da cultura, e são ajustados para simular as características fenológicas e fisiológicas de culturas específicas como milho, arroz, ou batata (Yang et al, 2004). Exemplos de modelos genéricos de cultura incluem SUCROS, WOFOST and INTERCOM (Van Ittersum et al., 2003), STICS (Brisson et al., 2003), e CropSyst (Stöckle et al., 2003). Em comparação aos modelos genéricos, outros modelos são desenvolvidos para simular o desenvolvimento e crescimento de determinada espécie cultivada. O modelo CERES-Maize e sua implementação no DSSAT (Jones \& Kiniry, 1986; Jones et al., 2003), e o modelo Muchow-SinclairBennett (MSB) (Muchow et al., 1990) são exemplos de modelos específicos para o milho.

Em modelos genéricos tal como WOFOST (Van Diepen et al., 1989) e INTERCOM, o crescimento dos órgãos da planta é impulsionado principalmente pela disponibilidade de assimilados provenientes da simulação da fotossíntese do dossel, e ambas respiração de crescimento e manutenção são explicitamente contabilizadas para determinar a produção de matéria seca. Tais modelos abordam de forma mais mecanística a fotossíntese no dossel. Partem da assunção de que existe uma proporcionalidade entre a capacidade fotossintética e radiação incidente, definida por equação exponencial ou que descreve uma hipérbole retangular, assumindo resposta de natureza enzimática, conforme a curva de Michaelis-Mentem (Medlyn et al., 2003). Eles incorporam variáveis como taxa máxima de assimilação de $\mathrm{CO}_{2}\left(\mathrm{~A}_{\mathrm{m}}\right)$, eficiência quântica $(\varepsilon)$, coeficiente de extinção da luz $(\mathrm{k})$, radiação fotossinteticamente ativa interceptada (PARi) e índice de área foliar (IAF). O dossel é estratificado em camadas e o PARi e a correspondente assimilação de $\mathrm{CO}_{2}$ é computado por camada. A assimilação bruta final do dossel é então obtida pela integração total das camadas. 
Em específicos modelos de milho tal como MSB e CERES-Maize, o crescimento dos órgãos é principalmente impulsionado pela temperatura, e a produção de matéria seca é computada diretamente da radiação solar absorvida, por meio de um valor fixado para eficiência de uso da radiação (RUE), que leva em conta implícito o custo da respiração - O emprego da RUE em modelos é baseado no trabalho de Monteith (1977) que encontrou uma relação linear entre radiação fotossintéticamente ativa absorvida $\left(\mathrm{PAR}_{\mathrm{a}}\right)$ e produtividade da parte aérea de culturas anuais - $\mathrm{O}$ uso de um valor fixado de RUE como sendo o parâmetro determinante da acumulação de matéria seca em modelos de simulação de culturas vem sendo questionado, porque um valor fixado de RUE incorpora um número de processos fisiológicos, onde cada um é sensível às condições ambientais e ao estado da cultura (Goudriaan \& Van Laar, 1994; Loomis \& Amthor, 1999). Portanto, RUE é variável dinâmica e integradora, sensível a intensidades de luz e temperatura. Modelos que contam com um valor fixado de RUE podem ser menos sensíveis a variações nas condições climáticas e do estado fisiológico das plantas (Yang, et al., 2004). Por exemplo, Edmeades and Bolanos (2001) especularam que o valor padrão usado em CERES-Maize (4,33g.MJ ${ }^{-1} \mathrm{PAR}$ ) pode ser muito elevado para regiões tropicais onde altas temperaturas pode resultar em grande respiração, e picos de intensidade de radiação levar a redução da fotossíntese pela foto-oxidação. 


\section{MATERIAL E MÉTODOS}

\subsection{Local e época de realização do experimento de campo}

O experimento de campo foi montado no Campo Experimental sob a égide do Departamento de Produção Vegetal da Escola Superior de Agricultura "Luiz de Queiroz" ESALQ/USP, Município de Piracicaba, SP (latitude: 2242’30’'S; longitude: 47³8'00, altitude: $546 \mathrm{~m}$ ).

A área onde foi implantado o experimento se caracteriza por apresentar topografia plana a levemente inclinada. O solo é classificado como terra roxa estruturada, de boa fertilidade e propriedades físicas.

A área vinha de um pousio de seis meses.

O plantio do experimento foi realizado no dia 22 de setembro de 2003.

\subsection{Genótipos utilizados}

O experimento contou com três híbridos desenvolvidos pela Embrapa - Empresa Brasileira de Pesquisa Agropecuáia, sendo dois híbridos simples (BRS 1010 e BRS 1001) e um híbrido triplo (BRS 3003).

De acordo com a Embrapa, o BRS 1010 apresenta as seguintes: resistência à Phaeospheria e moderadamente resistente 'a mancha de Cercósopora, duas das principais doenças da cultura do milho; alta eficiência na utilização de fósforo;

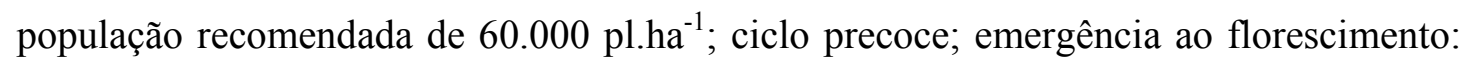
64 dias; emergência à maturação: 126 dias; porte da planta: baixo (1,98 a 2,07m); arquitetura de parte aérea: ereta; altura da espiga: baixa $(1,01$ a 1,08m); grão semiduro; e coloração do endosperma laranja.

Segundo a Embrapa, o BRS 3003 apresenta as seguintes características: alta produtividade e estabilidade de produção; população recomendada de 55.000 pl.ha $^{-1}$; 
ciclo precoce, emergência ao florescimento: 59 dias; emergência a maturação: 126 dias; porte da planta médio/baixo (2,09 a 2,15m); arquitetura de parte aérea: semi-ereta; altura da espiga: média $(1,01$ a 1,16m); boa resistência ao acamamento.

De acordo com a Embrapa, o BRS 1001 apresenta as seguintes características: alta uniformidade de plantas e espigas; resistente à Cercospora, população de 55.000pl.ha ${ }^{-1}$; ciclo precoce; emergência ao florescimento: 59 dias; emergência à maturação: 130 dias; altura: 2,20m; arquitetura de parte aérea plana; altura espiga: $115 \mathrm{~m}$; resistente ao acamamento.

Os três híbridos pertencem a uma mesma base genética, e são considerados muito semelhantes, principalmente quanto ao ciclo. O objetivo quando da escolha dos híbridos foi isolar apenas a característica contrastante da arquitetura de parte aérea existente entre eles.(ereta, semi-ereta e plana).

As sementes foram doadas pela Embrapa - Centro Nacional de Milho e Sorgo Sete Lagoas - MG.

\subsection{Delineamento experimental, dimensão de parcelas e população e distribuição de plantas}

O delineamento experimental utilizado para orientar a implantação do experimento no campo foi o inteiramente casualizado, com quatro repetições, onde os híbridos BRS 1010; BRS 3003 e BRS 1001 foram considerados os tratamentos. Os tratamentos foram sorteados nas parcelas.

As dimensões da parcela foram de $12 \times 12 \mathrm{~m}$, compreendendo uma área de $144 \mathrm{~m}^{2}$. O espaçamento entre linhas foi de $0,8 \mathrm{~m}$ e a população final de 66.000 pl.ha $^{-1}$

Os dados foram analisados aplicando-se ou Teste de Tukey ou Teste-t de comparação de médias, por meio de programas estatísticos computacionais (StatUNESP e Origin 6.0)

\subsection{Condução do experimento de campo}

A área, vinda de um pousio de 6 meses, sofreu um preparo convencional, constituído de 2 gradagens pesadas e uma gradagem niveladora. Em seguida, procedeu- 
se mecanicamente a abertura de pequenos sulcos, com profundidade variando em torno de $4 \mathrm{~cm}$.

Uma amostra de semente de cada híbrido foi coletada do saco de sementes para a determinação da massa seca de 100 sementes.

Antes de serem plantadas, as sementes foram tratadas com inseticida para evitar danos de pragas de solo. O produto comercial foi Futur, na dosagem de 2,0L/100kg de semente.

A adubação de base foi feita no fundo dos sulcos na dosagem de $450 \mathrm{~kg} \cdot \mathrm{ha}^{-1} \mathrm{da}$ fórmula 8-28-16. Tanto o adubo quanto as sementes foram distribuídos manualmente, com auxílio de "medidas" pré-preparadas (garrafa plática de água de $600 \mathrm{~mL}$ cortadas) que comportavam uma quantidade referente a uma linha, $15 \mathrm{~m}$. Após a distribuição do adubo e das sementes nos sulcos, estes foram fechados manualmente, com auxílio de pequenas enxadas. Após as operações de plantio foi aplicado herbicida pré-emergente, produto comercial Primestra Gold, na dosagem de $3 \mathrm{~L} \cdot \mathrm{ha}^{-1}$

Em razão de possíveis falhas de germinação, ataque de pragas e outros fatores de redução de estande, a densidade de semeadura foi para uma população de 1000.000pl.ha $\mathrm{pa}^{-1}$. Aos 10 dias após a emergência foi feito um raleamento manual das plantas nas parcelas para ajustar a população de plantas para 66.000pl.ha ${ }^{-1}$.

Duas adubações de cobertura, nos estádios de 4 folhas- 19/10/2003 e de 8 folhas01/11/2003, foram feitas aplicando-se uma dosagem de $40 \mathrm{~kg}$ de $\mathrm{N}$ e $20 \mathrm{~kg}$ de $\mathrm{K}_{2} \mathrm{O}$, manualmente. No decorrer do ciclo foram feitas ainda duas aplicações foliar de solução completa com micronutrientes.

Para o controle da lagarta do cartucho, foram feitas 4 aplicações alternando os seguintes inseticidas comerciais (Lorsban e mistura de Decis + Fastac) As aplicações foram tratorizadas.

A irrigação foi montada logo após o plantio e o sistema de irrigação foi do tipo aspersão convencional. A umidade do solo foi monitorada com duas baterias de tensiômetros $(10$ e $20 \mathrm{~cm})$ e o momento de irrigar definido pelo potencial crítico. A lâmina aplicada variou em torno de $15 \mathrm{~mm}$. O período do experimento foi marcado com precipitações em torno da média para o período (anexo 1). 




Figura 1 - Vista geral do experimento no campo

\section{5 Épocas de amostragem e estádios fenológicos}

Os estádios fenológicos foram acompanhados com verificação quase que diária da cultura de acordo com método citado por Fancelli \& Dourado Neto (2000).

A emergência de 50\% das plantas seu deu no dia 29/09. Os demais estádios avaliados e a ocorrência no tempo em relação à emergência foram: 4 folhas: 21 dias após a emergência (DAE); 8 folhas: 34 DAE; 12 folhas: 49DAE; florecimento: 64 DAE, grão leitoso: 80 DAE; grão pastoso: 100DAE; grão farináceo duro:114 DAE; ponto de maturidade fisiológico: 127 DAE.

As amostragens foram feitas em todos os estádios fenológicos mencionados acima, sempre se iniciando nas primeiras horas do dia.

\subsection{Assimilação de dióxido de carbono, eficiência quântica da fotossíntese e respiração}

A taxa de assimilação máxima de $\mathrm{CO}_{2}\left(\mathrm{~A}_{\mathrm{m}}\right)$, a eficiência quântica da fotossíntese $(\varepsilon)$ e a respiração de escuro foram medidas através do equipamento portátil LI-6400 da Li-Cor (LI-COR, Lincoln, NE). 
As medidas de taxa máxima de assimilação de $\mathrm{CO}_{2}$, eficiência quântica da fotossíntese e respiração foram feitas nos estádios fenológicos de 4 folhas, 8 folhas e 12 folhas. Foram analisadas quatro plantas (quatro folhas) por tratamento. No estádio de 8 folhas, foram analisadas folhas situadas no estrato médio superior e no estrato médio inferior do dossel, considerou-se o meio do dossel, a metade do comprimento que vai do primeiro nó acima do solo, na base da planta, a ponta da folha mais alta da parte aérea. No estádio de 12 folhas, foram analisadas folhas do terço superior do dossel, do terço médio do dossel e do terço inferior do dossel. A obtenção do comprimento para se estabelecer a divisão de terços segue o mesmo já descrito para 8 folhas.

As folhas analisadas no estádio de 4 folhas, estrato médio do estádio de 8 folhas e no terço superior no estádio de 12 folhas foram aquelas recém maduras. Foram feitas 4 repetições por tratamento. Cada repetição representa a medida de uma folha.

A respiração de escuro foi determinada com a luz da câmara do IRGA desligada. A eficiência quântica $(\varepsilon)$ representa o coeficiente ângular da reta de regressão obtida através da plotagem dos valores correspondente de densidade de fluxo de fótons fotossintéticos (PPFD) e a taxa de assimilação de $\mathrm{CO}_{2}$ (A). Os valores para PPFD foram $0,30,60,90,120$ e $150 \mu \mathrm{mol} \cdot \mathrm{m}^{-2} \cdot \mathrm{s}^{-1}$

A taxa de assimilação máxima de $\mathrm{CO}_{2}\left(\mathrm{~A}_{\mathrm{m}}\right)$ foi determinada com intensidade de luz saturante $\left( \pm 1900 \mu \mathrm{mol} . \mathrm{m}^{-2} \cdot \mathrm{s}^{-1}\right.$ de PPFD) e temperatura de $\pm 30^{\circ} \mathrm{C}$.

Foram tomados todos os cuidados quanto a calibração do equipamento e os procedimentos para uma boa análise. As medidas se iniciavam por volta da 8:30hs e terminavam por das $15: 30 \mathrm{hs})$

\section{7 Índice de área foliar e área foliar específica}

A determinação do IAF total e estratificado em "camadas" foi feito nos estádios de 4 folhas, 8 folhas, 12 folhas, florescimento, grão leitoso, grão pastoso e grão farináceo duro. Nestes estádios quatro plantas por tratamento (híbridos BRS 1010, BRS 1001 e BRS 3003) foram cortadas na base do colmo e levadas rapidamente até o laboratório. 
No laboratório as plantas foram, em cada amostragem, mantidas em sala climatizada, matendo-se a temperatura em torno de $17{ }^{\circ} \mathrm{C}$. A base dos colmos (corte) foram colocadas em baldes com água. Esse procedimento visou conservar ao máximo a turgescência da folhas.

Com exceção do estádio de 4 folhas, as plantas dos demais estádios foram subdivididas em camadas ou estratos, sendo que no estádio de oito folhas esta divisão foi feita em duas metades iguais no sentido do comprimento, e a partir do estádio de 12 folhas, em três partes iguais. A medida do comprimento para se efetuar a divisão foi estabelecido como sendo aquele que iniciou do $1^{\circ}$ nó visível do colmo à parte do limbo foliar situada mais distante verticalmente, tomando-se sempre o alinhamento do colmo.

Após a definição das camadas, as folhas foram cortadas com auxílio de tesoura e passadas no medidor fotoelétricas LI 3100 (Li-Cor, Nebraska, USA), para obtenção da área foliar.

Após a determinação da área foliar, as folhas foram acondicionadas em sacos de papel, que em seguida foram levados à estufa de secagem, com temperatura regulada para $68^{\circ} \mathrm{C}$. Após atingimento de peso constante, os sacos foram retirados da estufa e a massa das folhas determinada em balança anaílitica.

A área foliar específica (AFE) foi então determinada pela divisão da área das folhas pela massa das folhas, para cada estrato do dossel, e expressa $\mathrm{em} \mathrm{cm}^{2} . \mathrm{g}^{-1}$

O IAF da cultura foi calculado com base na média podenderada da AFE e da fitomassa seca de folhas.

\subsection{Fitomassa seca da parte aérea, partição e produtividade de grãos}

A determinação da fitomassa seca de parte aérea e a sua divisão em colmo, folhas, espiga (a partir de grão leitoso) e folha seca (a partir de grão pastoso) foram feitas em estádios de 4 folhas, 8 folhas, 12 folhas, florescimento, grão leitoso, grão pastoso e grão farináceo duro.

Nestes estádios, 1,5 metros de linha de cultura eram colhidos. As partes divididas e acondicionas em sacos de papel que em seguida eram levados até a estufa de secagem $\left(68^{\circ} \mathrm{C}\right)$, e deixados até que atingissem peso constante. A fitomassa seca de 
$1,2 \mathrm{~m}^{2}(1,5 \mathrm{mx} 0,8 \mathrm{~m})$ determinada em balança analítica foi então extrapolada para kg.ha ${ }^{-1}$ de fitomassa seca. Estes prodedimento se repitiram em todos os estádios.

A massa de folhas seca foi utilizada para se calcular o IAF de cada estádio fenológico através da AFE ponderada entre as camadas, obtida da amostragem de quatro plantas.

A produtividade de grãos foi determinada no ponto de maturidade fisiológico. Neste estádio $3 \mathrm{~m}$ de rua de cultura foi colido de cada parcela. As espigas foram debulhadas com auxílio de um debulhador manual. Uma amostra foi retirada para determinação da umidade do grão e a produtividade final foi expressa em $\mathrm{kg} \cdot \mathrm{ha}^{-1} \mathrm{de}$ grãos com $13 \%$ de umidade.

\subsection{Análise de crescimento quantitativo}

A taxa assimilatória líquida, a taxa de crescimento de cultura e a taxa de crescimento relativo nos foram calculadas através das equações descritas por Hunt (1982).

\subsection{Eficiência do uso da radiação}

O cálculo da eficiência do uso da radiação (RUE) foi feito para cada estádio de avaliação da fitomassa seca.

$$
R U E=F S a / P A R i
$$

em que RUE se refere à eficiência do uso da radiação de cultura $\left(\right.$ g.MJ $\left.{ }^{-1}\right)$, FSa à fitomassa seca da parte aérea produzida em um dia $\left(\mathrm{g} \cdot \mathrm{m}^{-2}\right.$ dia $\left.^{-1}\right)$ e PARi à radiação fotossinteticamente ativa interceptada pelo dossel vegetal $\left(\mathrm{MJ} \cdot \mathrm{m}^{-2} \cdot \operatorname{dia}^{-1}\right)$. A fração PAR referente a radiação global foi considerada de 0,45 .

\subsection{Coeficiente de extinção da luz}

O coeficiente de extinção da luz foi determinado através da equação baseada da

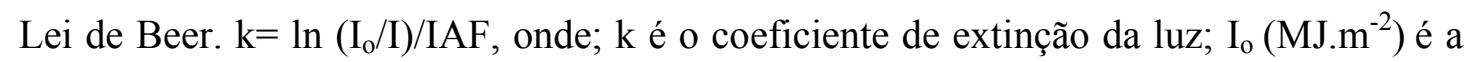
radiação que chega no topo da cultura, I $\left(\mathrm{MJ}^{-\mathrm{m}^{-2}}\right)$ é a radiação que é interceptada pelo dossel; IAF é o índice de área foliar. 
O k foi determinado nos dias das amostragens de IAF, ou no dia mais com predomínio de radiçaão de radiação solar direta (sem nuvens).

$\mathrm{O}$ valor calculado para $\mathrm{k}$ é média composta por dez momentos do dia (8:00 às $17: 00 \mathrm{~h})$

O valor de I foi determinado pela diferença entre o valor que chega no topo do dossel e o valor coletado pelo tubo solarímetro.

\subsection{Desfolhamento}

Ao final da antese, um ensaio foi montado na área experimental. Este ensaio teve como objetivo verificar a importância de cada terço de folhas do dossel na redução da produtividade da planta. Ele consistiu na retirada das folhas dos terços do dossel. Seis plantas de cada genótipo foram submetidas ao mesmo tratamento. Os tratamentos foram: sem o terço superior, sem o terço médio e sem o terço inferior. A folhas foram cuidadosamente recortadas, de modo que a preservar a sua posição ou posições no dossel. Por exemplo: se uma folha ocupasse tanto o terço médio quanto o terço superior de devido a sua extensão, e o tratamento fosse referente ao terço médio, somente o limbo ocupando o estrato médio seria retirado, mantendo-se a nervura principale para dar sustentação ao restante da folha.

Após o ponto de maturidade fisiológico o material as plantas foram colhidas e o rendimento por espiga (g.espiga ${ }^{-1}$ ) determinado com base de $13 \%$ de umidade.

\subsection{Coleta e análise dos dados meteorológicos}

Para a obtenção da radiação interceptada pela parte aérea dos híbridos, tubos solarímetros (Delta-T Divices Ltd., 0,97m) foram dispostos sob o dossel da cultura (Figuras 2 e 3). Em virtude de disponibilidade, cada híbrido contou com um par de tubos, que foram dispostos diagonalmente à direção da linha de semeadura, em posição Norte-Sul, através de duas ruas internas. Os tubos foram ligados a uma datalogger (21Xmicrologger: Campbell Scientific Ltd.) alimentada por uma bateria carregada através de placa solar. A datalogger foi programada para registrar valores a cada cinco minutos. A radiação global foi obtida de estação automática no posto meteorológico da ESALQUSP, tomou-se o cuidado de acertar a hora das duas datalogger (tubos solarímetros e 
piranômetro). Através de calibração prévia com o piranômetro do posto agrometeorológico da ESALQ/USP, os valores registrados de radiação em milivolts foram transformas em W.m ${ }^{-2}$. A integração no dia foi feita com programa computacional (Origin 6.0). Cosiderou-se 45\% da radiação global como sendo de PAR.
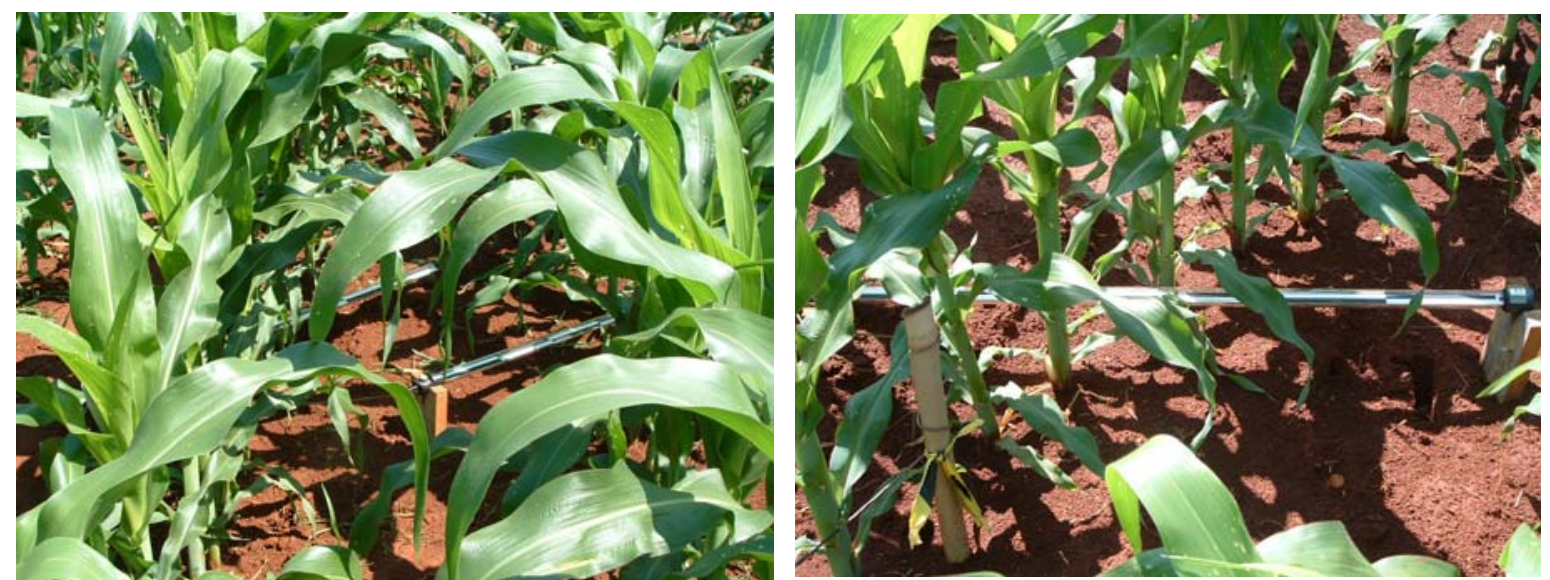

Figura 2 - Disposição dos tubos solarímetros sob a cultura
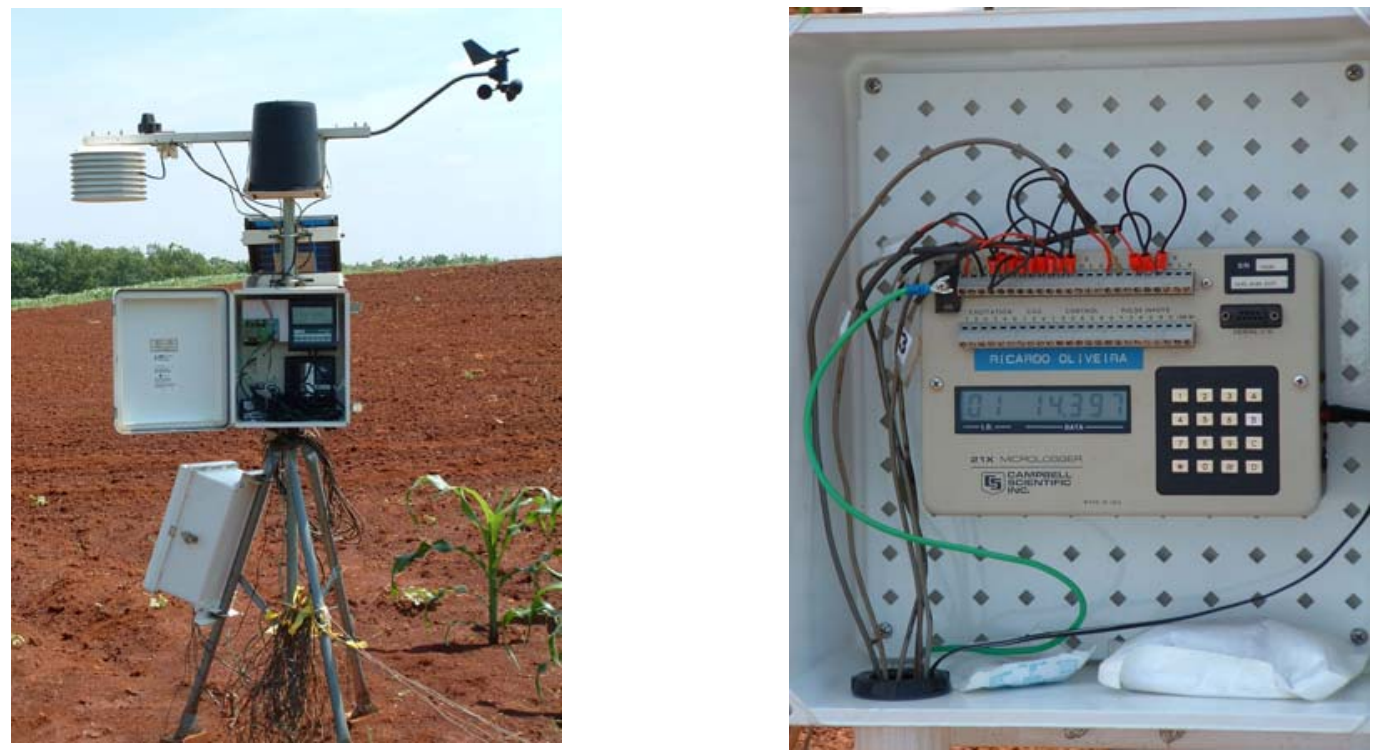

Figura 3 - Estação meteorológica automática e datalogger 


\section{RESULTADOS E DISCUSSÃO}

\section{1 Índice de área foliar}

A expansão da área foliar é de grande importância para a interceptação da luz e para a fotossíntese. A Figura 4 mostra a evolução do IAF da emergência ao estádio de grão farináceo duro dos três híbridos de milho avaliados, BRS 1001, BRS 1010, BRS 3003 .

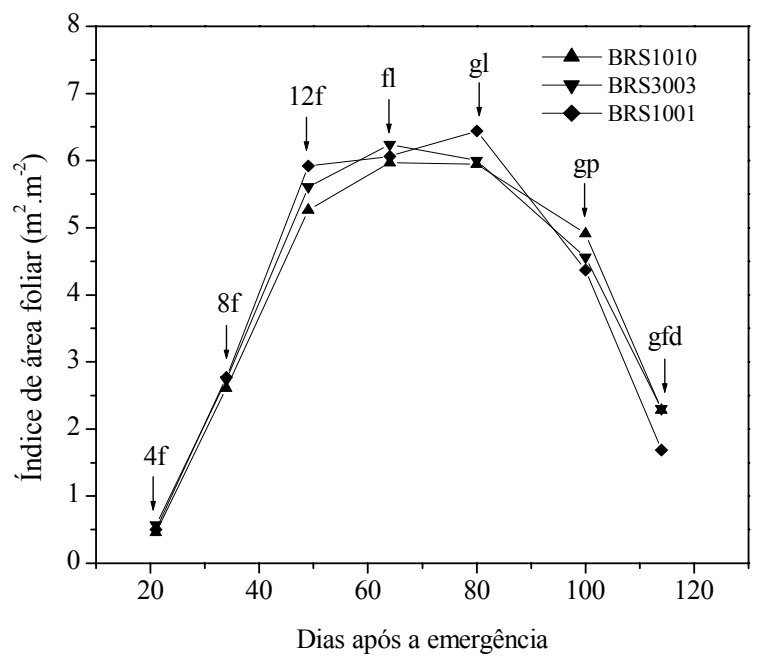

Figura 4 - Índice de área foliar de três híbridos de milho da emergência ao estádio de grão farináceo duro

A evolução do IAF no tempo segue o padrão característico de plantas anuais, com uma fase inicial lenta que vai da emergência até o estádio de 4 folhas (21 DAE), seguida de uma fase de rápido crescimento, de 4 folhas até o estádio de 12 folhas (49 
DAE). A terceira fase é caracterizada pela estabilização do IAF em torno do valor máximo atingido, compreendido entre o estádio de 12 folhas e o estádio de grão leitoso (80 DAE), e a última fase, que se inicia com a queda do índice de área foliar e termina no fim do ciclo da cultura (Figura 4).

Os genótipos BRS 1010 e BRS 3003 atingiram o pico máximo do IAF no estádio de florescimento. Para enquanto o genótipo BRS 1001, foi observado IAF máximo no estádio de grão leitoso (Figura 4). Os valores máximos observados de IAF foram de 5,96; 6,24 e 6,44 para os genótipos BRS 1010, BRS 3003 e BRS 1001, respectivamente.

Nos sete estádios fenológicos avaliados, os valores médios de IAF total dos três genótipos não mostraram diferença significativa entre eles quando foram submetidas ao teste de Tukey em nível de $5 \%$ de probabilidade (Tabelas 1 a 7 ).

Mesmo não apresentando diferença estatística nos valores médios de IAF, uma análise conjunta (com outros parâmetros avaliados no experimento) nos permite explorar pequenas diferenças, que podem se traduzir em efeitos significativos quando integrados no ciclo dos híbridos.

Tabela 1. Teste de Tukey para médias de IAF $\left(\mathrm{m}^{2} \cdot \mathrm{m}^{-2}\right)$ de três híbridos de milho com diferentes arquiteturas de parte aérea. Estádio de 4 folhas - 21 DAE

\begin{tabular}{cccc}
\hline Híbridos & IAF & DMS & CV\% \\
\hline BRS 1010 & $0,47 \mathrm{~A}^{1}$ & 0,18 & 17,5 \\
BRS 3003 & $0,57 \mathrm{~A}$ & & \\
BRS 1001 & $0,50 \mathrm{~A}$ & &
\end{tabular}

${ }^{1}$ Médias seguidas pela mesma letra não diferem estatisticamente entre si $(p \leq 0,05)$

DMS: Diferença Mínima Significativa

CV (\%): Coeficiente de Variação

No estádio de 4 folhas (Tabela 1) o híbrido BRS 3003 apresentou o maior valor médio de IAF, com a maior diferença na comparação com o genótipo BRS 1010 (Tabela 1). Essa superioridade ao genótipo BRS 1010 é corroborada pela diferença estatisticamente significativa da produtividade de fitomassa seca de parte aérea (Tabela 10).O arranque inicial mais rápido do $\mathrm{BRS} 3003$ pode ser explicado, em parte, pela 
maior quantidade de reservas contida nas sementes usadas para implantação dos experimentos. A massa de 100 sementes secas para cada um dos híbridos foi de 36,9g; 26,4g, 25,6g para os genótipos BRS 3003, BRS 1001 e BRS 1010, respectivamente.

Tabela 2. Teste de Tukey para médias de IAF $\left(\mathrm{m}^{2} \cdot \mathrm{m}^{-2}\right)$ e espessura de estratos $(\mathrm{cm})$ do dossel vertical de três híbridos de milho com diferentes arquiteturas de parte aérea. (A) estrato médio superior e (B) estrato médio inferior. Estádio de 8 folhas -34 DAE

\begin{tabular}{cccccc}
\hline Estrato & BRS 1010 & BRS 3003 & BRS 1001 & DMS & CV \\
\hline A & $2,08 \mathrm{~A}^{1}$ & IAF & & & \\
B & $0,58 \mathrm{~A}^{2}$ & $0,45 \mathrm{~B}$ & $0,34 \mathrm{C}$ & 0,06 & 7,4 \\
Total & $2,61 \mathrm{~A}^{1}$ & $2,73 \mathrm{~A}$ & $2,77 \mathrm{~A}$ & 0,54 & 9,9 \\
& & Espessura & & \\
A,B & 53,9 & 59,4 & 53,4 & \\
Total & 107,8 & 118,8 & 106,8 & \\
\hline
\end{tabular}

${ }^{1}$ Médias seguidas pela mesma letra na linha não diferem estatisticamente entre si $(\mathrm{p} \leq 0,05)$

${ }^{2}$ Médias seguidas de letras diferentes na linha diferem estatisticamente entre si $(p \leq 0,01)$

A expansão foliar do híbrido BRS 1001 entre os estádios de florescimento e grão leitoso pode ter consumido fotoassimilados que poderiam ser destinados ao enchimento de grãos. Mesmo a despeito de ter prolongado por mais tempo a expansão da área foliar, a queda do IAF, verificada logo após o alcance do seu máximo, é mais pronunciada nesse genótipo (Figura 4 e Tabelas 5 e 6). Tal queda é provocada pela senescência das folhas basais do dossel da cultura. A senescência pode ter sido causada pelo autosombreamento excessivo das folhas basais.

Embora o maior valor do IAF e a data em que ele foi atingido nos mostre uma tendência para a ordem de maturação final, em uma análise comparativa, o híbrido BRS 1001 foi o primeiro a atingir o ponto de maturidade fisiológico, tal ocorrência foi causada pela maior taxa de senescência da folhas (Tabela 16). Situação semelhante foi 
observada por Birch et al. (1999) na avaliação do crescimento de 5 cultivares de milho na Austrália.

Tabela 3. Teste de Tukey para médias de IAF $\left(\mathrm{m}^{2} \cdot \mathrm{m}^{-2}\right)$ e espessura de estratos $(\mathrm{cm})$ do dossel vertical de três híbridos de milho com diferentes arquiteturas de parte aérea:(A) estrato terço superior; (B) estrato terço médio; e (C) estrato terço inferior. Estádio de 12 folhas - 49 DAE

\begin{tabular}{cccccc}
\hline Estrato & BRS 1010 & BRS 3003 & BRS 1001 & DMS & CV \\
\hline A & $2,97 \mathrm{~A}^{1}$ & $2,99 \mathrm{~A}$ & $3,45 \mathrm{~A}$ & 0,64 & 10,4 \\
B & $1,62 \mathrm{~A}^{1}$ & $1,90 \mathrm{~A}$ & $1,81 \mathrm{~A}$ & 0,42 & 11,9 \\
C & $0,68 \mathrm{~A}^{1}$ & $0,72 \mathrm{~A}$ & $0,66 \mathrm{~A}$ & 0,14 & 10,1 \\
Total & $5,26 \mathrm{~A}^{1}$ & $5,61 \mathrm{~A}$ & $5,92 \mathrm{~A}$ & 1,12 & 10,2 \\
& & Espessura & & & \\
A,B,C & 63,8 & 67 & 64,6 & & \\
Total & 191,4 & 134 & 193,8 & & \\
\hline
\end{tabular}

${ }^{1}$ Médias seguidas pela mesma letra na linha não diferem estatisticamente entre si $(\mathrm{p} \leq 0,05)$

A estratificação do dossel em camadas teve como objetivo principal avaliar a contribuição de cada conjunto ("camada") de folhas na fotossíntese total da planta. A metodologia empregada partiu do princípio de que a radiação no dossel é atenuada a partir do ponto mais alto da planta, portanto, as "camadas" foram computadas como subdivisões do comprimento compreendido entre a lâmina foliar mais basal $\left(1^{\circ}\right.$ nó visível) até o topo do limbo foliar da folha mais nova na planta. O IAF estratificado por “camada" e a espessura das camadas são apresentados nas Tabelas 1 a 7. 
Tabela 4. Teste de Tukey para médias de IAF $\left(\mathrm{m}^{2} \cdot \mathrm{m}^{-2}\right)$ e espessura de estratos $(\mathrm{cm})$ do dossel vertical de três híbridos de milho com diferentes arquiteturas de parte aérea:(A) estrato terço superior; (B) estrato terço médio; e (C) estrato terço inferior. Estádio de florescimento - 64 DAE

\begin{tabular}{cccccc}
\hline Estrato & BRS 1010 & BRS 3003 & BRS 1001 & DMS & CV \\
\hline A & $2,10 \mathrm{AB}^{2}$ & $2,25 \mathrm{~A}$ & $2,03 \mathrm{~B}$ & 0,21 & 5,1 \\
B & $2,68 \mathrm{~A}^{1}$ & $2,79 \mathrm{~A}$ & $2,65 \mathrm{~A}$ & 0,37 & 7,0 \\
$\mathrm{C}$ & $1,19 \mathrm{~A}^{1}$ & $1,21 \mathrm{~A}$ & $1,39 \mathrm{~A}$ & 0,37 & 5,7 \\
Total & $5,97 \mathrm{~A}^{1}$ & $6,24 \mathrm{~A}$ & $6,06 \mathrm{~A}$ & 0,59 & 4,9 \\
& & Espessura & & & \\
A,B,C & 86 & 90 & 84 & & \\
Total & 258 & 270 & 252 & & \\
\hline
\end{tabular}

${ }^{1}$ Médias seguidas pela mesma letra na linha não diferem estatisticamente entre $\mathrm{si}(\mathrm{p} \leq 0,05)$

${ }^{2}$ Médias seguidas de letras diferentes diferem estatisticamente entre si $(p \leq 0,05)$

Uma análise geral dos resultados mostra uma dinâmica das proporções relativas no decorrer do ciclo da cultura, independente do genótipo observado. Tal dinâmica se verifica em função dos processos de emissão de novas folhas, expansão do limbo foliar e senescência.

No estádio de pendoamento do milho, as últimas folhas, incluindo a folha bandeira, são normalmente pequenas, verticais e espaçadas no colmo. Tal característica causou a diferença brusca da proporção relativa entre as camadas do terço superior, terço médio e terço inferior entre o estádio de 12 folhas e o estádio de florescimento. No estádio de 12 folhas, a proporção relativa das camadas na média dos genótipos foi de 55:32:13\%, e no estádio de florescimento essa média foi de 35:45:20\%. 
Tabela 5. Teste de Tukey para médias de IAF $\left(\mathrm{m}^{2} \cdot \mathrm{m}^{-2}\right)$ e espessura de estratos $(\mathrm{cm})$ do dossel vertical de três híbridos de milho com diferentes arquiteturas de parte aérea:(A) estrato terço superior; (B) estrato terço médio; e (C) estrato terço inferior. Estádio de grão leitoso - 80 DAE

\begin{tabular}{cccccc}
\hline Estrato & BRS 1010 & BRS 3003 & BRS 1001 & DMS & CV \\
\hline A & $2,69 \mathrm{~A}^{1}$ & $2,51 \mathrm{~A}$ & $2,98 \mathrm{~A}$ & 0,66 & 12,2 \\
B & $2,48 \mathrm{~A}^{1}$ & $2,79 \mathrm{~A}$ & $2,77 \mathrm{~A}$ & 0,70 & 13,2 \\
$\mathrm{C}$ & $0,78 \mathrm{~A}^{1}$ & $0,71 \mathrm{~A}$ & $0,69 \mathrm{~A}$ & 0,21 & 14,3 \\
Total & $5,95 \mathrm{~A}^{1}$ & $6,00 \mathrm{~A}$ & $6,44 \mathrm{~A}$ & 1,50 & 12,4 \\
& & Espessura & & & \\
A,B,C & 82 & 87 & 84 & & \\
Total & 246 & 261 & 252 & & \\
\hline
\end{tabular}

${ }^{1}$ Médias seguidas pela mesma letra na linha não diferem estatisticamente entre $\mathrm{si}(\mathrm{p} \leq 0,05)$

O período crítico para cultura do milho está em torno do florescimento. Nessa época as condições abióticas (água, temperatura e radiação) são de suma importância para a definição do potencial de produtivo da cultura. No estádio de florescimento, verifica-se uma proporção relativa entre as camadas do terço superior, terço médio e terço inferior muito semelhante entre os três genótipos, 33:44:23\%; 36:45:19\%; 35:45:20\%, para BRS 3003, BRS 1001e BRS 1010, respectivamente. A tentativa simplificada de se relacionar o desempenho da radiação no dossel baseada apenas nas proporções relativas da distribuição de folhas deve ser feita com cautela, pois a penetração da radiação no dossel depende entre outros fatores, como a distribuição das folhas nas camadas e os ângulos das superfícies foliares em relação ao ângulo de incidência dos raios solares. 
Tabela 6. Teste de Tukey para médias de IAF $\left(\mathrm{m}^{2} \cdot \mathrm{m}^{-2}\right)$ e espessura de estratos $(\mathrm{cm})$ do dossel vertical de três híbridos de milho com diferentes arquiteturas de parte aérea:(A) estrato terço superior; (B) estrato terço médio; e (C) estrato terço inferior. Estádio de grão pastoso - $100 \mathrm{DAE}$

\begin{tabular}{cccccc}
\hline Estrato & BRS 1010 & BRS 3003 & BRS 1001 & DMS & CV \\
\hline A & $2,47 \mathrm{~A}^{1}$ & IAF & & & \\
B & $2,44 \mathrm{~A}^{2}$ & $2,13 \mathrm{AB}$ & $2,59 \mathrm{~A}$ & 0,36 & 7,4 \\
Total & $4,91 \mathrm{~A}^{1}$ & $4,56 \mathrm{~A}$ & $4,37 \mathrm{~A}$ & 0,70 & 7,6 \\
& & Espessura & & & \\
A,B,C & 83 & 85 & 83 & \\
Total & 249 & 255 & 249 & \\
\hline
\end{tabular}

${ }^{1}$ Médias seguidas pela mesma letra na linha não diferem estatisticamente entre si $(p \leq 0,05)$

${ }^{2}$ Médias seguidas de letras diferentes diferem estatisticamente entre si $(p \leq 0,05)$

A partir do florescimento, já com o número máximo de folhas emitidas e com a paralisação da expansão foliar, observa-se a redução progressiva do IAF das folhas localizadas no terço inferior, chegando a zero no estádio de grão farináceo. No estádio de grão farináceo duro, apenas o terço superior ainda apresenta folhas. 
Tabela 7. Teste de Tukey para médias de IAF $\left(\mathrm{m}^{2} \cdot \mathrm{m}^{-2}\right)$ e espessura de estrato $(\mathrm{cm})$ do dossel vertical de três híbridos de milho com diferentes arquiteturas de parte aérea: (A) estrato terço superior. Estádio de grão farináceo duro - $114 \mathrm{DAE}$

\begin{tabular}{|c|c|c|c|c|c|}
\hline Estrato & BRS 1010 & BRS 3003 & BRS 1001 & DMS & $\mathrm{CV}(\%)$ \\
\hline \multirow{3}{*}{ A } & & IAF & & & \\
\hline & $2,28 \mathrm{~A}^{1}$ & $2,30 \mathrm{~A}$ & $1,69 \mathrm{~A}$ & 0,80 & 19,5 \\
\hline & & Espessura & & & \\
\hline $\mathrm{A}, \mathrm{B}, \mathrm{C}$ & 87 & 88,8 & 84,0 & & \\
\hline Total & 261 & 266,4 & 252 & & \\
\hline
\end{tabular}

${ }^{1}$ Médias seguidas pela mesma letra na linha não diferem estatisticamente entre $\mathrm{si}(\mathrm{p} \leq 0,05)$

De acordo com Boedhram et al. (2001), trabalhos de caracterização vertical de dosséis de milho devem ser feitos com intervalos de comprimento entre 20 e $30 \mathrm{~cm}$ com o objetivo de melhorar a precisão, e devem ser acompanhados de medidas fisiológicas e de interceptação da radiação visando o entendimento das inter-relações existentes.

\section{2 Área foliar específica}

A área foliar específica (área de folha por unidade de fitomassa seca de folha) é uma característica morfológica da planta, e que, para dada espécie, sofre modificação do valor em função das condições ambientais e da idade da cultura.

Os valores de AFE observados em 7 estádios fenológicos para os três híbridos avaliados, tanto para a planta inteira quanto para as camadas do dossel vertical são apresentados, juntamente com a estatística dos dados, na Tabela 8. A representação gráfica dos valores observados da AFE total de cada genótipo e em 7 estádios do ciclo são apresentados na Figura 5.

A Figura 5 mostra a AFE dos híbridos de milho decrescendo no decorrer do curso do período de crescimento, ou seja, a medida em que se evolui no ciclo, mais espessa vai se tornando a folha. Os valores observados da AFE foram reduzidos de $265 \mathrm{~cm}^{2} \cdot \mathrm{g}^{-1}$ na média do estádio de 4 folhas, para $145 \mathrm{~cm}^{2} \cdot \mathrm{g}^{-1}$, no estádio de grão 
farináceo duro. Os valores encontrados estão muito próximos dos obtidos por Danalatos et al. (1994) em duas regiões da Grécia de clima mediterrâneo.

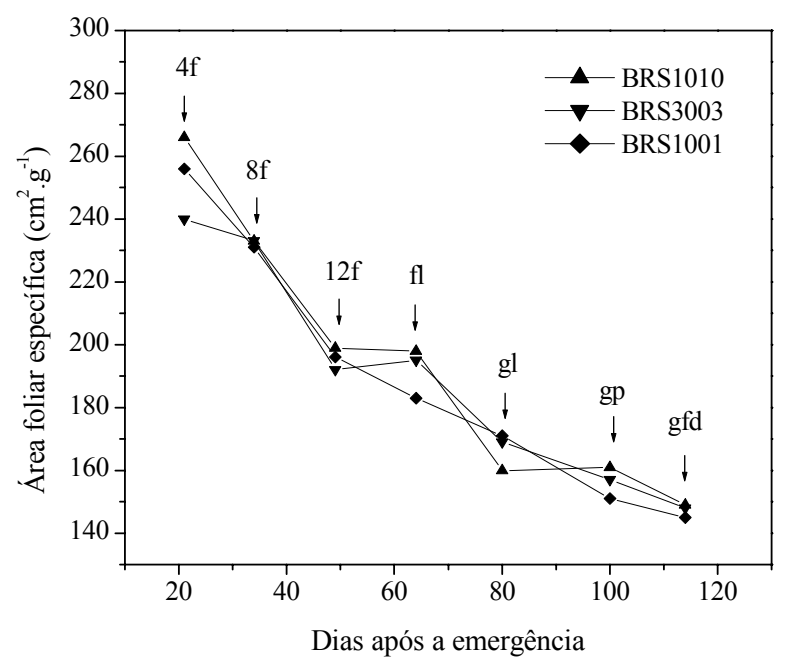

Figura 5 - Área foliar específica de três híbridos de milho da emergência ao estádio de grão farináceo duro

No estádio de quatro folhas desenroladas, aos 21 DAE, observamos uma razoável diferença, apesar de não significativa $(p \leq 0,05)$, entre os valores médios de AFE para os três híbridos. Tal diferença é semelhante à diferença observada para o IAF neste estádio e de acordo com o que já descrito naquele item da discussão, o híbrido BRS 3003 apresentou um arranque inicial superior aos dois outros. Com essa análise podemos especular que o híbrido BRS 3003, aos 21 DAE, apresenta um estádio de desenvolvimento relativo mais avançado que os demais.

Nos estádios de 8 e 12 folhas, observa-se uma similaridade grande entre os valores de AFE dos híbridos, tanto do total da planta quanto dos estratos. O período que se iniciou no estádio de 4 folhas e se encerrou no estádio de 12 folhas, corresponde a fase de crescimento exponencial da curva de crescimento biológico. As boas condições ambientais de temperatura, radiação, nutrientes e umidade do solo permitiram à cultura manifestar todo o seu potencial genético de crescimento. Durante este período altas taxas de crescimento relativo foliar são traduzidas em expansão foliar e no aumento da massa foliar por unidade de área foliar. Gmeling Meyling (1973) demonstrou que existe uma 
proporcionalidade inversa entre AFE e intensidade luminosa. Para esse autor, o aumento da espessura da folha e, portanto da diminuição da AFE, é um sintoma geral das altas intensidades luminosas e das altas taxas fotossintéticas que a cultura experimenta, que levam para uma fixação de carbono superior a taxa de translocação. $\mathrm{O}$ carboidrato não estrutural (amido e hexoses) "excedente" na folha é transformado em carboidrato estrutural (celulose e hemicelulose).

Observando os valores de AFE estratificado do estádio de 12 folhas (Tabela 8) nota-se que existem um padrão comum para os três híbridos estudados. As folhas do topo do dossel apresentam valores na ordem de $200 \mathrm{~cm}^{2} \cdot \mathrm{g}^{-1}$, as do meio de $180 \mathrm{~cm}^{2} \cdot \mathrm{g}^{-1} \mathrm{e}$ as da base do dossel da ordem de $210 \mathrm{~cm}^{2} \cdot \mathrm{g}^{-1}$. O padrão desta distribuição é determinado pela combinação de aspectos ontogênicos, fisiológicos e as suas inter-relações com o ambiente. As folhas basais são as que interceptam menor quantidade de luz, por conseguinte, apresentam pequenas taxas de fotossíntese. Na tentativa de interceptar mais luz estas folhas tendem a se expandir em área, levando a uma redução da espessura, portanto apresentam os mais altos valores de AFE. Neste estádio de 12 folhas, as folhas situadas no topo do dossel são consideras recém maduras, todo o carboidrato produzido anterior a esta fase foi direcionado para a expansão do limbo foliar e construção do aparato fotossintético, por isso ainda são delgadas, ou seja, apresentam um valor de AFE próximo ao do estrato basal. As taxas superiores de fotossíntese saturantes experimentadas pelas folhas desta camada (Tabela 20), e a exposição aos altos níveis de radiação favoreceram a o acúmulo de carboidrato, tal efeito é evidenciado no próximo estádio, florescimento, quando a diferença da AFE deste estrato praticamente se iguala ao valor de AFE do estrato médio. As folhas do estrato médio são as que apresentam o menor valor de AFE, portanto, são as folhas mais grossas. Neste estrato estão as folhas maduras do dossel, folhas que apresentam altas taxas fotossintéticas e que estiveram recebendo altos níveis de radiação. O engrossamento das folhas deste estrato também tem como causa a maior disponibilidade de fotoassimilados, provocado pela supremacia da taxa de assimilação de $\mathrm{CO}_{2}$ sobre a taxa de translocação. Isso acontece em condições ambientais ótimas de crescimento, como as ocorrido no experimento (Figura 7 e tabela 28). 
Tabela 8. Teste de Tukey para médias de AFE $\left(\mathrm{cm}^{2} \cdot \mathrm{g}^{-1}\right)$ de folhas do dossel vertical estratificado de três híbridos de milho com diferentes arquiteturas de parte aérea, do estádio de 4 folhas ao grão farináceo duro:(A) estrato terço superior; (B) estrato terço médio; e (C) estrato terço inferior

\begin{tabular}{|c|c|c|c|c|c|}
\hline Estrato & BRS 1010 & BRS 3003 & BRS 1001 & DMS & $\mathrm{CV}$ \\
\hline & & 4 folhas & & & \\
\hline \multirow[t]{2}{*}{ Total } & $266 A^{1}$ & $240 \mathrm{~A}$ & $256 \mathrm{~A}$ & 29 & 5,9 \\
\hline & & 8 folhas & & & \\
\hline A & $250 \mathrm{~A}^{1} \mathrm{a}^{4}$ & $237 \mathrm{Aa}^{4}$ & $232 \mathrm{Aa}^{2}$ & 30 & 6,3 \\
\hline B & $196 A^{1} b$ & $214 \mathrm{Ab}$ & $224 \mathrm{Aa}$ & 50 & 12,1 \\
\hline DMS & 41 & 20 & & & \\
\hline \multirow[t]{2}{*}{ Total } & $234 \mathrm{~A}^{1}$ & $233 \mathrm{~A}$ & $231 \mathrm{~A}$ & 24 & 5,3 \\
\hline & & 12 folhas & & & \\
\hline A & $208 \mathrm{~A}^{1} \mathrm{a}^{2}$ & $200 \mathrm{Aab}^{4}$ & $199 \mathrm{Aab}^{4}$ & 21 & 5,3 \\
\hline B & $182 A^{1} a$ & $179 \mathrm{Ab}$ & $185 \mathrm{Ab}$ & 30 & 8,4 \\
\hline $\mathrm{C}$ & $208 \mathrm{~A}^{1} \mathrm{a}$ & $204 \mathrm{Aa}$ & $218 \mathrm{Aa}$ & 36 & 8,6 \\
\hline DMS & 35 & 25 & 27 & & \\
\hline \multirow[t]{2}{*}{ Total } & $199 A^{1}$ & $192 \mathrm{~A}$ & $196 \mathrm{~A}$ & 22 & 5,8 \\
\hline & & florescimento & & & \\
\hline A & $194 A^{1} b^{4}$ & $191 \mathrm{Aab}^{4}$ & $181 \mathrm{Aa}^{2}$ & 25 & 6,7 \\
\hline B & $190 A^{1} b$ & $186 \mathrm{Ab}$ & 179Aa & 32 & 8,7 \\
\hline $\mathrm{C}$ & $229 A^{3} a$ & $228 \mathrm{ABa}$ & $195 \mathrm{Ba}$ & 34 & 7,9 \\
\hline DMS & 24 & 42 & 22 & & \\
\hline Total & $198 \mathrm{~A}^{1}$ & $195 \mathrm{~A}$ & $183 \mathrm{~A}$ & 27 & 7,2 \\
\hline
\end{tabular}

${ }^{1}$ Médias seguidas de mesma letra maiúscula na linha não diferem estatisticamente entre si $(\mathrm{p} \leq 0,05)$

${ }^{2}$ Médias seguidas de mesma letra minúscula na coluna não diferem estatisticamente entre si $(\mathrm{p} \leq 0,05)$

${ }^{3}$ Médias seguidas de letra maiúscula diferente na linha diferem estatisticamente entre si $(p \leq 0,05)$

${ }^{4}$ Médias seguidas de letra minúscula diferente na coluna diferem estatisticamente entre si $(\mathrm{p} \leq 0,05)$ 
Tabela 9. Teste de Tukey para médias de AFE $\left(\mathrm{cm}^{2} \cdot \mathrm{g}^{-1}\right)$ de folhas do dossel vertical estratificado de três híbridos de milho com diferentes arquiteturas de parte aérea, do estádio de grão leitoso ao grão farináceo duro:(A) estrato terço superior; (B) estrato terço médio; e (C) estrato terço inferior

\begin{tabular}{|c|c|c|c|c|c|}
\hline Estrato & BRS 1010 & BRS 3003 & BRS 1001 & DMS & $\mathrm{CV}$ \\
\hline \multicolumn{6}{|c|}{ grão leitoso } \\
\hline $\mathrm{A}$ & $164 \mathrm{~A}^{1} \mathrm{ab}^{4}$ & $161 \mathrm{Aba}^{4}$ & $164 \mathrm{Aa}^{2}$ & 15 & 4,7 \\
\hline $\mathrm{B}$ & $151 \mathrm{~B}^{3} \mathrm{~b}$ & $172 \mathrm{ABb}$ & $175 \mathrm{Aa}$ & 22 & 6,6 \\
\hline $\mathrm{C}$ & $176 A^{1} a$ & $189 \mathrm{Aa}$ & $188 \mathrm{Aa}$ & 36 & 9,9 \\
\hline DMS & 21 & 16 & 36 & & \\
\hline Total & $160 \mathrm{~A}^{1}$ & $169 \mathrm{~A}$ & $171 \mathrm{~A}$ & 16 & 5,0 \\
\hline \multicolumn{6}{|c|}{ grão pastoso } \\
\hline A & $155 \mathrm{~A}^{1} \mathrm{a}^{2}$ & $155 \mathrm{Aa}$ & $147 \mathrm{Ab}^{4}$ & 19 & 6,2 \\
\hline B & $167 \mathrm{~A}^{1} \mathrm{a}$ & $166 \mathrm{Aa}$ & $158 \mathrm{Aa}$ & 20 & 6,2 \\
\hline DMS & 16 & 24 & 11 & & \\
\hline Total & $161 \mathrm{~A}^{1}$ & $157 \mathrm{~A}$ & $151 \mathrm{~A}$ & 17 & 5,5 \\
\hline \multicolumn{6}{|c|}{ gr.far. duro } \\
\hline Total & $149 \mathrm{~A}^{1}$ & 148 & 145 & 15 & 5,1 \\
\hline
\end{tabular}

${ }^{1}$ Médias seguidas de mesma letra maiúscula na linha não diferem estatisticamente entre si $(\mathrm{p} \leq 0,05)$

${ }^{2}$ Médias seguidas de mesma letra minúscula na coluna não diferem estatisticamente entre si $(\mathrm{p} \leq 0,05)$

${ }^{3}$ Médias seguidas de letra maiúscula diferente na linha diferem estatisticamente entre si $(\mathrm{p} \leq 0,05)$

${ }^{4}$ Médias seguidas de letra minúscula diferente na coluna diferem estatisticamente entre si $(\mathrm{p} \leq 0,05)$

Chatterton et al. (1972) consideram a AFE como uma medida do balanço da produção de fotossintatos/translocação e que a mudança deste balanço pode refletir na produtividade potencial. O mesmo autor comenta que a deficiência em translocar rapidamente e utilizar os produtos da fotossíntese podem levar a redução do crescimento de muitas plantas.

No estádio de florescimento, podemos observa-se (Tabela 8) uma aproximação entre os valores de AFE do estrato superior e estrato médio, mostrando assim uma 
tendência de igualdade das condições fisiológicas da folha e dos níveis de radiação que chegam nos estratos. Vale destacar que a observação desse parâmetro (AFE) em determinado estádio fisiológico integra todas as variáveis que influenciaram o parâmetro até aquele momento.

O período entre o estádio de 12 folhas e o florescimento é marcado pelo desenvolvimento das estruturas reprodutivas do milho. O desenvolvimento destas estruturas representa o principal "dreno" para os fotoassimilados produzidos na folha. Neste período a cultura reduz a taxa de crescimento de cultura (Figura 6). A habilidade de alocar os fotoassimilados das "fontes" (folhas) para os drenos (regiões meristemáticas de desenvolvimento das estruturas reprodutivas) pode ser determinante na produtividade final da cultura. Segundo Rodrigues e Didonet (2003) o número potencial de óvulos (grãos) por espiga é determinado quando as plantas atingem 10 a 12 folhas com o colar visível, momento muito antes do espigamento. Da análise dos resultados de AFE para o estádio de florescimento dos três híbridos, contidos na Tabela 8 e na Figura 5, podemos verificar uma estabilização dos valores de AFE dos híbridos BRS 1010 e BRS 3003 e uma redução do valor de AFE para o híbrido BRS 1001. Tal resultado pode ser relacionado com a maior habilidade de alocação dos fotoassimilados, ou seja, uma melhor relação fonte dreno, para os dois primeiros e uma pior para o último, resultando em um espessamento maior da folha.

Existe um subperíodo dentro do período compreendido entre as fases de florescimento e grão leitoso que compreende uma fase denominada de fase "lag" do crescimento de grãos (Johnson \& Tanner, 1972; Tollenar, 1977), em que, o crescimento dos grãos recém diferenciados é muito lento. Para os três híbridos observa-se uma redução do valor médio de AFE, entretanto, a queda é mais pronunciada para os híbridos BRS 1010 e BRS 3003, os quais sofrem uma redução de 38 e $26 \mathrm{~cm}^{2} \cdot \mathrm{g}^{-1}$, respectivamente, no valor do AFE. Para o híbrido BRS 1010 a maior redução foi verificada nas folhas que compõem o estrato médio, o que indica que a arquitetura com folhas mais eretas pode estar favorecendo a penetração de luz até esta camada e, com isso, possibilitando maiores taxas de assimilação de $\mathrm{CO}_{2}$. A pequena força de dreno dos grãos no estádio iniciais que se encontram, o estabelecimento das vias de transporte 
entre as folhas e cada grão da espiga e as altas taxas de fotossíntese nesta época, favorecem a um "excedente" de carboidratos nas folhas e sua transformação em carboidratos estruturais, mesmo com uma alocação significativa em outros órgãos (Figura 6). O genótipo BRS 1001 que apresentou uma diminuição mais gradativa do seu valor de AFE no curso do ciclo, teve uma menor redução do valor de AFE, que pode ser justificado pelo equilíbrio entre a produção e o consumo dos fotoassimilados, já que é nesse período onde se obteve a maior taxa de crescimento de cultura (TCC) no ciclo (Figura 6). A redução do valor da AFE no estrato basal se deve a senescência das folhas mais velhas, mais sombreadas e mais delgadas, localizadas na base da camada.

No estádio de grão pastoso, os genótipos, com exceção do BRS 1010 que não variou, apresentaram uma redução dos valores de AFE médio para a planta. Observa-se na Tabela 9 que o estrato onde ocorreu a maior redução do valor foi o estrato superior, o qual intercepta os mais altos níveis de radiação e que se observam as maiores taxas de fotossíntese. A estabilização do valor de AFE no híbrido BRS 1010 associado ao elevado ganho de FSe, mostra que esse híbrido é eficiente na translocação de fotoassimilados da folha para os grãos.

No estádio de grão farináceo duro, os híbridos apresentaram valores semelhantes para AFE média da planta, com valor em torno de $147 \mathrm{~cm}^{2} \cdot \mathrm{g}^{-1}$. Este valor médio de AFE para o final do ciclo da cultura de milho e semelhante ao valor encontrado por Danalatos et al. (1994) em condições de clima mediterrâneo.

O uso da área foliar específica tem sido empregado em diversos modelos de crescimento de culturas em virtude da sua alta correlação com estádio de desenvolvimento, e sua independência das condições de solo, localização, população de plantas ou cultivar.

\subsection{Fitomassa seca da parte aérea de plantas, partição de fitomassa seca e produtividade de grãos}

A produção de fitomassa seca da parte aérea colhida (FSa) e a partição dessa entre os componentes: fitomassa de colmos (FSc), fitomassa seca total de folhas (FSf), fitomassa seca de folhas secas (FSfs) e fitomassa seca de espiga (FSe), determinada em 
7 estádios fenológicos da cultura ( 4 folhas, 8 folhas, 12 folhas, florescimento, grão leitoso, grão pastoso e grão farináceo duro), dos três híbridos avaliados são apresentados nas tabelas de 9 a 16 e na Figura 6, juntamente com as estatísticas.

O planejamento e a condução do experimento no campo foram feitos de tal forma que os híbridos avaliados pudessem manifestar todo o seu potencial genético, ou seja, tomaram-se os devidos cuidados quanto à definição da melhor época de plantio, o material genético, a origem das sementes, o preparo do solo, o tratamento de sementes, a adubação de plantio, a semeadura, a irrigação e o controle de pragas, doenças e plantas daninhas.

As produtividades finais de fitomassa seca da parte aérea e de grãos indicam que os materiais estiveram próximos do potencial produtivo para as condições do clima de Piracicaba-SP, dessa forma os dados aqui apresentados refletem as características que um agricultor deve esperar quando adotar um dos híbridos, e manejar a sua lavoura para alta produtividade.

Na Figura 6, podemos observar que até o estádio de 8 folhas (34 DAE) a cultura acumulou em torno de $6 \%$ do total produzido no estádio de grão farináceo duro (última coleta de plantas). É pouco se considerarmos que neste momento já foram transcorridos mais de $25 \%$ do total de dias do ciclo da cultura. Apesar da fitomassa acumulada ser pequena, é nesse período que a cultura apresenta as maiores taxas de crescimento relativo (TCR), que indica o ganho de fitomassa seca nova em relação a fitomassa préexistente. 


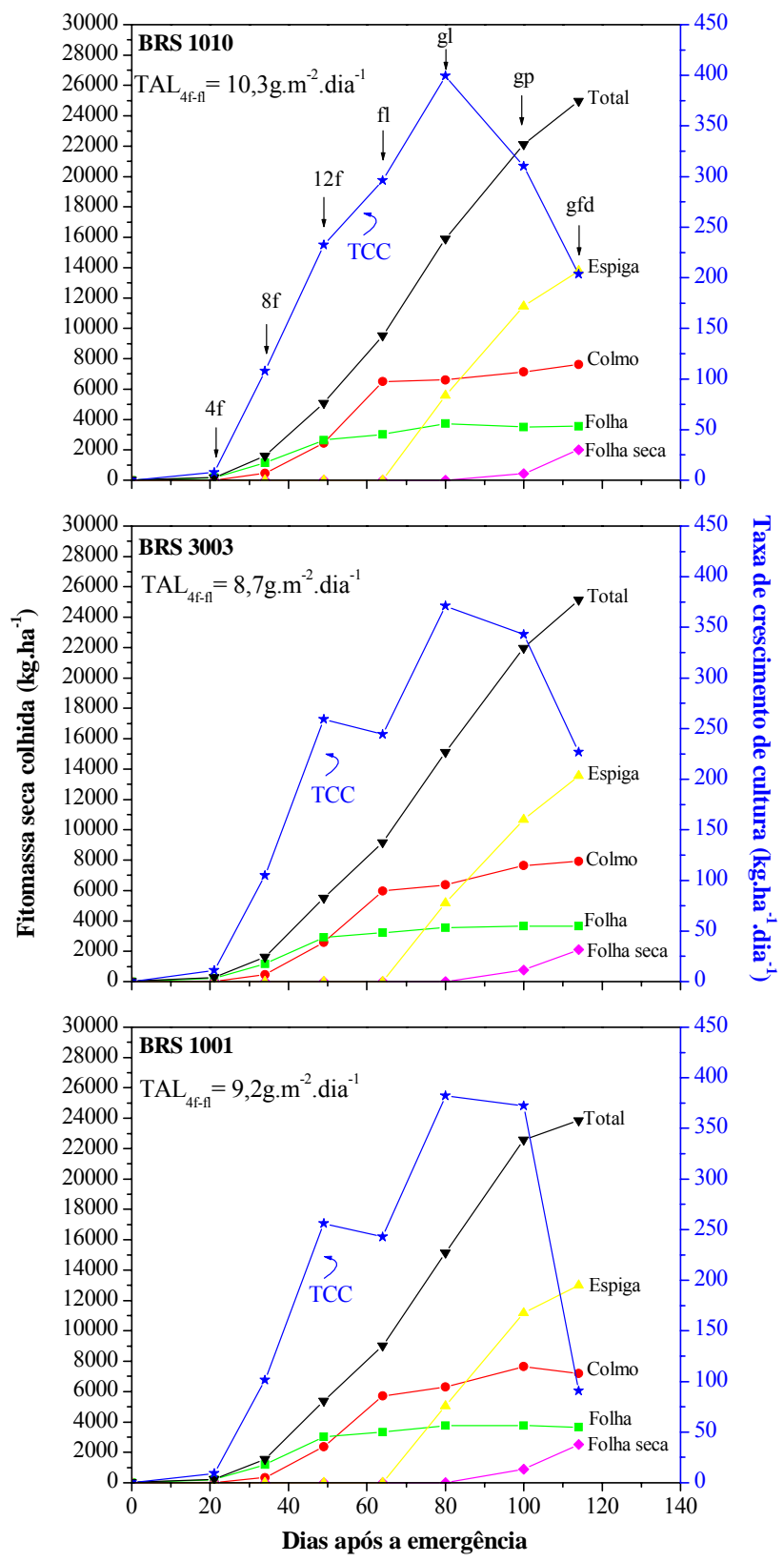

Figura 6 - Fitomassa seca de parte aérea (total), fitomassa seca de colmo, fitomassa seca de folhas, fitomassa seca de folha seca, fitomassa seca de espiga, taxa de crescimento da cultura (TCC) e taxa assimilatória líquida (TAL) de três híbridos de milho, da emergência ao estádio de grão farináceo duro 
No estádio de 4 folhas, o híbrido BRS 3003 apresenta as maiores FSc, FSf e FSa expressas em kg.ha ${ }^{-1}$ em relação aos demais, sendo que uma diferença significativa com nível de probabilidade de 5\% é encontrada entre a FSa deste em relação ao BRS 1010. Tal diferença foi visível no campo, e está relacionada com a maior quantidade de reserva contida na semente no híbrido BRS 3003, que permitiu um arranque inicial mais rápido, e que é confirmado pela maior taxa de crescimento de cultura (TCC) deste híbrido, 11,07, contra 7,72 do híbrido BRS 1010 e 9,00kg.ha ${ }^{-1} \cdot$ dia $^{-1}$ do BRS 1001. Mas ao compararmos a taxa de crescimento relativo, expressa em $\mathrm{kg}$ de matéria de seca produzida por $\mathrm{kg}$ de matéria seca pré-existente por dia $\left(\mathrm{kg} \cdot \mathrm{kg}^{-1} \cdot \mathrm{dia}^{-1}\right)$, não se observa diferença entre estes dois híbridos, com valores de 0,0949 e 0,0947 para os híbridos BRS 1010 e BRS 3003, respectivamente. A TCR do híbrido BRS 1001 foi de $0,863 \mathrm{~kg} \cdot \mathrm{kg}^{-1} \cdot \mathrm{dia}^{-1}$.

A relação $\mathrm{FSf} / \mathrm{FSa}$ nos primeiros estádios de crescimento é muito alta, com as folhas representando no estádio 4 folhas cerca de $90 \%$ da FSa. Neste, estádio o maior investimento está na formação de raízes, que não foi avaliado neste estudo.

Tabela 10. Teste de Tukey para médias de FSc, FSf, e FSa (kg.ha-1) de três híbridos de milho com diferentes arquiteturas de parte aérea. Estádio de 4 folhas $21 \mathrm{DAE}$

\begin{tabular}{cccc}
\hline Híbrido & FSc & FSf & FSa \\
\hline BRS 1010 & $12,2 \mathrm{~A}^{1}$ & $175,5 \mathrm{~A}^{1}$ & $187,7 \mathrm{~B}^{2}$ \\
BRS 3003 & $32,0 \mathrm{~A}$ & $237,4^{\mathrm{A}}$ & $269,4 \mathrm{~A}$ \\
BRS 1001 & $29,4 \mathrm{~A}$ & $196,6^{\mathrm{A}}$ & $226,0 \mathrm{AB}$ \\
DMS & 48,4 & 82,6 & 72,0 \\
CV & 97,0 & 20,6 & 16,0 \\
\hline
\end{tabular}

${ }^{1}$ Médias seguidas de mesma letra não diferem estatisticamente entre si $(\mathrm{p} \leq 0,05)$

${ }^{2}$ Médias seguidas de letras diferentes diferem estatisticamente entre si $(\mathrm{p} \leq 0,05)$

No estádio de 8 folhas já não ocorrem mais diferenças significativas entre os híbridos quanto as produtividades de fitomassa seca. A maior TCR do híbrido BRS 1010 
em relação aos demais no período entre os estádios de 4 e 8 folhas reflete a sua maior eficiência no uso dos recursos para o crescimento. Os valores de TCR para o período foram: 0,$1644 ; 0,1385 ; 0,1477 \mathrm{~kg} \cdot \mathrm{kg}^{-1} \cdot \mathrm{dia}^{-1}$, para os híbridos BRS 1010, 3003 e 1001, respectivamente. Neste estádio já se observa uma tendência do híbrido $1001 \mathrm{em}$ direcionar os fotoassimilados produzidos para a expansão da lâmina foliar. A relações FSf/FSa para os três híbridos foram: 0,72; 0,72 e 0,74, para os híbridos BRS 1010, 3003 e 1001.

Tabela 11. Teste de Tukey para médias de FSc, FSf, e Fsa, $\left(\mathrm{kg}_{\mathrm{k}} \mathrm{ha}^{-1}\right)$, de três híbridos de milho com diferentes arquiteturas de parte aérea. Estádio de 8 folhas 34 DAE

\begin{tabular}{cccc}
\hline Híbrido & FSc & FSf & FSa \\
\hline BRS 1010 & $451,7 \mathrm{~A}^{1}$ & $1138,9 \mathrm{~A}^{1}$ & $1590,6 \mathrm{~A}^{1}$ \\
BRS 3003 & $455,5 \mathrm{~A}$ & $1176,2^{\mathrm{A}}$ & $1631,7 \mathrm{~A}$ \\
BRS 1001 & $400,7 \mathrm{~A}$ & $1142,0^{\mathrm{A}}$ & $1542,7 \mathrm{~A}$ \\
DMS & 204,9 & 212,2 & 377,2 \\
CV(\%) & 23,8 & 9,3 & 12,0 \\
\hline
\end{tabular}

${ }^{1}$ Médias seguidas pela mesma letra não diferem estatisticamente entre si $(\mathrm{p} \leq 0,05)$

$\mathrm{Na}$ amostragem do estádio de 12 folhas (49 DAE), um incremento mais expressivo na TCC dos híbridos BRS 3003 e 1001 em relação ao híbrido BRS 1010 pode ser observado na Figura 6. Tal comportamento do BRS 1010 é sustentado também pelas suas menores taxas de crescimento relativo e taxa assimilatória líquida (TAL) para o período entre 8 a 12 folhas. Os valores de TCR para o período foram: 0,0773, 0,0812 e $0,0833 \mathrm{~kg} \cdot \mathrm{kg}^{-1} \cdot \mathrm{dia}^{-1}$ para os híbridos BRS 1010, 3003 e 1001, respectivamente. Os valores de TAL para o período foram: 5,97, 6,48 e 6,18g.m ${ }^{-2} \cdot \mathrm{dia}^{-1}$ para os híbridos BRS 1010, BRS 3003 e BRS 1001, respectivamente.

É no estádio de 12 folhas que a FSc e a FSf apresentam praticamente a mesma contribuição, 50\% cada uma, para a produtividade de FSa. A relação FSf/FSa do híbrido BRS 1001 é superior a dos demais, mostrando uma nítida estratégia diferenciada de 
crescimento. A relação FSf/FSa para os híbridos foram: 0,52, 0,52 e 0,56 para BRS 1010, 3003 e 1001, respectivamente. Na Tabela 12 observa-se uma diferença significativa $(\mathrm{p} \leq 0,05)$ para FSf entre o BRS 1001 e 1010, reforçando a idéia de exploração diferenciada do ambiente.

Tabela 12. Teste de Tukey para médias de FSc, FSf, e FSa (kg.ha-1) de três híbridos de milho com diferentes arquiteturas de parte aérea. Estádio de 12 folhas - (49 DAE)

\begin{tabular}{cccc}
\hline Híbridos & FSc & FSf & FSa \\
\hline BRS 1010 & $2443,8 \mathrm{~A}^{1}$ & $2631,7 \mathrm{~B}^{2}$ & $5075,5 \mathrm{~A}^{1}$ \\
BRS 3003 & $2599,2 \mathrm{~A}$ & $2916,3 \mathrm{AB}$ & $5515,5 \mathrm{~A}$ \\
BRS 1001 & $2365,6 \mathrm{~A}$ & $3020,6^{\mathrm{A}}$ & $5386,2 \mathrm{~A}$ \\
DMS & 322,1 & 386,7 & 612,9 \\
CV(\%) & 6,6 & 6,9 & 5,8 \\
\hline
\end{tabular}

${ }^{1}$ Médias seguidas pela mesma letra na linha não diferem estatisticamente entre si $(\mathrm{p} \leq 0,05)$

${ }^{2}$ Médias seguidas de letras diferentes diferem estatisticamente entre si $(\mathrm{p} \leq 0,05)$

Na Figura 6 podemos observar que, dentre os híbridos, o BRS 1010 apresenta a menor queda na TCC no período de 12 folhas ao florescimento (Figura 6). A queda na TCC é muito semelhante nos genótipos BRS 1001 e 3003, no entanto, para o BRS 1001 a queda foi mais sentida no ganho de FSf, e no genótipo BR 3003 tanto folha quanto colmo tiveram suas taxas de acúmulo proporcionalmente reduzidas. O genótipo BRS 1010 apresentou neste período um expressivo ganho na FSc (Figura 6e Tabelas 10 e 11), superando os demais híbridos em $800 \mathrm{~kg} \cdot \mathrm{ha}^{-1}$.

A TCR neste período também foi superior no BRS 1010, indicando a sua eficiência na conversão de fotoassimilados em massa, os valores calculados de TCR para o período foram: 0,$0419 ; 0,0339$ e $0,0344 \mathrm{~kg} \cdot \mathrm{kg}^{-1} \cdot \mathrm{dia}^{-1}$, para os híbridos BRS 1010, BRS 3003 e BRS 1001, respectivamente.

Essa fase (de 12 folhas ao florescimento) é marcada pelo término da emissão de novas folhas e pelo desenvolvimento das estruturas reprodutiva masculina e feminina. $\mathrm{O}$ 
desenvolvimento destas estruturas consome uma boa parte dos carboidratos produzidos pela fotossíntese corrente e provavelmente de carboidratos do "pool" de reservas. A habilidade de translocar e alocar recurso para este processo e ainda manter o ganho de fitomassa, passa pela disponibilidade de fotoassimilados proveniente da fotossíntese corrente e pela capacidade de alocar estes carboidratos para os colmos, já que a emissão de novas folhas praticamente se encerrou.

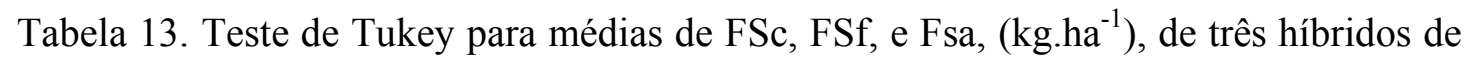
milho com diferentes arquiteturas de parte aérea. Estádio de florescimento $64 \mathrm{DAE}$

\begin{tabular}{cccc}
\hline Híbridos & FSc & FSf & FSa \\
\hline BRS 1010 & $6500,6 \mathrm{~A}^{1}$ & $3018,1 \mathrm{~A}^{1}$ & $9518,7 \mathrm{~A}^{1}$ \\
BRS 3003 & $5962,9 \mathrm{~A}$ & $3215,2^{\mathrm{A}}$ & $9178,1 \mathrm{~A}$ \\
BRS 1001 & $5704,4 \mathrm{~A}$ & $3321,3^{\mathrm{A}}$ & $9025,7 \mathrm{~A}$ \\
DMS & 13,10 & 352,5 & 1560,7 \\
CV(\%) & 10,9 & 5,6 & 8,5 \\
\hline
\end{tabular}

${ }^{1}$ Médias seguidas de mesma letra não diferem estatisticamente entre si $(\mathrm{p} \leq 0,05)$

A taxa assimilatória líquida é um parâmetro de crescimento que representa o incremento de fitomassa por unidade de área foliar durante um determinado tempo, normalmente de um dia. Ela difere da taxa fotossintética líquida por computar todo o balanço de um dia, e não apenas do período luminoso. Podemos observar na Figura 6 os valores relativos a TAL calculada para o período entre os estádios de 4 folhas e florescimento. O BRS 1010 apresenta o maior valor, seguido pelo BRS 1001 e por último está o BRS 3003. Esse resultado mostra que o BRS 1010, para esse período, foi superior no saldo do balanço entre fotossíntese e respiração. 
Tabela 14. Teste de Tukey para médias de FSc, FSf, FSfs, FSe, Fsa, $\left(\mathrm{kg} \mathrm{ha}^{-1}\right)$, e relação FSe/FSa de três híbridos de milho com diferentes arquiteturas de parte aérea. Estádio de grão leitoso - 80 DAE

\begin{tabular}{cccccc}
\hline Híbridos & FSc & FSf & FSe & FSa & FSe/FSa \\
\hline BRS 1010 & $6597,2 \mathrm{~A}^{1}$ & $3729,8 \mathrm{~A}^{1}$ & $5580,5 \mathrm{~A}^{1}$ & $15907,5 \mathrm{~A}^{1}$ & $0,35 \mathrm{~A}^{1}$ \\
BRS 3003 & $6380,2 \mathrm{~A}$ & $3553,8 \mathrm{~A}$ & $5185,1 \mathrm{~A}$ & $15119,1 \mathrm{~A}$ & $0,34 \mathrm{~A}$ \\
BRS 1001 & $6305,0 \mathrm{~A}$ & $3771,0 \mathrm{~A}$ & $5066,9 \mathrm{~A}$ & $15142,9 \mathrm{~A}$ & $0,33 \mathrm{~A}$ \\
DMS & 737,6 & 737,6 & 913,6 & 1763,3 & 0,03 \\
CV & 5,1 & 10,1 & 8,8 & 5,8 & 5,0 \\
\hline
\end{tabular}

${ }^{1}$ Médias seguidas de mesma letra na não diferem estatisticamente entre si $(\mathrm{p} \leq 0,05)$

Com o surgimento da espiga, a TCC volta a incrementar e é no período entre os estádios de florescimento e grão leitoso que são registrados os maiores valores para esse parâmetro de crescimento. O BRS 1010 acumula 399,3kg.ha ${ }^{-1} \cdot$ dia $^{-1}$, o 3003 acumula $371,3 \mathrm{~kg} \cdot \mathrm{ha}^{-1} \cdot \mathrm{dia}^{-1}$ e o BRS 1001 acumula $382,3 \mathrm{~kg} \cdot \mathrm{ha}^{-1} \cdot \mathrm{dia}^{-1}$.

O BRS 1010 além de apresentar maior TCC, também destina mais fotoassimilados para o crescimento das espigas, verificado pela maior relação $\mathrm{FSe} / \mathrm{FSa}$ (Figura 6). Nesse híbrido a FSc se manteve estabilizada enquanto a FSf apresentou o maior incremento entre os híbridos, mesmo que pouco significativo.

É no estádio de grão leitoso que se verifica a maior FSf de todo o ciclo, acompanhando o índice de área foliar (Tabela 14). Até este estádio a senescência de folhas não foi detectada de forma expressiva, mostrando que o enchimento dos grãos da espiga foram as expensas dos produtos da fotossíntese corrente.

Na Figura 6 se observa que a TCC, do período entre o estádio de grão leitoso e grão pastoso sofre queda para os três híbridos, no entanto, o híbrido BRS 1010 é o que sofre a maior redução. Mas como pode ser verificado na Tabela 14 este híbrido aumenta a sua destinação de fotoassimilados para o crescimento da espiga em relação aos demais. Uma diferença significativa $(\mathrm{p} \leq 0,05)$ na relação $\mathrm{FSe} / \mathrm{FSa}$ ocorre entre o BRS 1010 e o BRS 3003. 
A FSe acumulada entre os estádios de grão leitoso e grão pastoso para os híbridos BRS 1010, 3003 e 1001 foram respectivamente de: 5886,0; 5494,9 e 6100,3kg.ha ${ }^{-1}$. Denota-se que o BRS 1001 foi superior no incremento da FSe neste período em relação aos demais. A fitomassa seca de folha seca deste último híbrido citado foi superior a obtida pelos demais (Figura 6 e Tabela 15), com diferença de $300 \mathrm{~kg} \cdot \mathrm{ha}^{-1}$, que foi significativa $(\mathrm{p} \leq 0,05)$ para o BRS 1001. Esses resultados apontam que o crescimento das espigas do híbrido BRS 1001 contou com uma contribuição de carboidratos oriundo do desdobramento de estruturas e remobilização de reservas das folhas senescentes, além do fotoassimilados da fotossíntese corrente em folhas ativas.

O estádio de grão farináceo duro (114 DAE) foi o último estágio que se analisou o crescimento, acúmulo e partição de fitomassa dos híbridos estudados.

Tabela 15. Teste de Tukey para médias de FSc, FSf, FSfs, FSe, Fsa, em kg.ha-1 ${ }^{-1}$ e relação $\mathrm{FSe} / \mathrm{FSa}$ de três híbridos de milho com diferentes arquiteturas de parte aérea. Estádio de grão pastoso - 100 DAE

\begin{tabular}{ccccccc}
\hline Híbrido & FSc & FSf & FSfs & FSe & FSa & FSe/FSa \\
\hline BRS 1010 & $7142,9 \mathrm{~A}^{1}$ & $3503,8 \mathrm{~A}^{1}$ & $443,5 \mathrm{~B}^{2}$ & $11466,5 \mathrm{~A}^{1}$ & $22113,2 \mathrm{~A}^{1}$ & $0,52 \mathrm{~A}^{2}$ \\
BRS 3003 & $7641,3 \mathrm{~A}$ & $3656,7 \mathrm{~A}$ & $754,6 \mathrm{AB}$ & $10681,0 \mathrm{~A}$ & $21979,0 \mathrm{~A}$ & $0,48 \mathrm{~B}$ \\
BRS 1001 & $7649,6 \mathrm{~A}$ & $3769,5 \mathrm{~A}$ & $878,1 \mathrm{~A}$ & $11167,2 \mathrm{~A}$ & $22586,3 \mathrm{~A}$ & $0,49 \mathrm{AB}$ \\
DMS & 851,7 & 340,5 & 361,8 & 1752,8 & 3375,8 & 0,03 \\
CV(\%) & 11,4 & 4,7 & 26,5 & 8,00 & 7,7 & 2,7 \\
\hline
\end{tabular}

${ }^{1}$ Médias seguidas pela mesma letra na linha não diferem estatisticamente entre si $(\mathrm{p} \leq 0,05)$

${ }^{2}$ Médias seguidas de letras diferentes diferem estatisticamente entre si $(\mathrm{p} \leq 0,05)$

O período entre os estádios de grão pastoso e grão farináceo duro é marcado pelas maiores diferenças entre os genótipos durante todo o ciclo, provavelmente pela proximidade do fechamento do ciclo. Durante o processo de senescência outros mecanismos fisiológicos começam atuar, fazendo desta fase totalmente distinta das fases do crescimento vegetativo e do período inicial de enchimento de grãos. A habilidade em retardar a senescência de folhas, manutenção das taxas fotossintéticas em níveis 
elevados e a capacidade de remobilizar nutrientes e carboidratos, pode ser fundamental para garantir uma superioridade final, no que tange a produtividade de grãos.

No estudo em questão, com objetivo de padronizar as medidas, foi adotado uma população de 66.000 plantas.ha $^{-1}$ para os três híbridos. O híbrido BRS 1001 é recomendado na população de 50.000 plantas.ha', e na sua caracterização e nas avaliações de campo é considerado o mais tardio entre os três híbridos estudados. Entretanto, no estudo, foi o primeiro híbrido a desencadear o processo de senescência. A suas características de arquitetura mais plana e o seu alto índice de área foliar podem ter levado ao estado de ponto de compensação lumínico das folhas inferiores do dossel. No estádio de grão farináceo duro ele apresentou a FSFs superior aos demais e com diferença significativa para o BRS 1010 (Tabela 16 e Figura 6). Ele teve uma queda vertiginosa na TCC, e também foi o que menos acumulou FSe entre os estádios de grão pastoso e grão farináceo duro, apenas $1846,3 \mathrm{~kg} \cdot \mathrm{ha}^{-1}$, contra $2322,7 \mathrm{~kg} \cdot \mathrm{ha}^{-1}$ do híbrido BRS 1010 e 2882,0kg.ha- ${ }^{-1}$ do híbrido BRS 3003. Permitindo a ocorrência de diferença significativa de FSe do estádio de grão farináceo duro entre ele (BRS 1001) e o BRS 1010, com erro de probabilidade de $5 \%$.

Tabela 16. Teste de Tukey para médias de FSc, FSf, FSfs, FSe, Fsa, $\left(\mathrm{kg} . \mathrm{ha}^{-1}\right)$, e relação FSe/FSa de três híbridos de milho com diferentes arquiteturas de parte aérea. Estádio de grão farináceo duro - 114 DAE

\begin{tabular}{ccccccc}
\hline Híbrido & FSc & FSf & FSfs & FSe & FSa & FSe/FSa \\
\hline BRS 1010 & $7628,3 \mathrm{~A}^{1}$ & $3544,0 \mathrm{~A}^{1}$ & $2013,8 \mathrm{~B}^{2}$ & $13789,2 \mathrm{~A}^{2}$ & $24961,5 \mathrm{~A}^{1}$ & $0,55 \mathrm{~A}^{1}$ \\
BRS 3003 & $7926,3 \mathrm{~A}$ & $3661,2 \mathrm{~A}$ & $2100,7 \mathrm{AB}$ & $13563,0 \mathrm{AB}$ & $25150,5 \mathrm{~A}$ & $0,54 \mathrm{~A}$ \\
BRS 1001 & $7177,1 \mathrm{~A}$ & $3664,0 \mathrm{~A}$ & $2502,9 \mathrm{~A}$ & $13013,5 \mathrm{~B}$ & $23854,6 \mathrm{~A}$ & $0,54 \mathrm{~A}$ \\
DMS & 906,7 & 245,6 & 468,1 & 1455,8 & 2205,2 & 0,02 \\
CV(\%) & 6,1 & 3,4 & 10,7 & 5,5 & 4,5 & 1,9
\end{tabular}

${ }^{1}$ Médias seguidas pela mesma letra na linha não diferem estatisticamente entre si $(\mathrm{p} \leq 0,05)$

${ }^{2}$ Médias seguidas de letras diferentes diferem estatisticamente entre si $(p \leq 0,05)$ 
O BRS 3003 é o que apresentou melhor desempenho neste último período de avaliação, superando a produtividade de FSa ao BRS 1010, mostrando uma habilidade maior em lidar com os processos de senescência. No entanto, o BRS 1010 mantém as maiores produtividades de FSe e relação $\mathrm{FSe} / \mathrm{FSa}$, apesar de não serem estatisticamente significativas as diferenças.

No estádio de grão farináceo duro o BRS 1001 reduz a FSc em relação ao estádio de grão pastoso, esta perda também foi verificada por Birch et al. (1999) em 4 dos 5 híbridos que avaliou. Segundo estes autores, queda foi relacionada com a translocação de reservas do colmo para o enchimento de grãos da espiga.

A produtividade final do experimento foi determinada no ponto de maturidade fisiológico que se deu aos 127 DAE. A visualização da camada preta foi o parâmetro para se determinar o ponto. A visualização da camada preta foi mais nítida em alguns genótipos e menos em outros, mas com o intuito de unificar os tratamentos foram todos colhidos na mesma data.

Os valores obtidos para produtividade de grãos estão apresentados na Tabela 17. O híbrido BRS 1010 foi superior em produtividade aos demais híbridos no Teste-T de comparação de médias. A diferença significativa para o BRS 1001 foi dada com um nível de probabilidade de 1\% e para o BRS 3003 de 5\%. O BRS 3003 também diferiu do BRS 1001 com um nível de $5 \%$ adotado.

Estes resultados indicam que o híbrido BRS 1010 de arquitetura de parte aérea caracterizada por apresentar folhas mais eretas foi superior na eficiência de transformar os recursos disponíveis no ambiente em massa de grãos. Considerando que a maior diferença entre os híbridos estudados é a arquitetura de parte aérea, a maneira de como essa radiação é atenuada nos vários estratos do dossel possibilitaram uma taxa fotossintética global superior e principalmente uma melhoria das relações fonte-dreno do híbrido BRS 1010. 
Tabela 17. Teste-t para médias de Pgr $\left(\mathrm{kg} \cdot \mathrm{ha}^{-1}\right)$ de três híbridos de milho com diferentes arquiteturas de parte aérea. Estádio de ponto de maturidade fisiológico - 127 DAE

\begin{tabular}{cc}
\hline Híbrido & Pgr \\
\hline BRS 1010 & $11323,1 \mathrm{~A}^{1} \mathrm{a}^{2}$ \\
BRS 3003 & $10725,2 \mathrm{Ba}$ \\
BRS 1001 & $9991,48 \mathrm{Cb}$ \\
CV $(\%)$ & 6,7 \\
\hline
\end{tabular}

${ }^{1}$ Médias seguidas de letra maiúscula diferente diferem estatisticamente entre si $(p \leq 0,05)$

${ }^{2}$ Médias seguidas de letra minúscula diferente diferem estatisticamente entre si $(\mathrm{p} \leq 0,01)$

\subsection{Assimilação máxima de $\mathrm{CO}_{2}$, respiração e eficiência quântica}

A contabilização da fotossíntese do dossel de uma cultura é tratada de forma mais mecanística em alguns modelos de crescimento de culturas. Normalmente esses modelos adotam parâmetros fisiológicos e físicos para a integração da fotossíntese no dossel. Parâmetros como a assimilação máxima bruta de $\mathrm{CO}_{2}\left(\mathrm{~A}_{\mathrm{m}}\right)$, eficiência quântica da fotossíntese (E), intensidade de radiação PAR (I), coeficiente de extinção (k) e o índice de área foliar (IAF) são normalmente empregados nesses modelos.

A obtenção destes parâmetros fisiológicos em medidas de campo é crucial para que um modelo estime com certa precisão este processo complexo e básico para o crescimento de uma cultura.

Dada as dificuldades de operação no campo, as peculiaridades do equipamento, as condições climáticas, e as características da cultura como porte alto e adensamento, as medidas se tornaram inviáveis a partir do estádio de 12 folhas. Os dados do estádio de grão leitoso se referem a uma única planta.

Das Tabelas 16 a 19 são apresentados dados médios para $A_{m}, \varepsilon$, e respiração de escuro obtidos de medidas no campo dos híbridos BRS 1010, BRS 3003 e BRS 1001, nos estádios fenológicos de 4 folhas, 8 folhas, 12 folhas e grão leitoso (respiração e $\varepsilon$ ). 
Os valores encontrados estão de acordo com diversos trabalhos que tratam de avaliar estes parâmetros fisiológicos na cultura do milho e adotado em modelos de crescimento (Thiagarajah et al., 1981; Ehleringer \& Pearcy, 1983; Dwyer \& Stewart, 1986; Dwyer et. al., 1989; Pateey et al., 1991; Yang et al., 2004; Tollenaar et al., 2004 e Ahmadzadeh, 2004). Os parâmetros estão expressos em unidades normalmente empregada em modelos de crescimento.

Tabela 18. Médias de $A_{m}\left(g \cdot m^{-2} \cdot h^{-1}\right.$ de $\left.C_{2}\right)$, respiração foliar de escuro $\left(g \cdot m^{-2} \cdot h^{-1}\right.$ de $\left.\mathrm{CO}_{2}\right)$ e $\varepsilon\left(\right.$ g. $\mathrm{MJ}^{-1}$ de $\left.\mathrm{CO}_{2}\right)$ de três híbridos de milho com diferentes arquiteturas de parte aérea. Estádio de 4 folhas - 21 DAE

\begin{tabular}{cccc}
\hline Híbrido & $\mathrm{A}_{\mathrm{m}}$ & Respiração & $\varepsilon$ \\
\hline BRS 1010 & 4,80 & 0,49 & 8,86 \\
BRS 3003 & 4,87 & 0,66 & 9,97 \\
BRS 1001 & 4,87 & 0,57 & 9,79 \\
\hline
\end{tabular}

Para todos os estádios fenológicos avaliados não ocorreram diferenças significativas na comparação das médias dos híbridos para valores de $\mathrm{A}_{\mathrm{m}}, \varepsilon$ e respiração de escuro (contraste de letra não apresentado), apesar de observamos de uma maneira geral a tendência para maiores valores de $\mathrm{A}_{\mathrm{m}}$ para o híbrido BRS 1010 .

Em uma análise conjunto dos híbridos podemos observar uma evolução da $A_{m}$ medida na folha recém madura, que correspondeu a folha analisada no estádio de 4 folhas, e as referentes ao do estrato superior nas análises feitas nos estádios de 8 e 12 folhas.

A folha analisada no estádio de $4 \mathrm{fl}$ vai se tornar parte do estrato médio inferior e do terço médio inferior quando a planta atingir os estádios de $8 \mathrm{fl}$ e $12 \mathrm{fl}$, respectivamente. De acordo com o apresentado nas Tabelas 16 a 18 existe uma manutenção da $\mathrm{A}_{\mathrm{m}}$ desta folha em torno de 4,80 (g.m $\mathrm{m}^{-2} \cdot \mathrm{h}^{-1}$ de $\left.\mathrm{CO}_{2}\right)$. O mesmo ocorrendo com a folha que foi analisada no estrato médio superior no estádio de $8 \mathrm{f}$ e que no estádio de $12 \mathrm{fl}$ foi analisado no terço inferior do dossel, com uma manutenção da $\mathrm{A}_{\mathrm{m}}$ em torno de $5,80 \mathrm{~g} \cdot \mathrm{m}^{-2} \cdot \mathrm{h}^{-1}$ de $\mathrm{CO}_{2}$. 
Essa mesma característica não é observada na $\varepsilon$, que se altera a medida em que vai ocupando estratos diferenciados na planta.

Esses resultados indicam que o estabelecimento do potencial máximo de assimilação de $\mathrm{CO}_{2}$ é definido quando a folha se torna madura, não sendo alterado ou muito pouco com a evolução da idade da folha. Já a $\varepsilon$ é mutável de acordo com as condições do ambiente, ou seja, o aparato fotossintético se ajusta com o objetivo de tirar o melhor proveito das condições reinantes, principalmente da disponibilidade de luz e função do teor de nitrogênio foliar.

Tabela 19. Médias de $A_{m}\left(g \cdot m^{-2} \cdot h^{-1}\right.$ de $\left.C_{2}\right)$, respiração de escuro foliar $\left(g \cdot m^{-2} \cdot h^{-1}\right.$ de $\left.\mathrm{CO}_{2}\right)$ e $\varepsilon\left(\mathrm{g} \cdot \mathrm{MJ}^{-1}\right.$ de $\left.\mathrm{CO}_{2}\right)$ no estrato médio superior (A) e médio inferior (B) de três híbridos de milho com diferentes arquiteturas de parte aérea.com diferentes ângulos de inserção foliar. Estádio de 8 folhas - 34 DAE

$$
\mathrm{A}_{\mathrm{m}}
$$$$
\text { Respiração }
$$

$\varepsilon$

Híbrido Estrato A Estrato B Estrato A Estrato B Estrato A Estrato B

\begin{tabular}{lllllll}
\hline BRS 1010 & $6,19 \mathrm{~A}^{1}$ & $4,51 \mathrm{~B}$ & $0,52 \mathrm{~A}$ & $0,39 \mathrm{~A}$ & $8,48 \mathrm{~A}$ & $6,72 \mathrm{~A}$ \\
BRS 3003 & $5,90 \mathrm{~A}^{1}$ & $5,05 \mathrm{~A}$ & $0,51 \mathrm{~A}$ & $0,20 \mathrm{~B}$ & $9,30 \mathrm{~A}$ & $7,66 \mathrm{~A}$ \\
BRS 1001 & $5,47 \mathrm{~A}^{1}$ & $4,63 \mathrm{~B}$ & $0,49 \mathrm{~A}$ & $0,38 \mathrm{~A}$ & $9,61 \mathrm{~A}$ & $7,34 \mathrm{~A}$
\end{tabular}

${ }^{1}$ Médias nas linhas seguidas de letras diferentes são significativamente diferentes $(p \leq 0,05)$

Na comparação das medidas de $\mathrm{A}_{\mathrm{m}}$ realizadas nas camadas do dossel, estádio de 8fl (estrato médio superior - A, estrato médio inferior - B), e 12fl (terço superior-A, terço médio - B e terço inferior $-\mathrm{C}$ ) foram encontradas diferenças significativas em todos os híbridos avaliados. Esses resultados mostram que existe diferença de $\mathrm{A}_{\mathrm{m}}$ de acordo com a idade da folha, concordando com as observações de Dwyer \& Stewart (1996). Quanto a eficiência quântica da fotossíntese, mesmo com valores diferentes para a maioria dos híbridos, só o BRS 3003 apresentou diferença significativa para o estrato superior no estádio de 12 folhas. O mesmo híbrido também apresentou diferença de respiração no escuro entre os estratos A e B no estádio de $8 \mathrm{fl}$ e entre A e C nos estádios de $12 \mathrm{fl}$. 
Esses resultados mostram que para estimatição da assimilação de $\mathrm{CO}_{2}$ considerando todo o dossel baseada em parâmetros fisiológicos, a eleição de um valor único de $\mathrm{A}_{\mathrm{m}}$ e $\varepsilon$ para todo o ciclo deve ser evitado.

A respiração no escuro está relacionada com a disponibilidade de substrato, que por sua vez depende da capacidade fotossintética, a qual é positivamente relacionada com o teor de nitrogênio (N) foliar (Lambers, 1985). Penning de Vries (1975) relatou que a respiração esta relacionada à manutenção da atividade celular, reciclagem de proteínas e manutenção do gradiente iônico. Portanto, a respiração está correlacionada positivamente com o teor de $\mathrm{N}$ foliar. Através da análise dos dados, verifica-se que os maiores valores de respiração no escuro são observados nos estratos superiores, o de maior atividade fotossintética e metabólica.

No estádio de $12 \mathrm{f}$ e grão leitoso, observa-se uma tendência da respiração ser menor no estrato médio em relação ao estrato inferior, também ocorrendo essa tendência para a eficiência quântica da fotossíntese. Segundo Hirose \& Werner existe uma correlação positiva entre $\varepsilon$ e teor de nitrogênio foliar. Folhas sombreadas apresentam altos teores de complexos proteína-clorofila com o objetivo de melhorar a captação de energia luminosa (Thornber, 1975). Portanto, podem apresentar teores de $\mathrm{N}$ foliar superior ao estrato médio. Na fase de grão leitoso ocorre uma intensa translocação de $\mathrm{N}$ para grão com o objetivo de compor as proteínas do grão, como as folhas do estrato médio são as mais próximas, boa parte deste $\mathrm{N}$ pode estar sendo remobilizado dessas folhas, levando a um nível mais reduzido. 
Tabela 20. Médias de $A_{m}\left(g \cdot m^{-2} \cdot h^{-1}\right.$ de $\left.C_{2}\right)$, respiração de escuro foliar $\left(g \cdot m^{-2} \cdot h^{-1}\right.$ de $\left.\mathrm{CO}_{2}\right)$ e $\varepsilon\left(\mathrm{g} \cdot \mathrm{MJ}^{-1}\right.$ de $\left.\mathrm{CO}_{2}\right)$ no estrato terço superior (A), terço médio (B) e terço inferior (C) de três híbridos de milho com diferentes arquiteturas de parte aérea. Estádio de 12 folhas - 49 DAE

\begin{tabular}{cccccccccc}
\hline & \multicolumn{3}{c}{$\mathrm{A}_{\mathrm{m}}$} & \multicolumn{9}{c}{ Respiração } & & $\varepsilon$ & \\
Híbrido & A & B & C & A & B & C & A & B & C \\
\hline BRS 1010 & $7,29 A^{1}$ & $5,69 \mathrm{~B}$ & $5,00 \mathrm{~B}$ & $0,53 \mathrm{~A}$ & $0,26 \mathrm{~A}$ & $0,37 \mathrm{~A}$ & $14,15 \mathrm{~A}$ & $11,95 \mathrm{~A}$ & $11,83 \mathrm{~A}$ \\
BRS 3003 & $6,83 \mathrm{~A}^{1}$ & $4,98 \mathrm{~B}$ & $4,71 \mathrm{~B}$ & $0,56 \mathrm{~A}$ & $0,24 \mathrm{~B}$ & $0,49 \mathrm{AB}$ & $13,79 \mathrm{~A}$ & $11,29 \mathrm{~B}$ & $11,78 \mathrm{~B}$ \\
BRS 1001 & $7,48 \mathrm{~A}^{1}$ & $5,39 \mathrm{~B}$ & $4,87 \mathrm{~B}$ & $0,52 \mathrm{~A}$ & $0,37 \mathrm{~A}$ & $0,46 \mathrm{~A}$ & $13,02 \mathrm{~A}$ & $10,70 \mathrm{~A}$ & $10,87 \mathrm{~A}$
\end{tabular}

${ }^{\mathrm{T}}$ Médias nas linhas seguidas de letras diferentes são significativamente diferentes $(\mathrm{p} \leq 0,05)$

A respiração no escuro esta relacionada com a disponibilidade de substrato que a seu turno depende da capacidade fotossintética e esta última é positivamente relacionada com o teor de nitrogênio(N) foliar (Lambers, 1985). Penning de Vries (1975) também relatou que a respiração esta relacionada a manutenção da atividade celular, reciclagem de proteínas e manutenção do gradiente iônico. Portanto a respiração está correlacionada positivamente com o teor de $\mathrm{N}$ foliar. Através da análise dos dados se verifica que os maiores valores de respiração no escuro são observados nos estratos superiores, o de maior atividade fotossintética e metabólica.

No estádio de $12 \mathrm{f}$ e grão leitoso, observa-se uma tendência da respiração ser menor no estrato médio em relação ao estrato inferior, também ocorrendo esta tendência para a eficiência quântica da fotossíntese. Segundo Hirose \& Werner existe uma correlação positiva entre $\varepsilon$ e teor de nitrogênio foliar. Folhas sombreadas apresentam altos teores de complexos proteína-clorofila com o objetivo de melhorar a captação de energia luminosa (Thornber, 1975). Portanto, podem apresentar teores de $\mathrm{N}$ foliar superior ao estrato médio. $\mathrm{Na}$ fase de grão leitoso ocorre uma intensa translocação de $\mathrm{N}$ para grão com o objetivo de compor as proteínas do grão, como as folhas do estrato médio são as mais próximas, boa parte deste $\mathrm{N}$ pode estar sendo remobilizado destas folhas, levando a um nível mais reduzido. 
Tabela 21. Médias de $A_{m}\left(g \cdot m^{-2} \cdot h^{-1}\right.$ de $\left.C_{2}\right)$, respiração de escuro foliar $\left(g \cdot m^{-2} \cdot h^{-1}\right.$ de $\left.\mathrm{CO}_{2}\right)$ e $\varepsilon\left(\mathrm{g} \cdot \mathrm{MJ}^{-1}\right.$ de $\left.\mathrm{CO}_{2}\right)$ no estrato terço superior (A), terço médio (B) e terço inferior $(\mathrm{C})$ de três híbridos de milho com diferentes arquiteturas de parte aérea. Estádio de grão leitoso - 80 DAE

\begin{tabular}{ccccccc}
\hline & \multicolumn{3}{c}{ Respiração } & & \multicolumn{2}{c}{$\varepsilon$} \\
Híbrido & A & B & C & A & B & C \\
\hline BRS 1010 & 0,50 & 0,36 & 0,36 & 11,44 & 11,55 & 10,46 \\
BRS 3003 & 0,62 & 0,20 & 0,33 & 11,59 & 9,63 & 10,26 \\
BRS 1001 & 0,39 & 0,18 & 0,02 & 10,87 & 9,79 & 10,99 \\
\hline
\end{tabular}

\subsection{Eficiência de uso da radiação}

Em função da baixa correlação entre a taxa de fotossíntese medida em nível de folha e a produtividade de uma cultura, muitos modelos de crescimento empregam o parâmetro eficiência do uso da radiação.

A Figura 7 apresenta a variação da radiação global diária durante o curso do experimento. Os valores numéricos de radiação, temperatura máxima, mínima e média e precipitação diária são apresentados no Anexo 1.

Destaca-se na Figura 7 os altos níveis de radiação no mês de dezembro coincidentes com o período de enchimento de grãos.

Das medidas de interceptação avaliadas continuamente no decorrer do ciclo, através dos tubos solarímetros colocados sob o dossel da cultura, foi calculado a radiação fotossinteticamente ativa interceptada acumulada e plotada contra a fitomassa seca acumulada entre os estádios de emergência e grão pastoso. A Figura 8 apresenta as retas de regressão linear dos híbridos BRS 1010, BRS 1001 e BRS 3003. A inclinação da linha de regressão (coeficiente angular) indica a eficiência de produtividade do dossel. 




Figura 7 - Radiação total diária $\left(\mathrm{MJ} \cdot \mathrm{m}^{-2} \cdot \mathrm{dia}^{-1}\right)$ de Piracicaba-SP de 29 de setembro de 2003 (emergência) a 02 de fevereiro de 2004 (ponto de maturidade fisiológico). (Os meses são mostrados no primeiro dia de cada mês)

Normalmente, quando se aproxima do final do ciclo, a relação funcional entre PAR interceptada e fitomassa seca acumulada diminui a sua linearidade. Essa perda está relacionada aos processos de senescência que se são bem distintos dos processos de crescimento, e a presença excessiva de folhas secas, que dificultam de sobremaneira as medidas, portanto, existe dificuldade de se determinar um valor para todo o ciclo.

A falta de precisão na determinação de valor da RUE para todo o ciclo da cultura impede avaliar qual dos híbridos foi o mais eficiente no uso da radiação. Na Tabela 22 são apresentados os valores obtidos para a RUE nos períodos compreendido entre dois estádios fenológicos sucessivos. Na Tabela 23 são apresentados os valores de RUE para os períodos de crescimento vegetativo e reprodutivo e ainda um valor que compreende da emergência ao estádio de grão pastoso. 

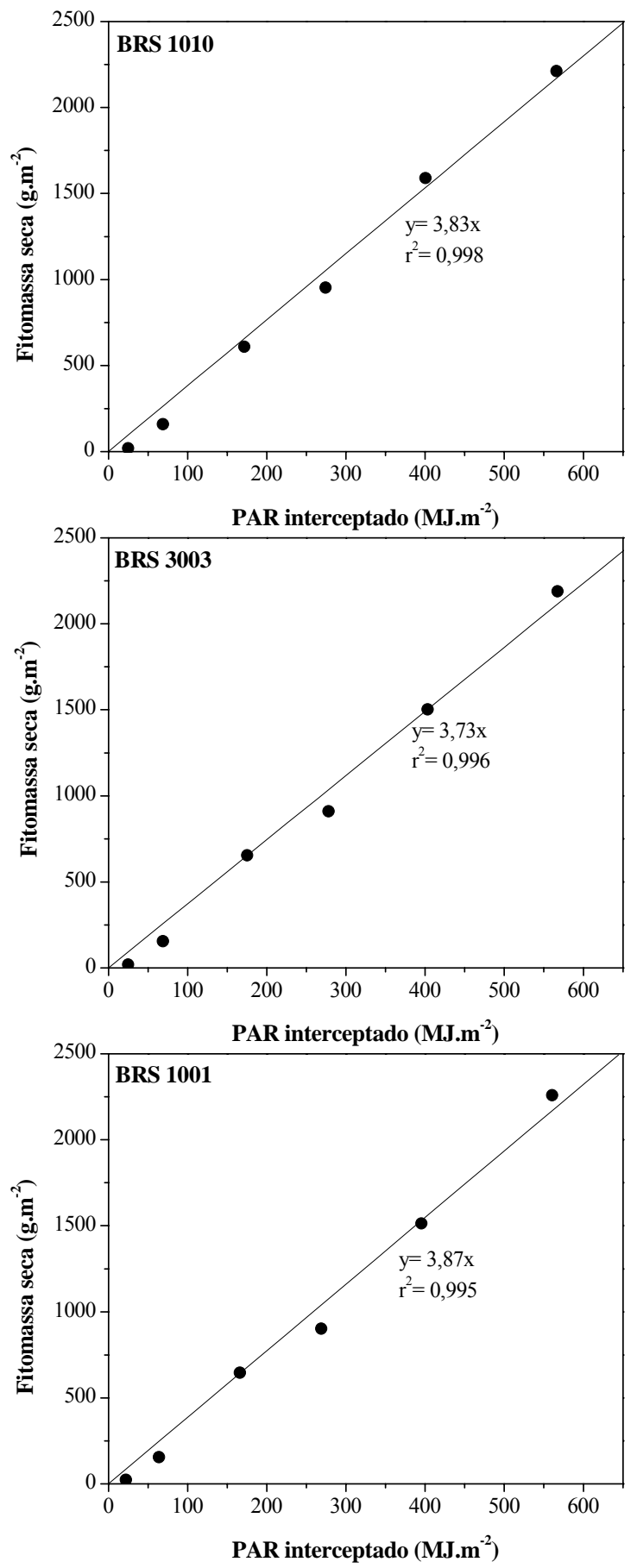

Figura 8 - Relação entre a acumulação de fitomassa seca da parte aérea e PAR interceptado acumulado dos híbridos BRS 1010, BRS 3003 e BRS 1001, da emergência ao estádio de grão pastoso. 
Dos valores apresentados na Tabela 22, destaca-se o valor da RUE para o período que vai do estádio de 12 folhas ao florescimento do híbrido BRS 1010. Esse híbrido foi superior aos demais em aproximadamente 1 g.MJ ${ }^{-1}$ de PAR interceptado.

Tabela 22. Eficiência de uso da radiação $\left(\mathrm{g} \cdot \mathrm{MJ}^{-1}\right)$ de três híbridos de milho com diferentes arquiteturas de parte aérea referente a seis fases fenológicas

\begin{tabular}{cccc}
\hline Fase & BRS 1010 & BRS 3003 & BRS 1001 \\
\hline Emergência a 4 folhas & 0,75 & 1,27 & 1,02 \\
4 a 8 folhas & 3,21 & 3,10 & 3,18 \\
8 a 12 folhas & 4,37 & 4,68 & 4,81 \\
12 folhas ao florescimento & 3,34 & 2,49 & 2,48 \\
florescimento a grão leitoso & 5,06 & 4,74 & 4,83 \\
grão leitoso a grão pastoso & 3,74 & 4,17 & 4,51 \\
grão pastoso a grão farináceo duro & 2,18 & 2,87 & 0,94 \\
\hline
\end{tabular}

A Tabela 23 mostra que o período reprodutivo é marcado por apresentar uma RUE superior ao período de crescimento vegetativo. Entre os híbridos avaliados, os valores para as fases reprodutiva, vegetativa e da emergência ao grão pastoso praticamente não apresentou diferença, mostrando que a eficiência de uso da radiação é uma característica específica da espécie, desde que mantida as mesmas condições ambientais.

Tabela 23. Eficiência de uso da radiação $\left(\mathrm{g} \cdot \mathrm{MJ}^{-1}\right)$ de três híbridos de milho com diferentes arquiteturas de parte aérea, nas fases vegetativa e reprodutiva e da emergência a grão pastoso

\begin{tabular}{cccc}
\hline Períodos & BRS 1010 & BRS 3003 & BRS 1001 \\
\hline Emergência ao florescimento & 3,47 & 3,35 & 3,36 \\
florescimento a grão farináceo duro & 3,87 & 3,95 & 3,81 \\
Emergência a grão pastoso & 3,90 & 3,86 & 4,03 \\
\hline
\end{tabular}


Diante dessa análise, um valor médio entre os três genótipos, do período da emergência a grão pastoso, pode ser adotado em modelos de crescimento de milho. $\mathrm{O}$ valor médio a ser adotado é de 3,9g.MJ ${ }^{-1}$ de PAR interceptado. Esse valor obtido para a RUE é o mesmo encontrado por Kiniry et al. (1989), o qual trabalhou com uma população de 64.000pl.ha ${ }^{-1}$, e próximo dos 3,8g. $\mathrm{MJ}^{-1}$ de PAR interceptado encontrado por Sivakumar \& Virmani (1984).

A Figura 9 mostra a variação diária da fração da radiação interceptada e do IAF durante o ciclo da cultura para os três híbridos estudados.

A variação da fração interceptada é função da variação do IAF da cultura no tempo (Figura 9).

A fração máxima interceptada ficou em torno de $90 \%$ quando o IAF se manteve próximo do seu valor máximo, situação verificada em todos os híbridos (Figura 9).

Uma pequena diferença nos gráficos apresentados na Figura 9 é quanto a proximidade dos valores de IAF à curva da fração interceptada. Pode-se observar que existe um posicionamento dos valores de IAF um pouco mais abaixo da curva da fração interceptada nos estádios de 12 folhas, florescimento e grão leitoso do híbrido BRS 1010 em relação aos demais. Essa pequena diferença indica que o BRS 1010 interceptou um pouco mais de radiação por unidade de área foliar neste período. 


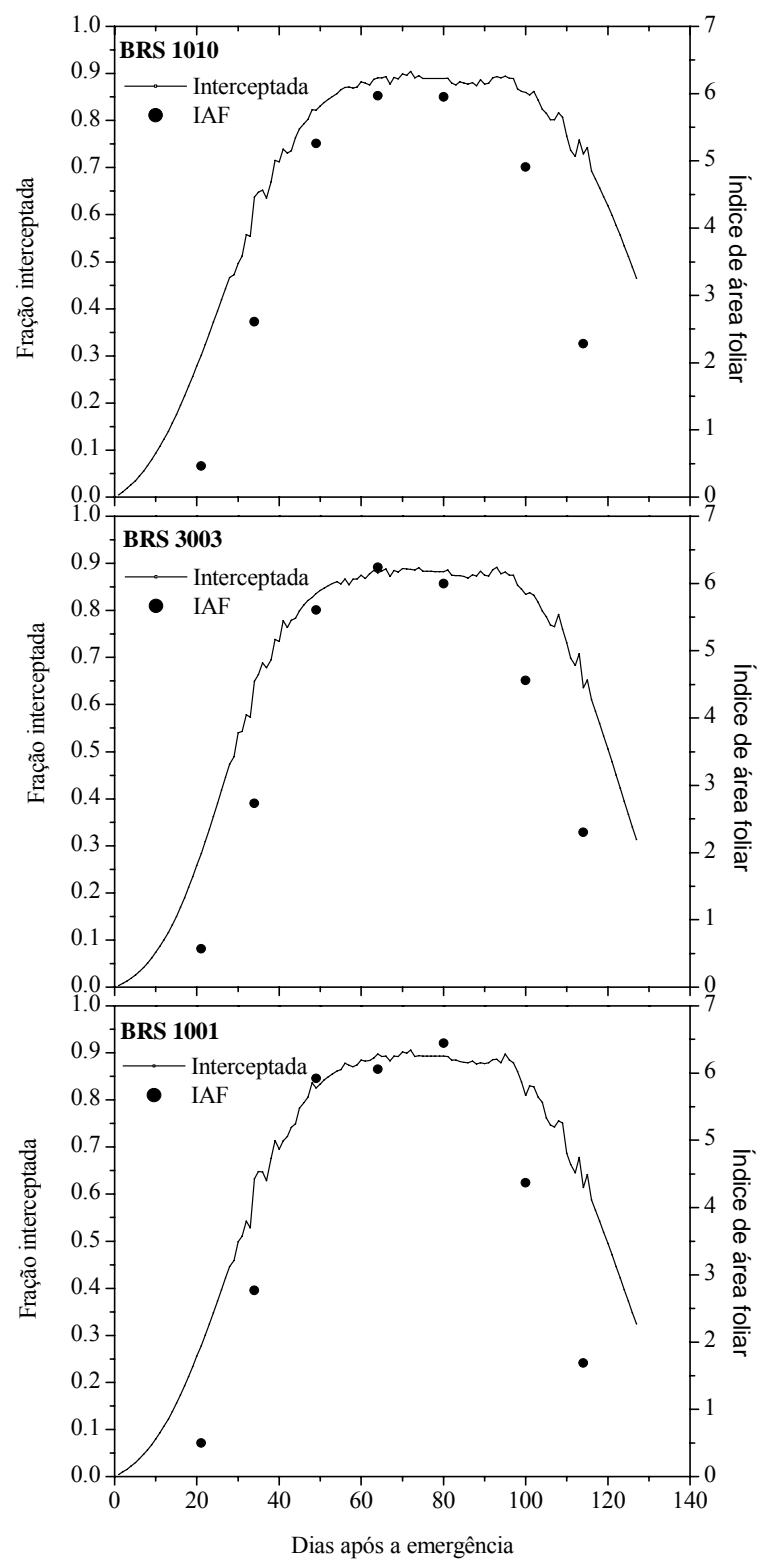

Figura 9 - Variação da fração interceptada da radiação PAR ( - $)$ e do IAF (•) durante o ciclo dos híbridos BRS 1010, BRS 3003 e BRS 1001

\subsection{Coeficiente de extinção da luz}

Em muitos modelos de crescimento de culturas, a radiação fotossinteticamente ativa interceptada (PARi) por um dossel é calculada a partir da equação baseada na Lei de Beer: PARi $=$ PAR.[1-exp(-k.IAF) $]$. 
Os valores do coeficiente de extinção (k) da luz dos híbridos BRS 1010, BRS 1001 e BRS 3003 para os estádios fenológicos de 8 folhas, 12 folhas, florescimento, grão leitoso e grão farináceo e a média dos cinco estádios são apresentados na Tabela 24. Cada valor representa a média de dez momentos do dia (8:00, 9:00, 10:00, 11:00, 12:00, 13:00, 14:00, 15:00, 16:00 e 17:00h).

Em uma análise conjunta, os valores tendem a aumentar de acordo com a evolução do ciclo da cultura, do estádio de 8 folhas ao estádio de grão pastoso. Lizaso et al. (2003) encontraram uma correlação positiva entre o valor de k e o estádio fenológico da cultura. Eles associaram os menores valores de $\mathrm{k}$ à estrutura mais vertical do dossel no início do ciclo da cultura, em que predomina a expansão foliar e o comprimento do colmo. Com o fim da emissão de novas folhas e da expansão do colmo, no estádio de pendoamento, a arquitetura tende a se tornar mais plana favorecendo a maior interceptação de PAR por unidade de área foliar, ou seja, maior k.

Analisando os três híbridos, o BRS 1010 apresentou o maior valor para k em todos os estádios de desenvolvimento, com exceção do estádio de 8 folhas, onde o BRS 3003 apresentou o maior valor, e o estádio de florescimento onde o BRS 1001 apresentou o maior valor para k. O teste de comparação das médias do valor de k obtida nos cinco estádios mostrou diferença estatística significativa entre o BRS 1010 e o BRS 1001. Na comparação entre BRS 1010 e BRS 3003 e entre BRS 3003 e BRS 1001, não foi encontrada diferença significativa entre as médias do valor de $\mathrm{k}$.

O maior valor de k para o genótipo BRS 1010, considerado aqui de arquitetura ereta, e o menor valor apresentado pelo genótipo BRS 1001, considerado aqui como de arquitetura plana até o momento.

A Figura 10 apresenta fotos dos híbridos estudados, no estádio entre o pendoamento e o florescimento. Observando o genótipo BRS 1010 (Figura 10), verificase uma razoável inclinação das folhas, a qual é melhor visualizada no ponto de inserção com o colmo, onde o ponto de curvatura da folha está bem deslocado para o terço final da folha. Na análise do BRS 1001, verifica-se um ângulo de inserção foliar mais aberto, comparado ao BRS 1010. No entanto, dada a extensão da folha e o ponto de curvatura mais centralizado nessa, verifica-se que grande porção da folha está situada em posição 
vertical em relação ao plano horizontal. Dessa forma, a rigor, não está correto classificar esse híbrido como apresentando arquitetura de parte aérea plana. O BRS 3003 apresenta arquitetura de parte aérea intermediária entre o BRS 1010 e BRS 1001.
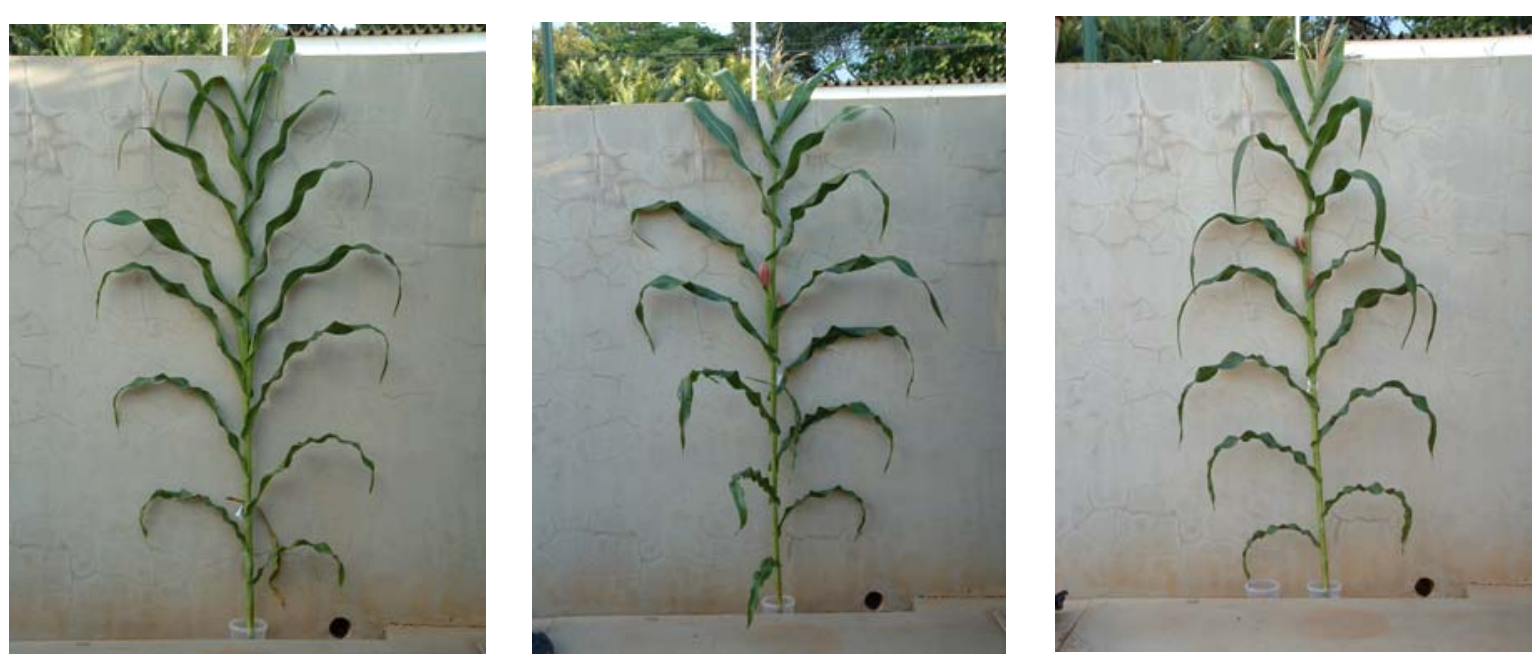

Figura 10 - Foto dos híbridos BRS 1010 (esquerda), BRS 3003 (centro) e BRS 1001 (direita)

Os valores obtidos às 12:00h (sol a pino) mostra que o BRS 1001 (arquitetura supostamente plana), com uma grande fração relativa das folhas em posição vertical em relação ao plano horizontal, permitiu uma passagem maior da luz pelo dossel que o BRS 1010 (arquitetura mais ereta). Nesse horário, o BRS 1010 apresentou grande diferença de interceptação em relação ao BRS 1001, mostrando que intercepta uma maior quantidade de luz por unidade de área foliar. Às 11:00h e às 13:00h ocorre o inverso, sendo a interceptação por unidade de área foliar do BRS 1001 superior a do BRS 1010. Essa diferença se estabelece tanto pela redução do valor de k para o BRS 1010, quanto pelo aumento do valor de k para o BRS 1001. A redução está relacionada ao ângulo de entrada dos raios solares no dossel da cultura. Para o BRS 1010, esse ângulo de entrada 
é próximo ao ângulo foliar médio, permitindo uma maior passagem da luz. Para o BRS 1010, o ângulo de entrada da luz é próximo ao das folhas caídas de forma mais frontal.

$\mathrm{Na}$ Tabela 25 são apresentados os valores de $\mathrm{k}$ ao longo do dia. Esses valores representam a média de cinco dias referentes aos estádios de 8 folhas, 12 folhas, florescimento, grão leitoso e grão pastoso. Podemos observar que existe uma variação horária do valor de $\mathrm{k}$, independente do genótipo. Nas primeiras horas e nas últimas horas do período luminoso os valores de k são maiores e em torno das 12:00h os valores são menores. Esta variação no dia foi também verificada por Flénet et al. (1996).

A maioria dos modelos de crescimento adota um valor para $\mathrm{k}$ maior do que o encontrado no estudo, o CERES-Maize adota um valor de k igual a 0,65 (Kiniry et al., 1997) e o Hibrid-Maize um valor de k igual a 0,55 (Yang et al., 2004). O valor encotrado neste estudo é semelhante ao valor encontrado por Flénet et al. (1996). Estes autores encontraram para o milho plantado com espaçamento de $0,66 \mathrm{~m}$ entre fileiras um valor de $\mathrm{k}$ igual a 0,398 , e para o milho plantado no espaçamento de $1,00 \mathrm{~m}$ entre fileiras um valor de $\mathrm{k}$ igual a 0,336 , considerando o espaçamento de 0,8 adotado neste estudo, os valores encontrados estão dentro do projeto para esse espaçamento no estudo de Flénet et al. (1996).

Tabela 24. Coeficiente de extinção da luz de três híbridos de milho com diferentes arquiteturas de parte aérea calculados em cinco estádios de desenvolvimento e a sua média

\begin{tabular}{cccc}
\hline Estádio & BRS 1010 & BRS 3003 & BRS 1001 \\
\hline 8 folhas & 0,368 & 0,378 & 0,324 \\
12 folhas & 0,340 & 0,326 & 0,306 \\
Florescimento & 0,363 & 0,343 & 0,372 \\
Grão leitoso & 0,374 & 0,358 & 0,341 \\
Grão pastoso & 0,426 & 0,390 & 0,388 \\
Média & $0,374 \mathrm{~A}^{1}$ & $0,359 \mathrm{AB}$ & $0,346 \mathrm{~B}$ \\
\hline
\end{tabular}

${ }^{1}$ Médias seguidas de letra diferente são distintas significativas pelo Teste-t $(\mathrm{p} \geq 0,05)$ 
O modelo CERES-Maize prediz o número de grãos por planta como uma função da média diária da radiação fotossintéticamente ativa interceptada, ao redor do período de espigamento.

Os dados apresentados indicam que pelo maior valor de k e da RUE nos estádios de florescimento e grão leitoso, o híbrido BRS 1010, interceptou mais radiação e de forma mais eficiente transformou energia luminosa em carboidratos. A melhor distribuição de radiação favorecida pela arquitetura de dossel pode ainda ter melhorado as relações fonte-dreno, considerando o dreno mais importante o grão.

Tabela 25. Variação horária dos valores médios do coeficiente de extinção (k) da luz de três híbridos de milho, com diferentes arquiteturas de parte aérea, calculados como a média de cinco diferentes estádios de desenvolvimento

\begin{tabular}{cccc}
\hline Hora & BRS 1010 & BRS 3003 & BRS 1001 \\
\hline $8: 00$ & 0,421 & 0,414 & 0,389 \\
$9: 00$ & 0,404 & 0,404 & 0,370 \\
$10: 00$ & 0,394 & 0,387 & 0,323 \\
$11: 00$ & 0,344 & 0,372 & 0,364 \\
$12: 00$ & 0,378 & 0,303 & 0,311 \\
$13: 00$ & 0,352 & 0,331 & 0,370 \\
$14: 00$ & 0,345 & 0,339 & 0,312 \\
$15: 00$ & 0,336 & 0,328 & 0,312 \\
$16: 00$ & 0,374 & 0,354 & 0,346 \\
$17: 00$ & 0,395 & 0,357 & 0,366
\end{tabular}

\subsection{Desfolhamento}

Os resultados da avaliação da reação dos híbridos BRS 1010, BRS 3003, BRS 1001 ao desfolhamento estratificado do dossel (A - superior; B - médio, C - inferior e D - controle) após a antese são apresentados nas Tabelas 26 e 27 e Figuras 11 e 12. 
$\mathrm{Na}$ época da desfolha, a composição dos estratos em termos de índice de área foliar relativo foi semelhante para os três genótipos: 35\%:45\%:20\%; 36\%:45\%:19\%; 33\%:44:23\%, para os estrados A:B:C, dos genótipos BRS 1010, BRS 3003 e BRS 1001 respectivamente.

A retirada do terço superior acarretou a redução na produtividade relativa de $36 \%, 47 \%$ e $45 \%$ para os genótipos BRS 1010, BRS 3003 e BRS 1001, respectivamente (Figura 11).

A retirada do terço médio causou a redução na produtividade relativa de $14 \%$, $21 \%$ e 18\% nos genótipos BRS 1010, 3003 e 1001 (Figura 11).

A retirada do terço inferior causou a redução na produtividade relativa de $2,8 \% \mathrm{e}$ 4,4\% nos híbridos BRS 3003 e 1001, respectivamente e levou a um acréscimo de 2\% na produção relativa do híbrido BRS 1010.

Tabela 26. Teste de Tukey para comparação de médias de fitomassa de grãos da espiga (g.espiga $^{-1}$ ) entre três híbridos (colunas) e dentro de cada híbrido de milho (linha), submetido ao desfolhamento dos terços superior (A), terço médio (B), terço inferior (C) e controle sem desfolhamento (D) do dossel vertical após a antese

\begin{tabular}{ccccccc}
\hline Híbrido & A & B & C & D & DMS & CV(\%) \\
\hline BRS 1010 & $106,1 \mathrm{Aa}$ & $143,2 \mathrm{Ab}$ & $169,6 \mathrm{Ac}$ & $166,0 \mathrm{ABbc}$ & 24,2 & 10,0 \\
BRS 3003 & $94,1 \mathrm{Aa}$ & $141,1 \mathrm{Ab}$ & $174,3 \mathrm{Ac}$ & $179,3 \mathrm{Ac}$ & 12,2 & 27,2 \\
BRS 1001 & $84,6 \mathrm{Aa}$ & $127,7 \mathrm{Ab}$ & $148,2 \mathrm{Bbc}$ & $155,0 \mathrm{Bc}$ & 23,6 & 11,8 \\
DMS & 27,3 & 34,6 & 16,4 & 17,3 & & \\
CV (\%) & 17,1 & 16,8 & 6,7 & 6,9 & & \\
\hline
\end{tabular}

Médias seguidas pela mesma letra maiúscula nas colunas e minúsculas nas linhas não diferem estatisticamente entre si $(\mathrm{p} \leq 0,05)$

Médias seguidas de letras diferentes maiúsculas nas colunas e minúsculas nas linhas diferem estatisticamente entre si $(\mathrm{p} \leq 0,05)$ 
Esses resultados mostram que a retirada do estrato superior na época da antese provoca uma redução média entre os genótipos de $43 \%$ na produção relativa, mesmo tendo uma participação média entre os genótipos de $35 \%$ do IAF total.

A retirada do estrato médio causou uma redução de $18 \%$ na produção relativa, enquanto a sua participação relativa na composição do IAF representava $45 \%$.

Grande parte dos fotoassimilados destinados ao enchimento dos grãos são provenientes da fotossíntese corrente no período.

A diminuição da produção foi resultado da redução do peso da espiga, pelo decréscimo do número e tamanho de grãos, não ocorrendo ausência de formação de espigas (Figura 12).

A região que mais é mais limitada no desenvolvimento dos grãos é a porção apical quando da retirada do estrato superior (Figura 12), e é mais gradativo quando a desfolha se estabelece de cima para baixo. Sendo assim, os grãos da base da espiga são formados pelos carboidratos translocados de reservas do colmo e, os da porção mais apical, de carboidratos provenientes da fotossíntese corrente, dessa forma estabelecendo uma ligação fonte-dreno específica, já relacionado em outras culturas.

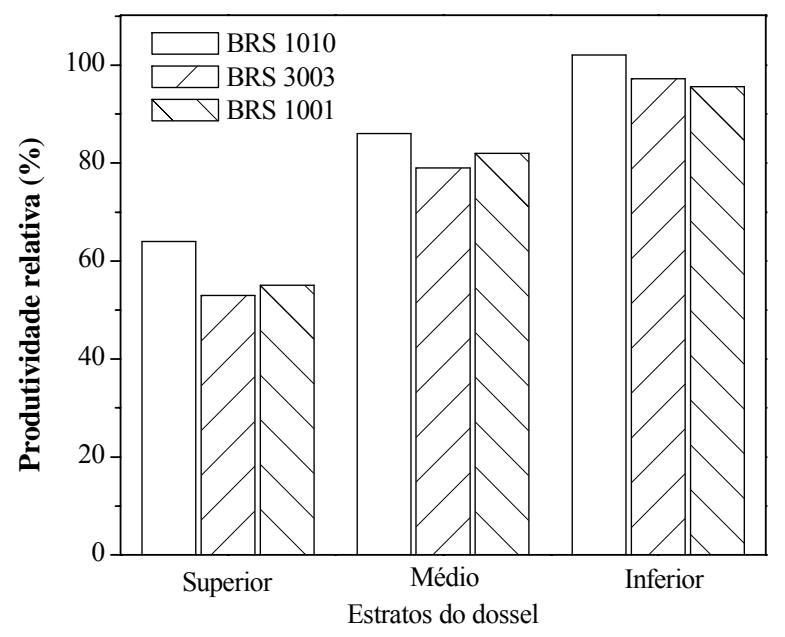

Figura 11 - Produtividade relativa (\%) dos híbridos BRS 1010, BRS 3003 e BRS 1001, submetidos a tratamento de desfolha dos estratos, superior, médio e inferior após o período da antese 
O híbrido BRS 1010 foi o híbrido que apresentou o desempenho à desfolha mais diferenciado dos outros genótipos. Ele apresentou as menores reduções na produtividade relativa, sendo mais notada a diferença relacionada a retirada do estrato A. Tal resposta mostra que esse híbrido de arquitetura ereta apresenta um modelo de interação da radiação com o dossel que permite que chegue às folhas do estrato $\mathrm{B}$ um quantidade de radiação superior a que recebe o mesmo estrato nos outros híbridos. Esse desempenho permitiu ao híbrido BRS 1010 lidar mais eficientemente com o aumento da radiação no estrato B, quando foi retirado o terço superior, levando a uma queda menor na produtividade.
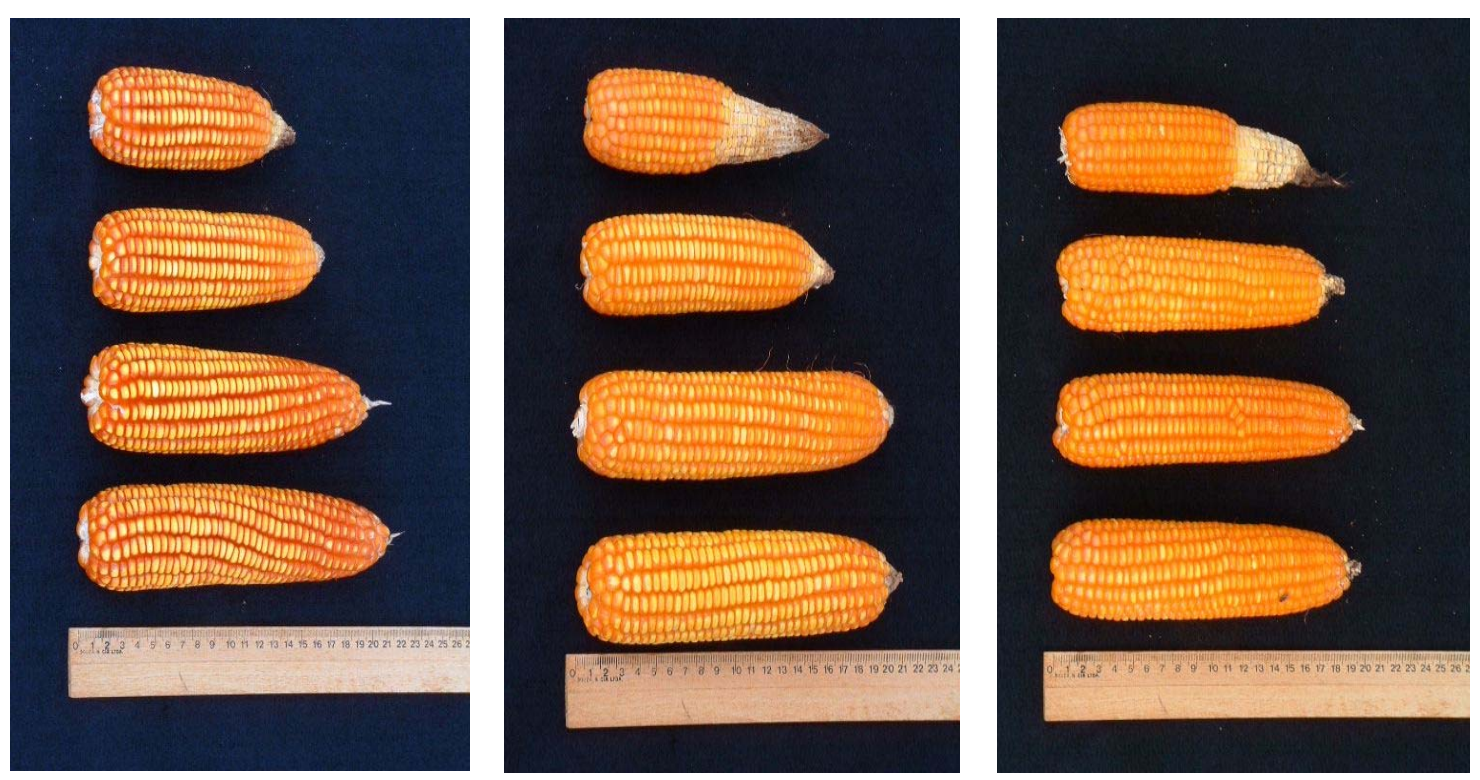

Figura 12 - Foto das espigas dos híbridos BRS 1010, BRS 3003 e BRS 1001 obtidas de plantas que sofreram desfolhamento na época da polinização. (A) terço superior, (B) terço médio, (C) terço inferior e (D) controle

A retirada do estrato $\mathrm{C}$ do BRS 1010 teve uma reação positiva na produtividade, esse ganho de $2 \%$ pode ser relacionado com a fotossíntese líquida negativa nesse estrato, já que tal híbrido apresenta o maior coeficiente de extinção entre os três observados. 
Tabela 27. Teste de Tukey para comparação de médias de fitomassa de grãos da espiga $\left(\right.$ g.espiga $^{-1}$ ) para o conjunto de três híbridos de milho submetidos ao desfolhamento do terço superior (A), terço médio (B), terço inferior (C) e controle sem desfolhamento (D) do dossel vertical após a antese

\begin{tabular}{ccccc}
\hline Híbrido & $\mathrm{A}$ & $\mathrm{B}$ & $\mathrm{C}_{0}$ & $\mathrm{D}$ \\
\hline Conjunto & $94,4 \mathrm{a}^{1}$ & $137,3 \mathrm{~b}^{1}$ & $164,0 \mathrm{c}^{2}$ & $166,8 \mathrm{c}^{2}$ \\
DMS & 15,4 & & & \\
CV \% & 12,7 & & &
\end{tabular}

${ }^{1}$ Médias seguidas de letras diferentes nas linhas diferem estatisticamente entre si $(p \leq 0,05)$ 


\section{CONCLUSÕES}

De acordo com os resultados obtidos, nas condições do experimento, pode-se concluir que: (i) a arquitetura de parte aérea da cultura de milho afeta a interceptação de radiação solar na população de 66.000 plantas.ha $^{-1}$; (ii) a taxa de assimilação de dióxido de carbono máxima da folha recém madura varia com o estádio de desenvolvimento fenológico de forma crescente da emergência ao estádio de doze folhas; (iii) para uma determinada folha, a taxa de assimilação de dióxido de carbono máxima é sempre constante da emergência ao estádio de doze folhas; (iv) a área foliar específica diminui com a evolução do ciclo da cultura; (v) a ordem de grandeza da eficiência do uso da radiação pela cultura de milho é $3,9 \mathrm{~g} \cdot \mathrm{MJ}^{-1}$; (vi) a maior produtividade do genótipo de arquitetura foliar ereta se deve à maior interceptação de radiação por unidade de área foliar, com conseqüente maior taxa assimilatória líquida; (vii) genótipo de arquitetura foliar ereta apresenta menor queda de produtividade de grãos quando o terço superior do dossel é desfolhado; e (viii) o coeficiente de extinção da luz deve ser determinado especificamente para cada genótipo, levando em consideração a variação temporal (escala horária) durante o dia. 
ANEXO 
Tabela 28. Temperatura, radiação solar e precipitação

\begin{tabular}{|c|c|c|c|c|c|}
\hline Data & $\begin{array}{l}\text { Radiação } \\
\text { MJ.m }{ }^{-2} \cdot d^{-1}\end{array}$ & $\begin{array}{c}\text { Temp. min } \\
{ }^{\circ} \mathrm{C}\end{array}$ & $\begin{array}{c}\text { Temp. max } \\
{ }^{\circ} \mathrm{C}\end{array}$ & $\begin{array}{c}\text { Temp. med } \\
{ }^{\circ} \mathrm{C}\end{array}$ & $\begin{array}{c}\text { Precipitação } \\
\mathrm{mm}\end{array}$ \\
\hline 29-Set & 4,75 & 17,07 & 28,72 & 22,89 & 0 \\
\hline $30-$ Set & 22,80 & 15,95 & 29,58 & 22,76 & 0 \\
\hline 01-Out & 23,48 & 13,19 & 31,03 & 22,11 & 0 \\
\hline 02-Out & 22,60 & 13,88 & 33,11 & 23,49 & 0 \\
\hline 03-Out & 22,40 & 15,33 & 33,76 & 24,54 & 0 \\
\hline 04-Out & 22,93 & 16,77 & 34,13 & 25,45 & 0 \\
\hline 05-Out & 22,17 & 16,09 & 35,14 & 25,61 & 0 \\
\hline 06-Out & 14,17 & 19,47 & 31,22 & 25,34 & 0 \\
\hline 07-Out & 4,46 & 17,99 & 25,07 & 21,53 & 15,3 \\
\hline 08-Out & 15,55 & 17,42 & 27,31 & 22,36 & 1,7 \\
\hline 09-Out & 15,71 & 17,4 & 32,26 & 24,83 & 7,1 \\
\hline 10-Out & 16,87 & 17,69 & 27,15 & 22,42 & 0 \\
\hline 11-Out & 3,57 & 14,33 & 18,51 & 16,42 & 37,6 \\
\hline 12-Out & 17,32 & 13,04 & 24,41 & 18,72 & 0 \\
\hline 13-Out & 24,51 & 14,16 & 26,83 & 20,49 & 0 \\
\hline 14-Out & 23,92 & 12,84 & 25,25 & 19,04 & 0 \\
\hline 15-Out & 26,09 & 11,77 & 26,67 & 19,22 & 0 \\
\hline 16-Out & 26,43 & 12,25 & 27,42 & 19,83 & 0 \\
\hline 17-Out & 26,47 & 10,75 & 31,1 & 20,92 & 0 \\
\hline 18-Out & 24,65 & 14,11 & 33,64 & 23,87 & 0 \\
\hline 19-Out & 22,11 & 16,55 & 34,92 & 25,73 & 0 \\
\hline 20-Out & 17,61 & 18,48 & 29,76 & 24,12 & 0,0 \\
\hline 21-Out & 8,81 & 18,78 & 27,95 & 23,36 & 1,1 \\
\hline 22-Out & 19,71 & 18,17 & 28,54 & 23,35 & 0,2 \\
\hline 23-Out & 16,86 & 18,42 & 27,56 & 22,99 & 0,0 \\
\hline
\end{tabular}


Tabela 28. Temperatura, radiação solar e precipitação

\begin{tabular}{|c|c|c|c|c|c|}
\hline Data & $\begin{array}{l}\text { Radiação } \\
\text { MJ.m }{ }^{-2} \cdot \mathrm{d}^{-1}\end{array}$ & $\begin{array}{c}\text { Temp. min } \\
{ }^{\circ} \mathrm{C}\end{array}$ & $\begin{array}{c}\text { Temp. max } \\
{ }^{\circ} \mathrm{C}\end{array}$ & $\begin{array}{c}\text { Temp. med } \\
{ }^{\circ} \mathrm{C}\end{array}$ & $\begin{array}{c}\text { Precipitação } \\
\mathrm{mm}\end{array}$ \\
\hline 24-Out & 22,27 & 17,87 & 31,68 & 24,77 & 0,0 \\
\hline 25-Out & 23,05 & 18,21 & 33,51 & 25,86 & 0,0 \\
\hline 26-Out & 18,95 & 20,26 & 34,53 & 27,39 & 0,0 \\
\hline 27-Out & 4,75 & 19,33 & 23,28 & 21,30 & 20,7 \\
\hline 28-Out & 9,09 & 17,43 & 22,95 & 20,19 & 3,3 \\
\hline 29-Out & 16,21 & 17,14 & 27,21 & 22,17 & 1,3 \\
\hline 30-Out & 21,93 & 17,45 & 29,32 & 23,38 & 0,0 \\
\hline 31-Out & 24,77 & 16,68 & 31,08 & 23,88 & 0,0 \\
\hline 01-Nov & 9,13 & 19,03 & 25,79 & 22,41 & 2,4 \\
\hline 02-Nov & 7,84 & 15,16 & 21,12 & 18,14 & 2,0 \\
\hline 03-Nov & 20,22 & 14,28 & 23,55 & 18,91 & 0,0 \\
\hline 04-Nov & 27,56 & 11,93 & 25,85 & 18,89 & 0,0 \\
\hline 05-Nov & 17,68 & 13,71 & 27,63 & 20,67 & 0,3 \\
\hline 06-Nov & 15,04 & 16,41 & 26,26 & 21,33 & 0,0 \\
\hline 07-Nov & 20,89 & 16,54 & 29,47 & 23,00 & 5,3 \\
\hline 08-Nov & 27,37 & 14,33 & 30,04 & 22,18 & 0,0 \\
\hline 09-Nov & 25,78 & 16,95 & 32,29 & 24,62 & 0,0 \\
\hline 10-Nov & 25,83 & 17,64 & 34,59 & 26,11 & 0,0 \\
\hline 11-Nov & 24,54 & 17,5 & 35,79 & 26,64 & 0,0 \\
\hline 12-Nov & 21,76 & 21,82 & 35,64 & 28,73 & 0,0 \\
\hline 13-Nov & 8,81 & 19,95 & 26,25 & 23,10 & 9,7 \\
\hline 14-Nov & 18,77 & 18,04 & 27,72 & 22,88 & 0,0 \\
\hline 15-Nov & 24,73 & 16,45 & 31,54 & 23,99 & 0,0 \\
\hline 16-Nov & 23,00 & 19,52 & 32,34 & 25,93 & 2,9 \\
\hline 17-Nov & 9,00 & 19,6 & 28,81 & 24,20 & 53,6 \\
\hline 18-Nov & 15,72 & 19,99 & 28,53 & 24,26 & 4,3 \\
\hline
\end{tabular}


Tabela 28. Temperatura, radiação solar e precipitação

\begin{tabular}{|c|c|c|c|c|c|}
\hline Data & $\begin{array}{l}\text { Radiação } \\
\text { MJ.m }{ }^{-2} \cdot \mathrm{d}^{-1}\end{array}$ & $\begin{array}{c}\text { Temp. min } \\
{ }^{\circ} \mathrm{C}\end{array}$ & $\begin{array}{c}\text { Temp. max } \\
{ }^{\circ} \mathrm{C}\end{array}$ & $\begin{array}{c}\text { Temp. med } \\
{ }^{\circ} \mathrm{C}\end{array}$ & $\begin{array}{c}\text { Precipitação } \\
\mathrm{mm}\end{array}$ \\
\hline 19-Nov & 11,31 & 18,74 & 25,3 & 22,02 & 0,0 \\
\hline 20-Nov & 29,64 & 16,22 & 29,29 & 22,75 & 0,0 \\
\hline 21-Nov & 20,16 & 17,3 & 27,18 & 22,24 & 0,0 \\
\hline 22-Nov & 24,50 & 17,4 & 30,16 & 23,78 & 0,0 \\
\hline 23-Nov & 17,98 & 18,95 & 28,93 & 23,94 & 2,1 \\
\hline 24-Nov & 8,22 & 19,06 & 26,51 & 22,78 & 21,6 \\
\hline 25-Nov & 25,36 & 18,68 & 31,09 & 24,88 & 0,0 \\
\hline 26-Nov & 13,23 & 19,93 & 27,27 & 23,60 & 4,6 \\
\hline 27-Nov & 20,41 & 19,38 & 30,75 & 25,06 & 0,8 \\
\hline 28-Nov & 11,29 & 19,37 & 23,94 & 21,65 & 2,4 \\
\hline 29-Nov & 23,61 & 18,02 & 29,63 & 23,82 & 0,0 \\
\hline 30-Nov & 21,47 & 16,58 & 31,35 & 23,96 & 26,2 \\
\hline 01-Dez & 11,47 & 19,59 & 26,54 & 23,06 & 28,5 \\
\hline 02-Dez & 23,63 & 20,53 & 31,82 & 26,17 & 0,0 \\
\hline 03-Dez & 25,20 & 20,61 & 31,15 & 25,88 & 0,7 \\
\hline 04-Dez & 13,38 & 21,13 & 28,09 & 24,61 & 3,7 \\
\hline 05-Dez & 13,73 & 20,75 & 28,09 & 24,42 & 1,7 \\
\hline 06-Dez & 17,81 & 20,3 & 29,5 & 24,9 & 0,0 \\
\hline 07-Dez & 15,69 & 19,81 & 28,18 & 23,99 & 4,3 \\
\hline 08-Dez & 19,57 & 20,42 & 30,46 & 25,44 & 0,1 \\
\hline 09-Dez & 5,87 & 18,69 & 24,33 & 21,51 & 15,2 \\
\hline 10-Dez & 21,15 & 16,27 & 28,62 & 22,44 & 0,3 \\
\hline 11-Dez & 26,70 & 21,71 & 33 & 27,35 & 0,0 \\
\hline 12-Dez & 11,99 & 17,96 & 26,34 & 22,15 & 12,9 \\
\hline
\end{tabular}


Tabela 28. Temperatura, radiação solar e precipitação

\begin{tabular}{|c|c|c|c|c|c|}
\hline Data & $\begin{array}{l}\text { Radiação } \\
\text { MJ.m }{ }^{-2} \cdot d^{-1}\end{array}$ & $\begin{array}{c}\text { Temp. min } \\
{ }^{\circ} \mathrm{C}\end{array}$ & $\begin{array}{c}\text { Temp. max } \\
{ }^{\circ} \mathrm{C}\end{array}$ & $\begin{array}{c}\text { Temp. med } \\
{ }^{\circ} \mathrm{C}\end{array}$ & $\begin{array}{c}\text { Precipitação } \\
\mathrm{mm}\end{array}$ \\
\hline 13-Dez & 26,31 & 18,22 & 30,88 & 24,55 & 0,0 \\
\hline 14-Dez & 23,79 & 19,5 & 33,72 & 26,61 & 0,0 \\
\hline 15-Dez & 25,46 & 20,65 & 34,26 & 27,45 & 5,6 \\
\hline 16-Dez & 24,38 & 20,97 & 34,3 & 27,63 & 2,8 \\
\hline 17-Dez & 20,21 & 19,72 & 26,21 & 22,96 & 0,0 \\
\hline 18-Dez & 23,47 & 18,88 & 28,13 & 23,50 & 0,0 \\
\hline 19-Dez & 21,35 & 18,44 & 31,53 & 24,98 & 0,0 \\
\hline 20-Dez & 23,31 & 19,92 & 32,29 & 26,10 & 1,9 \\
\hline 21-Dez & 19,80 & 19,71 & 32,42 & 26,06 & 3,3 \\
\hline 22-Dez & 23,84 & 19,37 & 30,38 & 24,87 & 17,9 \\
\hline 23-Dez & 19,44 & 19,49 & 28,78 & 24,13 & 1,4 \\
\hline 24-Dez & 23,24 & 17,67 & 25,69 & 21,68 & 0,0 \\
\hline 25-Dez & 26,97 & 16,24 & 29,03 & 22,63 & 0,0 \\
\hline 26-Dez & 26,03 & 18,28 & 30,23 & 24,25 & 0,0 \\
\hline 27-Dez & 25,51 & 18,19 & 30,27 & 24,23 & 0,0 \\
\hline 28-Dez & 26,11 & 17,82 & 31,69 & 24,75 & 0,0 \\
\hline 29-Dez & 20,54 & 18,92 & 30,23 & 24,57 & 0,0 \\
\hline 30-Dez & 22,69 & 19,88 & 31,56 & 25,72 & 0,0 \\
\hline 31-Dez & 10,27 & 20,38 & 28,6 & 24,49 & 32,4 \\
\hline 01-Jan & 9,58 & 18,82 & 24,01 & 21,41 & 23,6 \\
\hline 02-Jan & 9,73 & 16,72 & 21,08 & 18,9 & 0,0 \\
\hline 03-Jan & 20,05 & 16,88 & 26,52 & 21,7 & 0,0 \\
\hline 04-Jan & 20,74 & 17,8 & 29,05 & 23,42 & 0,0 \\
\hline 05-Jan & 25,03 & 17,65 & 30,77 & 24,21 & 0,0 \\
\hline 06-Jan & 20,98 & 17,79 & 30,83 & 24,31 & 0,0 \\
\hline 07-Jan & 12,47 & 18,64 & 24,2 & 21,42 & 19,3 \\
\hline
\end{tabular}


Tabela 28. Temperatura, radiação solar e precipitação

\begin{tabular}{|c|c|c|c|c|c|}
\hline Data & $\begin{array}{l}\text { Radiação } \\
\text { MJ.m }{ }^{-2} \cdot d^{-1}\end{array}$ & $\begin{array}{c}\text { Temp. min } \\
{ }^{\circ} \mathrm{C}\end{array}$ & $\begin{array}{c}\text { Temp. max } \\
{ }^{\circ} \mathrm{C}\end{array}$ & $\begin{array}{c}\text { Temp. med } \\
{ }^{\circ} \mathrm{C}\end{array}$ & $\begin{array}{c}\text { Precipitação } \\
\text { mm }\end{array}$ \\
\hline 08-Jan & 11,03 & 18,95 & 26,14 & 22,54 & 21,8 \\
\hline 09-Jan & 13,55 & 19,58 & 28,08 & 23,83 & 9,9 \\
\hline 10-Jan & 17,70 & 19,3 & 28,84 & 24,07 & 0,0 \\
\hline 11-Jan & 26,89 & 18,12 & 32,02 & 25,07 & 0,0 \\
\hline 12-Jan & 22,09 & 21,15 & 31,37 & 26,26 & 0,0 \\
\hline 13-Jan & 27,60 & 19,31 & 31,4 & 25,35 & 0,0 \\
\hline 14-Jan & 21,57 & 18,77 & 30,57 & 24,67 & 0,0 \\
\hline 15-Jan & 24,79 & 20,88 & 32,49 & 26,68 & 1,7 \\
\hline 16-Jan & 24,98 & 19,37 & 30,28 & 24,82 & 0,0 \\
\hline 17-Jan & 28,85 & 16,61 & 29,44 & 23,02 & 0,0 \\
\hline 18-Jan & 29,39 & 16,92 & 30,11 & 23,51 & 0,0 \\
\hline 19-Jan & 23,83 & 14,99 & 30,56 & 22,77 & 0,0 \\
\hline 20-Jan & 15,50 & 18,59 & 28,67 & 23,63 & 0,0 \\
\hline 21-Jan & 7,52 & 19,75 & 25,14 & 22,44 & 0,0 \\
\hline 22-Jan & 11,18 & 19,63 & 27,42 & 23,52 & 0,4 \\
\hline 23-Jan & 18,15 & 19,32 & 31,49 & 25,40 & 1,6 \\
\hline 24-Jan & 10,43 & 20,04 & 26,28 & 23,16 & 1,4 \\
\hline 25-Jan & 11,66 & 20,27 & 28,85 & 24,56 & 27,7 \\
\hline 26-Jan & 4,54 & 19,13 & 23,14 & 21,13 & 65,6 \\
\hline 27-Jan & 6,59 & 19,61 & 23,18 & 21,39 & 16,2 \\
\hline 28-Jan & 10,88 & 20,56 & 26,99 & 23,77 & 2,1 \\
\hline 29-Jan & 18,33 & 20,84 & 31,31 & 26,07 & 0,8 \\
\hline 30-Jan & 22,44 & 19,1 & 31,87 & 25,48 & 22,1 \\
\hline 31-Jan & 16,10 & 18,65 & 31,04 & 24,84 & 0,0 \\
\hline $01-\mathrm{Fev}$ & 19,58 & 19,86 & 29,89 & 24,87 & 0,0 \\
\hline 02-Fev & 23,57 & 18,54 & 32,11 & 25,32 & 0,0 \\
\hline
\end{tabular}




\section{REFERÊNCIAS BIBLIOGRÁFICAS}

AFUAKWA, J.J.; CROOKSTON, R.K.; JONES, R.J. Effect of temperature and sucrose availability on kernel black layer development in maize. Crop Science, v.24, n.2, p.285-288, 1984.

AHMADZADEH, A.; LEE, E.A.; TOLLENNAAR, M. Heterosis for leaf $\mathrm{CO}_{2}$ exchange rate during the grain-filling period maize. Crop Science, v.44, p.2095-2100, 2004.

ALFONSI, R.R. Agrometeorologia: importância e aplicações. CPG- Fitotecnia,. Piracicaba: ESALQ/USP. 1991. 23p.

ALLISON, J.C.S. \& WATSON, D.J. The production and distribution of dry matter in maize after flowering. Annals of Botany, v.30, n. 119, p.399-391, 1966.

ALLISON, J.C.S. Aspects of nitrogen uptake and distribution in maize. Annals of Apllied Biology, v.104, n.2, p. 357-365, 1984.

ALUKO, G.K.; FISCHER, K.S. The effect of changes of assimilate supply around flowering on grain sink size and yield of maize (Zea mays L.) cultivars of tropical and temperate adaptation. Australian Journal of Agricultural Research, v.39, p.153-161, 1988.

ANDRADE, F.H.; UHART, S.A.; ARGUISSAIN, G.G.; RUIZ, R.A. Radiation use efficiency of maize grown in a cool area. Field Crops Research, n.28, p.345-354, 1992.

ANDRADE, F.H.; UHART, S.A.; CIRILO, A. Temperature affects radiation use efficiency in maize. Field Crops Research, n.32, p.17-25, 1993.

ASSIS, F.N.; ARRUDA, MENDEZ, M.E.G. Relação entre radiação fotossintética ativa e radiação global. Pesquisa Agropecuária Brasileira, v.2, n.7, p.797-800, 1989. 
BEADLE, C.L.; LONG, S.P.; IMBAMBA, S.K.; HALL, D.O.; OLEMBO, R.J. Photosynthesis in relation to plant production in terrestrial environments. London: Tycooly/Cassel, 1985.235p

BERGONCI, J.L.; BERGAMASCHI, H. Ecofisiologia do milho (compact disc). In: CONGRESSO NACIONAL DE MILHO E SORGO, 24., Florianópolis, 2002. Anais. Florianópolis:ABMS, 2002.

BIRCH, C.J.; HAMMER, G.L., RICKERT, K.G. Dry matter accumulation and distribution in five cultivars of maize (Zea mays L.): relationship and procedures for use in crop modelling. Australian Journal Agricultural Research, v.50, p.513$527,1999$.

BISCOE, P.U.; GALLAGHER, J.N. Weather, dry matter production and yield. In: LANDSBER, J.J.; CUTTING, C.U. (Ed.). Environmental effects on crop physiology.London: Academic Press, 1977, 198p.

BOEDHRAM, N.; ARKEBAUER, T.J.; BATCHELOR, W.D. Season-long characterization of vertical distribution of leaf area in corn. Agronomy Journal, v.93, p.1235-1242, 2001.

BOOTE, K.J.; JONES, J.W.; PICKERING, N.B. Potential uses and limitations of crops models. Agronomy Journal, v.88, p. 704-716, 1996.

BRISSON, N.; GARY, C.; JUSTES, E.; ROCHE, R.; MARY, B.; RIPOCHE, D.; ZIMMER, D.; SIERRA, J.; BERTUZZI, P.; BURGER, P.; BUSSIERE, F.; CABIDOCHE, Y.M., CELlIER, P.; DEBAEKE, P.; GAUDILlERE, J.P.; HENAULT, C.; MARAUX, F.; SEGUIN, B.; SINOQUET, H. An overview of the crop model STICS. European Journal Agronomy, v.18, p.309-332.

BRITZ, G.D. The effect of defoliation at various growth stages on maize grain yield. Crop Production, v.11, p.85-89, 1982.

CHATTERTON, N.G., LEE D.R.; HUNGERFORD WE. Diurnal change in specific leaf weihght of Medicago sativa L and Zea mays L. Crop Science, v.12, p.576-578.

CIRILO, A.G.; ANDRADE, F.H. Sowing date and maize productivity: II. Kernel number determination. Crop Science, v.34, p.1044-1046, 1994. 
CIRILO, A.G.; ANDRADE, F.H. sowing date and kernel weight in maize. Crop Science, v.34, p.1039-1043, 1994.

COSTA, L.C. Modelagem e simulação em agrometeorologia. In: CONGRESSO BRASILEIRO DE AGROMETEOROLOGIA, 10, Piracicaba, 1987. Suplemento dos anais. Piracicaba: SBA, 1997. p.3-6.

DANALATOS, N.G.; KOSMAS, C.S.; DRIESSEN, P.M.; YASSOGLOU, N. The change in the specific leaf área of maize grown under Mediterranean conditions. Agronomie, v.14, p.433-443, 1994.

DAYNARD, T.B.; DUNCAN, W.G. The black layer and grain maturity in corn. Crop Science, v.9, p.831-834, 1969.

DAYNARD, T.B.; TANNER, J.W.; HUME, D.J. Contribution of stalk solube carbohydrates to grain yield in corn. Crop Science, v.9, p.831-834, 1969.

DE WIT, C.T. Simulation of living systems. In. PENNING DE VRIES, F.W.T.; VAN LAAR, H.H. (Ed.) Simulation of plant growth and crop production. Wageningen: Pudoc, 1982. p.3-8.

DIAZ, A.C. Influencia de la defoliacion en un hibrido varietal blanco de maiz (Zea mays L.). Revista del Inst. Col. Agropec, v.18, n.1, p.1-8, 1983.

DONALD, C.M. Breeding of crop ideotypes. Euphytica, v.17, n.3, p.385-393, 1968.

DOURADO NETO, D. Balanço hídrico cíclico e seqüencial: estimativa de armazenamento de água no solo. In: CONGRESSO NACIONAL DE IRRIGAÇÃO E DRENAGEM, 11, Título do Congr.; resumos. Campinas, CONIRD,1996, p.3042 .

DOURADO NETO, D. Modelos fitotécnicos referentes à cultura do milho. Piracicaba, 1999. 229p. Tese (Livre-Docência) - Escola Superior de Agricultura "Luiz de Queiroz”, Universidade de São Paulo.

DUVICK, D.N.; COSSMAN, K.G. Post-green revolution trends in yield potencial of temperate maize in the North-Central United States. Crop Science, n.39, p.16221630, 1999. 
DWYER, L.M.; STEWART, D.W. Effect of leaf age and position on net photosynthetic rates in maize (Zea mays, L.). Agricultural and Forest Meteorology, n. 37, p.2946, 1986.

DWYER, L.M.; TOLLENAR, M.; STEWART, D.W. Changes in plant density dependence of leaf photosynthesis of maize (Zea mays, L.) hybrids, 1959 to 1988. Canadian Journal of Plant Science, v.71, p.1-11, 1991.

EDEMEADES, G.O.; BOLANOS, J. Issues arising from the use of CERES for tropical maize. In: Directions in Modeling Wheat and Maize for Developing Countries. Proceedings of the Workshop on CIMMYT, El Batan, México, 4-6 de Maio, 1998. México: CIMMYT. NRG-GIS Serie 01-02. 2001, p.13-17.

EHLERINGER, J.; PEARCY, R.W. Variation in quantum yiled for $\mathrm{CO}_{2}$ uptake among $\mathrm{C}_{3}$ and $\mathrm{C}_{4}$ plants. Plant physiology, v.73, p.555-559, 1983.

EVANS, J.R. Photosynthesis and nitrogen relationships in leaves of $\mathrm{C}_{3}$ plants. Oecologia, n.78, p.9-19, 1989.

FAGERIA, N.K.; BALIGAR, V.C.; JONES, C.A. Growth and mineral nutrition of field crops. $2^{\mathrm{a}}$ ed.New York: Marcel Dekker,, 1997. 624p.

FAGUNDES, A.C. Efeitos da redução da área foliar sobre a produção de milho. Revista da Faculdade de Agronomia, UFRGS, Porto Alegre, v.1, p.79-84, 1976.

FAIREY, N.A.; DAYNARD, T.B. Assimilate distribution and utilization in maize. Canadian Journal of Plant Science, v.58, n.3, p.719-730, 1978.

FANCELLI, A.L. Influência do desfolhamento no desempenho de plantas e sementes de milho (Zea mays L.). Piracicaba, 1988. 172p. Tese (doutorado) - Escola Superior de Agricultura Luiz de Queiroz, Universidade de São Paulo.

FANCELLI, A.L.; DOURADO NETO, D. Produção de milho. Guaíba: Agropecuária, 2000. 360p.

FIELD, C. Allocation leaf nitrogen for the maximization of carbon gain: Leaf age as a control on the allocation program. Oecologia, v.56, p.341-347, 1983.

FLÉNET, F.; KINIRY, J.R.; BOARD, J.E.; WESTGATE, M.E.; REICOSKY, D.C. Row spacing effect on light extinction coefficient of corn, sorghum, soybean, and sunflower. Agronomy Journal, v.88, p.185-190, 1996. 
FNP CONSULTORIA \& AGROINFORMATIVOS, AGRIANUAL 2002. Anuário da agricultura brasileira, São Paulo, 2002, p.417-437 (Milho).

FORNASIERI FILHO, D. Técnica cultural. Jaboticabal: UNESP, Faculdade de Ciências Agrárias e Veterinárias, 2000. 27p.

FRANCIS, C.A.; RUTGER, J.N.; PALMER, A.F.E. A rapid method for plant leaf area estimation in maize (Zea mays L.). Crop Science, v.9, n.5, p.537-539, 1969.

FRATTINI,J.A. Cultura do Milho: instruções sumárias, Campinas: CATI/COT, 1975. 26p. (mimeografado).

FREY, N.M. Dry matter accumulation in kernels of maize. Crop Science, v.21, p.118$122,1981$.

GADIOLI, J.L. Estimativa de produtividade de grãos e caracterização fitotécnica da cultura do milho (Zea mays L.). Piracicaba, 1999. 86p. Dissertação (Mestrado) Escola Superior de Agricultura "Luiz de Queiroz", Universidade de São Paulo.

GMELING MEYLING, H.D. Effect of light intensity and day lenght on the rate of leaf appearance in maize, Netherlands Journal of Agricultural Science, v.21, p.68-76.

GOSSE, G.; VARLET-GRANCHER, C.; BOMHOMME, R.; CHARTIER, M.; ALLIRAND, J.M.; LEMAIRE, G. Maximum dry matter production and solar radiation intercepted by a canopy. Agronomie, n.6, p.47-56, 1986.

GOUDRIAAN, J. A simple and fast numerical method for the computation of daily totals of crop photosynthesis. Agricultural and Forest Meteorology, v.38, p. 249254, 1986.

GOUDRIAAN, J.; VAN KEULEN, H. The direct and indirect effects of nitrogen shortage on photosynthesis and transpiration in maize and sunflower. Netherlands Journal of Agronomy Science, v.27, p. 227-234, 1979.

GOUDRIAAN, J.; VAN LAAR, H.H.. Modelling potential crop growth processes: The textbooh with exercises. Dordrecht: Kluwer, 1994. 239p.

GRANT, R.F. Simulation of carbon assimilation and partitioning in maize. Agronomy Journal, v.81, p.563-571, 1989. 
HAMMER, G.L.; WRIGHT, G.C. A theoretical analysis of nitrogen and radiation effects on radiation use efficiency in peanut. Australian Journal Agricultural Research, v.45, p.575-589, 1994.

HIROSE, T.; WERGER, J.A. Nitrogen use in instantaneous and daily photosynthesis of leaves in canopy of a Solidago altissima stand. Physiological Plantarium, v.70, p.215-222, 1987.

HOOGENBOOM, G. Contribution of agrometeorology to the simulation of crop production and its applications. Agricultural and Forest Meteorology, v.103, p.137-157, 2000.

HSU, F.H. Study on the effects of early defoliation on the agronomic traits of maize (Zea mays L.) under different plant population densities. Journal of the Taiwan Livestock Research, v.11, p.63-71, 1978.

HUNT, R. Plant crowth curves:. the functional aprroach to growth analysis. Edward Arnold: London. 248p.

JACOBS, B.C.; PEARSON, C.J. Pontential yield of maize, determined by rates of growth and development of ears. Field Crops Research, v.27, p.281-298, 1991.

JAME, Y.W.; CUTFORTH, H.W. Crop growth models for decision support systems. Canadian Journal of Plant Science, v.76, p.9-19, 1996.

JOHNSON, D.R.; TANNER, J.W. Calculation of the rate and duration of grain filling in corn (Zea mays L.). Crop Science, v.12, p.485-486, 1972.

JONES, C.A. $\mathbf{C}_{\mathbf{4}}$ grasses and cereals: growth, development, and stress response. New York: Wiley, 1985.

JONES, C.A.; KINIRY, J.R. CERES-Maize: a simulation model de maize growth and development. College Station: Texas A\&M Univ.Press, 1986. 194p.

JONES, J.W.; HOOGENBOOM, G.; PORTER, C.H.; BOOTE, K.J.; BATCHELOR, W.D.; HUNT, L.A.; WILKENS, P.W.; SINGH, U.; GIJSMAN, A.J.; RITCHIE, J.T. DSSAT Cropping system model. European Journal of Agronomy, v.18, p.235-265, 2003.

JONES, R.J. \& SIMMONS, S.R. Effect of altered source-sink ratio on growth of maize kernels. Crop Sciences, v.23, n.1, p.129-134, 1983. 
JONG, S.K.; BREWBAKER, J.L.; LEE, C.H. Effects of solar radiation on the performance of maize in 41 sucessive montly plantings in Hawaii. Crop Science, n.22, p.13-18, 1982.

KHAMIS, S.; LAMAZE, T.; LEMOINE, Y.; FOYER, C. Adaptation of the photosynthetic apparatus in maize leaves as a result of nitrogen limitation. Relationship between electron transport and carbon assimilation. Plant Physiology, V.94, p. 1436- 1443.

KINIRY, J.R. Maize physics development. In: AMERICAN SOCIETY OF AGRONOMY. Modeling plant and soil systems. Madison: ASA, CSSA, SSSA, 1991, p. 55-71. (Agronomy Monographs, 31).

LAMBERS, H. Respiration in intact plants and tissues: its regulation and dependence on environmental factors, metabolism and invaded organisms. In: Enciclopedia of Plant Physiology, New Series (R. Douce and D.A. Day, eds), v.18, p.418-473. Springer - Verlag, Berlin.

LIETH, J.H.; REYNOLDS, J.F. A model of canopy irradiance in relation to changing leaf-area in a phytotron-grown snap bean (Phaseolus vulgaris L.) crop. International Journal of Biometeorology, v.28, n.1, p.61-71, 1984.

LIMA, M.G. Calibração e validação do modelo Ceres-maize em condições tropicais do Brasil. Piracicaba, 1995. 119p. Tese (Doutorado) - Escola Superior de Agricultura “Luiz de Queiroz", Universidade de São Paulo.

LISBOA, J.A.P.; SCOTEGAGNA, G.A.; GOMES, DN. Milho. Revista Genótipo, v.2, p.32-35, 1999.

LIZASO, J.I.; BATCHELOR, W.D.; WESTGATE, M.E.; ECHARTE, L. Enhancing the ability of CERES-Maize to compute light capture. Agricultural Systems, v.76, p.293-311, 2003.

LOOMIS, R.S.; AMTHOR, J.S. Yield potential, plant assimilatory capacity, and metabolic efficiencies. Crop Science, v.39, p.1548-1596, 1999.

LOOMIS, R.S.; CONNOR, D.J. Crop ecology: productivity and management in agricultural systems. Cambridge: Cambridge University, 1992. 550p. 
LOOMIS, R.S.; WILLIAMS, W.A. Productivity and morphology in crop stands: patterns with leaves. In: EASTIN, J.O.; HASKINS, Z.A.; SULLIVAN, O.G.; VAN BASVEL, C.H.M. (Ed). Physiological Aspects of Crop Yields. Madison: American Society of Agronomy, 1969. 230p.

LOPES, N.F.; MAESTRI, M. Crescimento, morfologia, participação de assimilados e produção de matéria seca do milho (Zea mays L.) cultivado em três densidades populacionais. Revista Ceres, v.28, n. 157, p.268-288, 1981.

MAGALHÃES, P.C.; JONES, R. Aumento de fotoassimilados sobre teores de carboidratos e nitrogênio em milho. Pesquisa Agropecuária Brasileira, v.25, p.1755-1761, 1990b.

MAGALHÃES, P.C.; PAIVA, E. Fisiologia da produção de milho. In: EMPRESA BRASILEIRA DE PESQUISA AGROPECUÁRIA. Recomendações técnicas para o cultivo do milho. Brasília:EMBRAPA, SPI. 1993.p.85-92.

MAGALHÃES, P.C; JONES, R. Aumento de fotoassimilados na taxa de crescimento e peso final dos grãos de milho. Pesquisa Agropecuária Brasileira, v.25, p.17471754, 1990a.

MEDLYN, B.; BARRETT, D.; LANDSBERG, J.; SANDS, P.; CLEMENT, R. Conversion of canopy intercepted radiation to photosynthate: review of modelling approaches for regional scales. Functional Plant Biology, v.30, p.153-169, 2003.

MOCK, J.J.; PEARCE, R.B. An ideotype of maize. Euphytica, n.24, p.613-623, 1975.

MONTHEITH, J.L. Climate and the efficiency of crop production in Britain. Transaction Royal Society of London Botany. v.281, p.277-294, 1977.

MONTHEITH, J.L. The quest balance in crop modeling. Agronomy Journal, v.88, p.695-697, 1996.

MUCHOW, R.C. Efecct of high temperature on grain-growth in field-grow maize. Field Crops Research, v.23, p.145-158, 1990.

MUCHOW, R.C. Effects of leaf nitrogen and water regime on the photosynthetic capacity of kenaf (Hibiscus cannabinus,L.) under field conditions. Australian Journal of Agricultural Research, n.41, p.845-852, 1990. 
MUCHOW, R.C.; DAVIS, R. Effect of nitrogen suplly on the comparative productivity of maize and sorghum in a semi-arid tropical environment. II. Radiation interception and biomass ccumulation. Field Crops Research, v.18, p.17-30, 1988.

MUCHOW, R.C.; SINCLAIR, T.R. Nitrogen response of leaf photosynthesis and canopy radiation use efficiency in field-grown maize sorghum. Crop Science, v.34, p.721-727, 1994.

MUCHOW, R.C.; SINCLAIR, T.R., BENNETT, J.M. Temperature and solar radiation effects on potential maize yields across locations. Agronomy Journal, v.82, p.338$342,1990$.

MUNAKATA, K. Simulation of population photosynthesis and dry matter production. In MATSUO, T.; KUMAZAWA, K. ISHII, R.; ISHIHARA, K.; HIRATA, H. (Ed.) Science of the rice plant, 1995, v.2, p.671-684. (Physiology, Food and Agricultural Policy Research Center).

NOBEL, P.S. Physicochemical and Environmental Plant Phisiology. São Diego: Academic Press. 250p.

NOBEL, P.S.; FOESETH, I.N.; LONG, S.P. Canopy structure and light interception. In: HALL， D.O.; SCURLOCK， J.M.O.; BOLHÀR-NORDENKAMPF， H.R.; LEEGOOD, R.C.; LONG, S.P. (Ed). Photosynthesis and production in a changing environment: a field and laboratory manual. London: Chapman \& Hall, 1993. p.79-90

NORMAN, J.M.; CAMPBELL, G.S. Interfacing leaf and canopy light interception models. In: PEARCY, R.W.; EHLERINGER, J.R.; MOONEY, H.A.; RUNDEL, P.W. (Ed). Plant physiological ecology. Field Methods and Instrumentation. New York: Chapman and Hall, 1989. p.301-325.

NUNES, F.C.F. de P. Relações entre irregularidades pluviométricas, desenvolvimento fenológico e produtividade do milho (Zea mays L.) e probabilidade de frustração de safra. 147p., Fortaleza, 1993, Dissertação (Mestrado) - Universidade federal do Ceará.

OMETTO, F.C.F. Bioclimatologia vegetal. São Paulo: Ceres, 1981, 440p. 
PALHARES, M. Distribuição e população de plantas e produtividade de grãos de milho. 90p., Piracicaba, 2003, Dissertação (Mestrado) - Escola Superior de Agricultura “Luiz de Quiroz”, Universidade de São Paulo.

PATTEY, E.; ROCHETTE, P.; DESJARDINS, R.L.; DUBÉ, P.A. Estimation of net $\mathrm{CO}_{2}$ assimilation rate of a maize (Zea mays L.) canopy from leaf chamber measurements. Agricultural and Forest Metereology, v.55, p.37-57, 1991.

PEARCE, R.B.; BROWN, R.H.; BLASER, R.E. Photosynthesis in plant communities as influenced by leaf angle. Crop Science, n.7, p.321-324, 1967.

PEARSON, C.J.; LARSON, E.M.; HESKETH, J.D.; PETERS, D.B. Development and source-sink effects on single leaf and canopy carbon dioxide exchange in maize. Field Crops Research, v.9, n.5, p. 391-402, 1984.

PENNING DE VRIES, F.W.T. The cost of maintenance processes in plant cells. Annals of Botany, v.39, p.77-92, 1975

PEREIRA, P.A.A.; BALDANI, J.I., BLAÑA, R.A.G.; NEYRA, C.A. Assimilação e translocação de nitrogênio em relação à produção de grãos e proteínas em milho (Zea mays L.). Revista Brasileira de Ciência do Solo, n.5, p.28-31, 1981.

PINTER, L.; KALMAN, L. Effects of defoliation on loading and yield of maize hybrids. Experimental Agriculture, v.15, p.241-245, 1979.

PONS, T.L.; SCHIEVING, F.; HIROSE, T.; WERGER, M.J.A. Optimisation of leaf nitrogen allocation for canopy photosynthesis in Lysimachia vulgaris L.. In: LAMBERS, H.; CAMBRIDGE, M.L.; KONINGS, H.; PONS, T.L. (Ed) Causes and consequences of variation in growth rate and productivity of higher plants. The Hague: SPB Academic Publishing, 1989. p.175-186

RODRIGUES, O.; DIDONET, A.D. Milho: efeito da temperature na duração e na taxa de crescimento de grãos. Embrapa-trigo, Boletim de pesquisa e desenvolvimento n.15, 2003.

ROSS, J. The radiation regime and architecture of plant stands. Hague: Dr. W. Junk, 1981. $240 \mathrm{p}$ 
RUGET, F.; ANDRÉ, M.; MASSIMINO, J. Evolution de la respiration et croissance, an cours d'un cycle de vegetation de mais cultivé en chamber de mesure. Physiologie Végétale, v.19, n.2, p. 227-229, 1981.

SANDS, P.J. Moddelling canopy produtction. III - Canopy light-utilisation efficiency and its sensitivity to physiological and environmental variables. Australian Journal Plant Physiology, n.23, p.103-114, 1996.

SANGOI, L.; GRACIETTI, M.A.; RAMPAZZO, C.; BIANCHETTI, P. Response of brazilian maize hybrids from different eras to changes in plant density. Field Crops Research, v.79, p.39-51, 2002.

SANGOI, L.; SALVADOR, R.J. Influence of plant height and leaf number on maize production at high plant densities. Pesquisa Agropecuária Brasileira, n.33, p.297306, 1998.

SHAW, R.H. Climatic requirements. In: Corn and corn improvement. Madison: Wisconsin, American Society of Agronomy, Publisher, 1977. p.591-623 (Serie Agronomy, 18).

SIVAKUMAR, M.V.K.; VIRMANI, S.M. Crop productivity in relation to interception of photosynthetically active radiation. Agricultural and Forest Meteorology, v.31, p.131-141, 1984.

SINCLAIR, T.R. Historical changes in harvest index and crop nitrogen accumulation. Crop Science, v.38, n.2, p.638-643, 1998.

SINCLAIR, T.R.; BENETT, J.M.; BOOTE, K.J. Nitrogen content, photosynthesis and radiation use efficiency in peanut. Peanut Science, n.20, p.40-43, 1993.

SINCLAIR, T.R.; HORIE, T. Leaf nitrogen, photosynthesis, and crop radiation use efficiency: A review. Crop Science, v.29, p.90-98, 1989.

SINCLAIR, T.R.; MUCHOW, R.C. Radiation use efficiency. Advances in Agronomy, v.65, p.215-265, 1999.

SINCLAIR, T.R.; MURPHY, C.E. Junior.; KNOERR, K.R. Development and evaluation of simplified models for simulating canopy photosynthesis and transpiration. Journal Application Ecology, v.13, p.813-839, 1976. 
SINGH, B.S. Modeling photosynthesis and carbon partitioning: Introduction to the workshop. Hortscience, v.29, n.12, p.1412-1413, 1994.

SIVAKUMAR, M.V.K.; VIRMANI, S.M. Crop productivity in relation to interception of photosynthetically active radiation. Agricultural and Forest Meteorology, n.31, p.131-141, 1984.

SPITTERS, C.J.T. Separating the diffuse and direct component of global radiation and its implications for modelling canopy photosynthesis. Part II. Calculation of canopy photosynthesis. Agricultural and Forest Meteorology, v.38, p. 231-242, 1986.

STEWART, D.W.; DWYER, L.M. Mathematical characterization of leaf shape and area of maize hybrids. Crop Science, n.39, p.422-427, 1999.

STÖCKLE, C.; DONATELlI, M.; NELSON, R. CropSyst, a cropping systems simulation model. European Journal Agronomy, v.18, p.289-307.

THIAGARAJAH, M.R.; HUNT, L.A.; MAHON, J.D. Effects of position and age on leaf photosynthesis in corn (Zea mays). Canadian Journal Botany, v.59, p.28-33, 1981.

THOMAS, H.; STODDART, J.L. Leaf senescence. Annual Review of Plant Physiology, v. 31, p.83-111.

THORNLEY, J.H.M. Mathematical models in plant physiology: a quantitative approach to problems in plant and crop physiology. London: Academic Press, 1976. $318 \mathrm{p}$.

TOJO SOLER, C.M. Uso do modelo Ceres-Maize para previsão do milho "safrinha". Piracicaba, 2004. 132p. Tese (doutorado) - Escola Superior de Agricultura Luiz de Queiroz, Universidade de São Paulo.

TOLLENNAAR, M; AHMADZADEH, A.; LEE, E.A. Physiological basis of heterosis for grain yield in maize. Crop Science, v.44, p.2086-2094, 2004.

TOLLENAAR, M. \& DAYNARD, T.B. Effect of defoliation on kernel development in maize. Canadian Journal of Plant Science, v.58, p.207-212, 1978.

TOLLENAAR, M. Is low plant density a stress in maize? Maydica, n.37, p.305-311, 1992. 
TOLLENAAR, M. Sink-source relationship during reproductive development in maize: a review. Maydica, v.22, p.49-75, 1977.

TOLLENAAR, M.; AGUILERA, A.; NISSANKA, S.P. Grain yield is reduced more by weed interference in an old than in a new maize hybrid. Agronomy Journal, n.89, p.239-246, 1997.

TOLLENAAR, M.; WU, J. Yield improvement in temperate maize is attributable to greater stress tolerance. Crop Science, n.39, p.1597-1604, 1999

TSAI, C.L. Partitioning efficiency in cereal crops. Field Crops Abstracts, 1982.

VAN ITTERSUM, M.K.; LEFFELLAAR, P.A.; VAN KEULEN, H.; KROPFF, M.J.; BASTIAANS, L.; GOUDRIAAN, J. On approaches an applications of the Wageningen crop models. European Journal Agronomy, v.18, p.201-234, 2003.

VAN KEULEN, H.; GOUDRIAAN, J.; SELIGMAN, N.G. Modelling the effects of nitrogen on canopy development and crop growth. In: RUSSEL, G. (Ed.) Plant canopies and their growth, form and function, Cambridge: Cambridge University Press, 1989. p.83-104.

VASILAS, B.L.; SEIF, R.D. Pré-anthesis defoliation effects on six corn inbreds. Agronomy Journal, v.77, p.831-835, 1985.

VILA NOVA, N.A.; PEDRO JÚNIOR, M.; PEREIRA, A.R.; OMETTO, J.C. Estimativa de graus-dia acumulados acima de qualquer temperatura base, em função das temperaturas máxima e mínima. Cadernos de Ciências da Terra, n.30, 1972. 8p.

VILLANUEVA, J.G. Estudo do coeficiente de transferência do vapor d'água sobre a cultura do feijão. Piracicaba, 1987. 58p., Dissertação (Mestrado) - Escola Superior de Agricultura "Luiz de Queiroz", Universidade de São Paulo.

WERGER, M.J.A.; HIROSE, T. Leaf nitrogen distribution and whole canopy photosynthetic gain in herbaceous stands. Vegetatio, n.97, p.11-20, 1991.

WILLIAMS, L.E. Net photosynthetic rate and stomatal and intracellular condutances subsequent to full leaf expansion in Zea mays L.: Effect of leaf position. Photosynthetica, v.19, n.3, p.397-401, 1985.

WISLIE, C.P. Crop adaptation and distribution. São Francisco: W. H. Freeman and Company, 1962. 448p. 
WRIGHT, G.C.; BELL, M.J.; HAMMER, G.L. Leaf nitrogen content and minimum temperature interactions affect radiation use efficiency in peanut. Crop Science, v.33, p.476-481, 1993.

WRIGHT, G.C.; HAMMER, G.L. Distribution of nitrogen content and minimum temperature interactions affect radiation use efficiency in peanut canopies. Australian Journal Agricultural Research, v.45, p.565-574, 1994.

YANG, H.S.; DOBERMANN, A.; LINDQUIST, J.L., WALTERS, D.T., ARKEBAUER, T.J.; CASSMAN, K.G. Hybrid-maize - a maize simulation model that combines two crop modeling approaches. Field Crops Research, v.87, p.131154, 2004. 